UC-NRLF

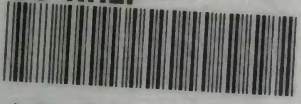

\$ D $14 \quad 500$

\author{
T115: \\ FLORA
}

OF HARROW 


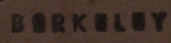 LIBRARY UNIVERSITY OP CALIPORNIA}

\section{BIOLOEY LIBRARY}




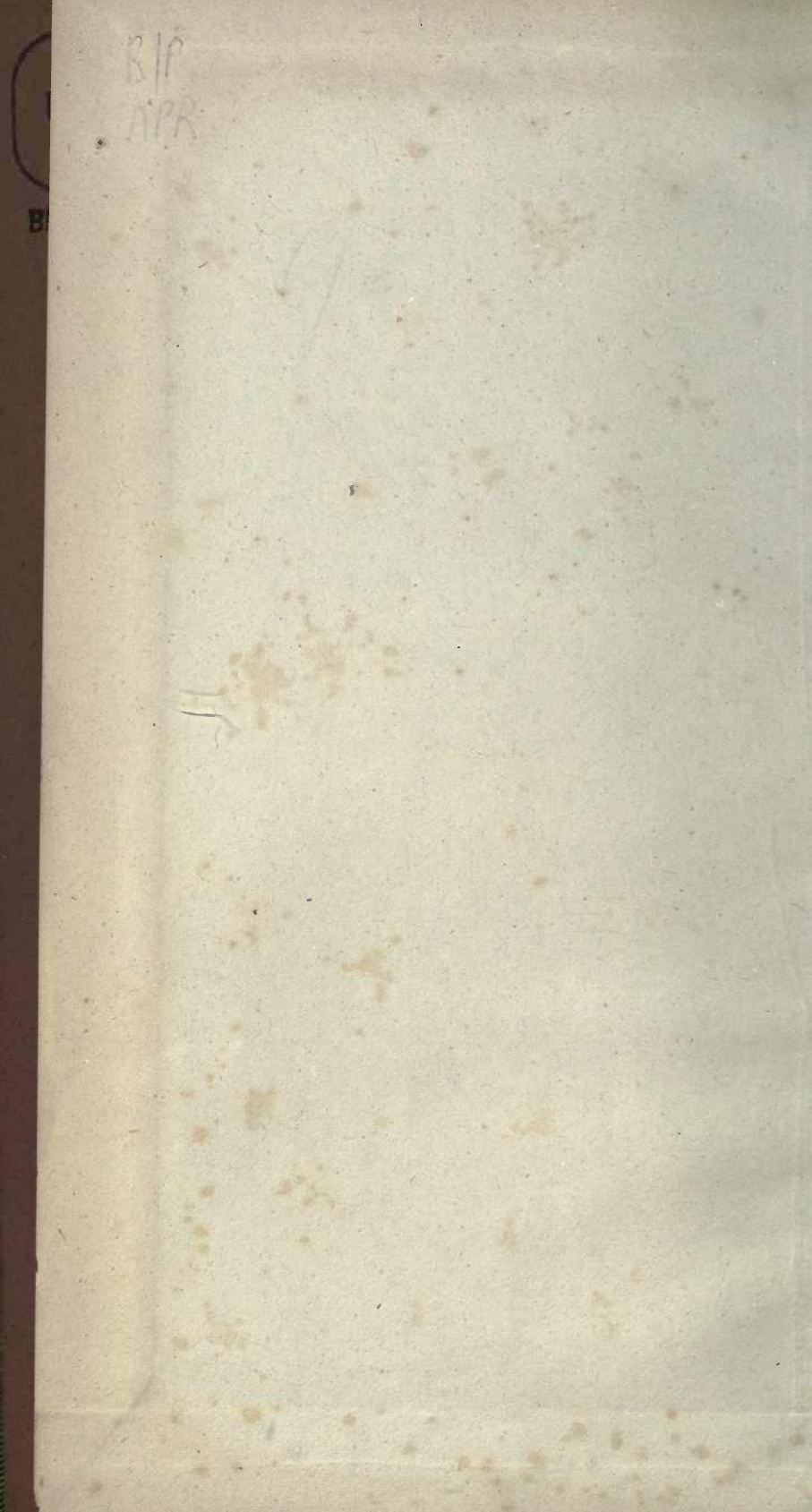




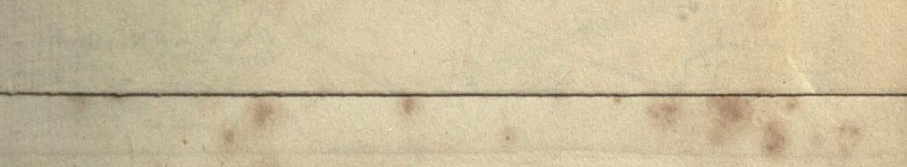

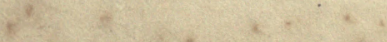




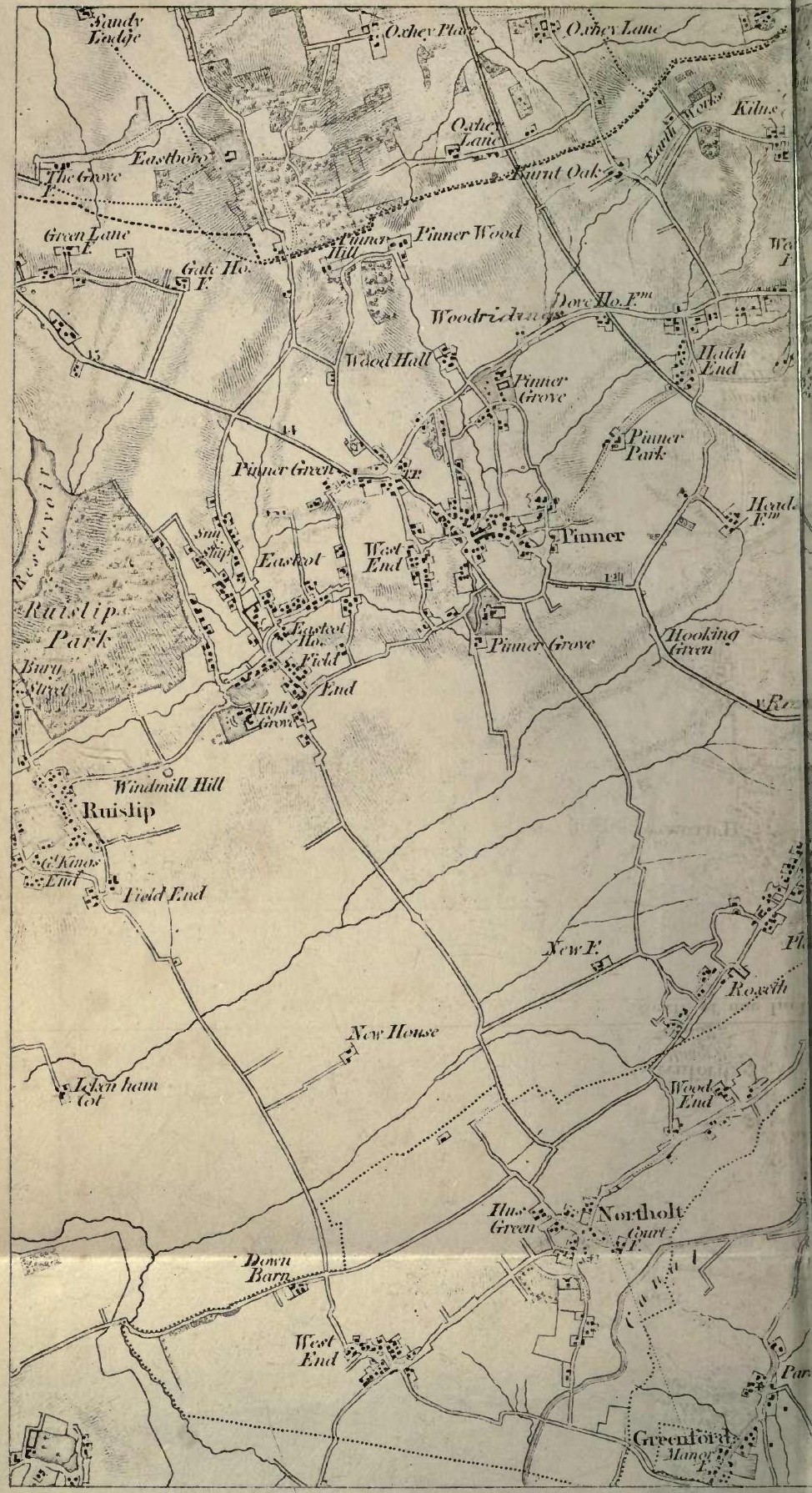




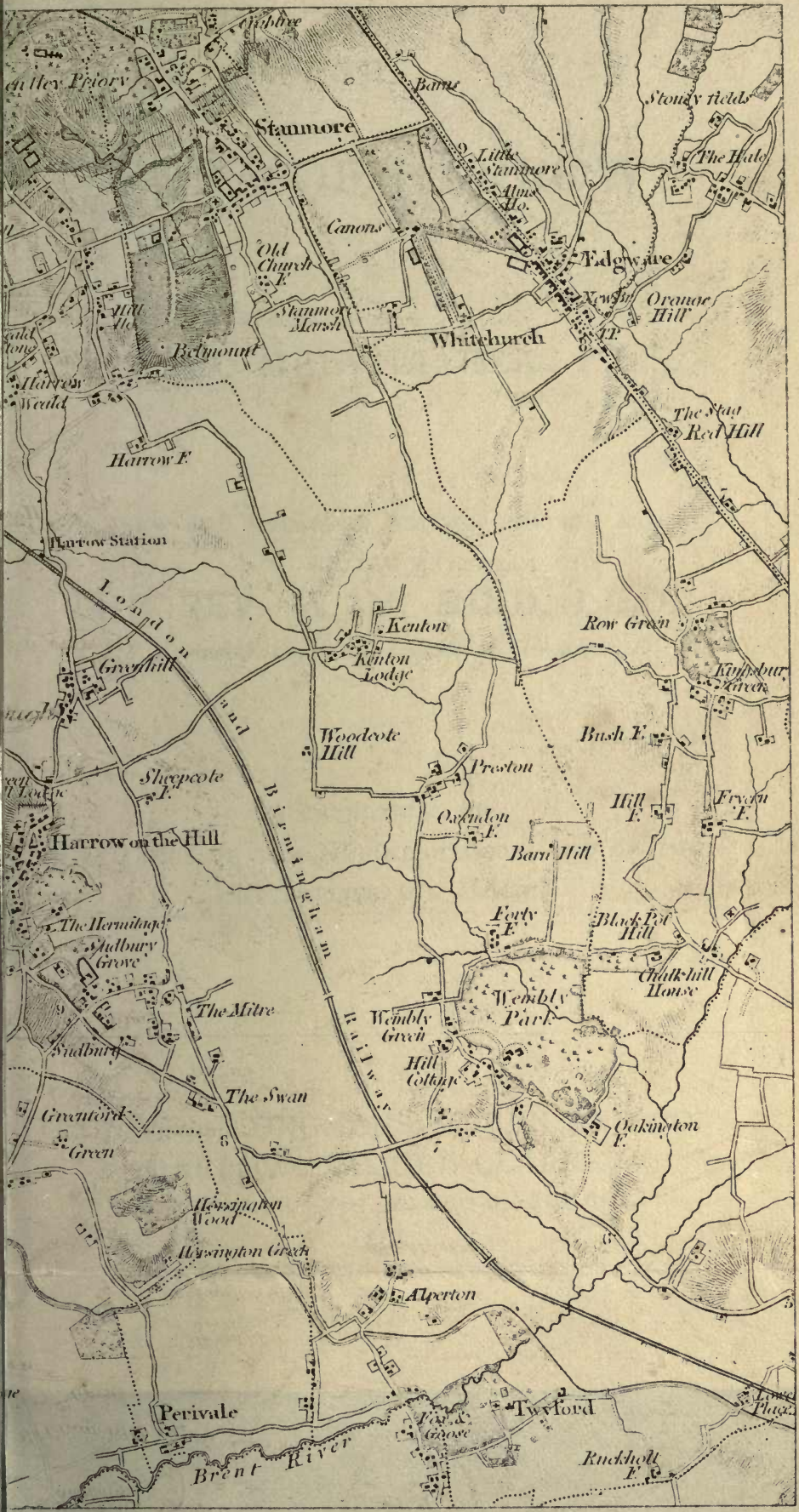





\section{THE}

\section{FLORA OF HARROW :}

BY

J. COSMO MELVILL, M.A., F.L.S.

A NEW AND ENLARGED EDITION REVISED AND EDITED BY

THE REV. W. M. HIND, LL.D., Formerly Perpetual Curate of Pinner.

WITH NOTICES OF

The Birds of the Neighbourhood, AND of the Butterflies AND Moths.

LONDON : LONGMANS, GREEN AND CO. HARROW: SAMUEL CLARKE, BOOKSELLER TO HARROW SCHOOL. 1876. 


\section{BIOLOGY}

\section{ADDENDA.}

After Reseda luteola, p. 12, insert:

R. alba.* L. (White Mignonette.)

Waste and sandy places, usually near the sea. $5-9$.

Rare. Accidentally introduced. Pinner Parsonage Garden, where it appeared several years in succession.

After $P$. vulgaris, on p. 82 :

Primula elatior. Jacq. (Jacquin's, or True Oxlip.)

Woods and meadows. 4,5 .

Wood End, Ruislip; Hope Cottage Farm and Terrilands, Pinner. This plant has little chance of permanently asserting its claims as a native of the district; as when found it is usually transferred to the garden, or carried off to London by the plant grubbers, who are quickly exterminating the Primrose tribe and Ferns throughout Middlesex.

Add to Listera Nidus avis, p. 98, the new station, Pinner Hill. (IV. A. Tooke, Esq.) 


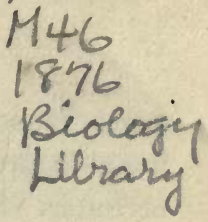

PREFACE TO THE FIRST EDITION.

The little work now presented to the reader has been entirely drawn up by Harrow boys, of whom four are still members of the school, and one has recently left it. The very full and interesting account of the Flora of Harrow, including the Ferns and Grasses, has been written by Mr. J. C. Melvill; the notices of the Birds were furnished by the Honbles. F. C. and G. O. M. Bridgeman; and the list of Butterflies was drawn up from the joint observations of Mr. C. C. Parr and Mr. F. Heathfield. The publication of the book has solely arisen from a very strong desire to promote at Harrow an interest in Natural History, and to furnish our young naturalists with the permanent record of previous investigations, which have supplied a happy and innocent occupation to some of their contemporaries.

It may seem a very simple and commonplace task to draw up such lists as these; nevertheless to do so with any accuracy requires an earnest and long-continued research, and it is hoped that by indicating the localities where so many of the rarest flowers, birds, butterflies, and moths may be discovered, our youthful authors have saved much trouble and disappointment to future collectors. And aithough the sketches presented in the following 
pages cannot pretend to completeness, they may prove useful in preparing the way for some more perfect work hereafter. Such a work - which would be both useful and interesting,-will be greatly facilitated if any Harrovian interested in Natural History will be so good as to furnish us with details of any observations not noticed by those whose researches are here placed at the disposal of the inhabitants and of the school.

It must be admitted that at first sight Harrow does not appear to offer to the botanist a favourable scene for his pursuits. We have here little or no variety of soil, and little or no variety of cultivation. The combination of clay, and pasture land, has not much to provide in the shape of an interesting flora, and most of our rarest plants are not to be obtained without the trouble of walking sume miles to find them. A few indeed occur in Harrow Park, in the Grove, and on the Railway Embankment; but the collector will obtain but a poor herbarium unless he be content to stroll at least as far as Horsington Lane, the Greenford Canal, and the Pinner Drives. To get at the choicest botanical hunting-fields he must prolong his walks to Pinner and Oxhey Woods, to the Ruislip Reservoir, to the banks of the River Brent, and above all to Harrow Weald Common, at which place his diligence cannot fail to be well rewarded. It happens unfortunately that even in these places our chief treasures are both extremely local, and very sparsely scattered; we cannot therefore refrain from expressing our earnest hope that no Harrovian will ever give way to that botanical greed which has led so many botanists to extirpate in many parts of England our most unfrequent and interesting varieties. We fear that the caution is 
only too much needed, since already one of our handsomest flowers,--the Geranium Phaum, or Dusky Crane's Bill,-has disappeared, or nearly so, from a habitat in which we had discovered it some three years ago; and we could name several other flowers which are incurring a similar peril. We hear that, among others, a London Botanist has even made a raid on the beautiful but rare Fritillarias which lend such interest to one or two localities in the neighbourhood of Pinner. We cannot avoid these depredations, but we hope that every Harrovian who studies botany may be so much impressed with the injury done to any neighbourhood by extirpating one of its scarce plants, that he would forego any specimen, however choice, rather than run the risk of giving a flower no chance of fairly establishing itself. The spirit of the same remark applies with at least equal force to the practice of robbing the nests of our rarer birds. Much might be done to preserve these interesting visitors if we were only content to treat them with a little more hospitality; and no one can pretend to a real love for Natural History unless he does his best to suppress that ruthless and wholesale robbery of nests which is systematically carried on by some boys of the neighbourhood. If it continues we shall soon lose from Harrow even the Nightingales which now furnish one of the most delightful enjoyments of our summer days.

F. W. F.

Harrow, June, 1864. 
PREFACE TO THE SECOND EDITION.

During the twelve years which have elapsed since the first edition of this Flora was published, considerable progress has been made towards a fuller knowledge of the Botany of Harrow and its neighbourhood. Between 1864 and 1869, when the Flora of Middlesex was published, several plants of interest were found, the Rev. Dr. Farrar being one of the principal discoverers. The results of these discoveries are recorded in this latter work. Its Authors, Dr. Trimen and Professor W. Thiselton Dyer, have largely contributed to a full and accurate knowledge of the botany of the district. New plants have been added, new localities noted, the researches of other botanists investigated and set down; a few errors in the former edition of this work have been brought to light, while its general correctness has been confirmed. Free use has been made in this edition of the hoarded wealth of the "Flora of Middlesex," and the Editor gratefully acknowledges the ample return received for any assistance rendered to its Authors, either by himself or by the first edition of this work. 
Since the publication of the "Flora of Middlesex," seventeen new plants have been added to the Harrow Flora. Thirteen of these have been contributed by the Editor, of which Pyrola minor, L., Juncus diffusus, Hoppe, and Cystopteris fragilis are new to the county. W. A. Tooke, Esq., has added Helianthemum vulgare, Gærtn., and Habenaria viridis, R. Br. both to the local and county Flora. The Rev. E. Brewer has fortunately rediscovered Litorella lacustris, L., and so restored to the county a plant supposed to have been lost. Mr. Gunn and others have added to our knowledge of already recorded plants, by the mention of new sites. The Editor returns his grateful acknowledgments to all who have assisted in bringing the knowledge of the local Flora to its present advanced state.

The district comprised in this Flora is slightly within the limits of the map, except on the north-east, where it somewhat exceeds the boundaries of the map, so as to take in the whole of Harrow Weald and Stanmore Parishes. The county boundary is the northern limit of the district. A few plants occurring between this limit and the Colne are given in an Appendix.

The Preface to the First Edition, written by the Rev. Dr. Farrar, is given in part only, the last clause being inapplieable to this present Edition.

Lists of the ascertained Charæ, Mosses and Liverworts of the Harrow district have been inserted. Sufficient attention has not been given to the Lichens and Fungi to make it desirable to set down those that are known; as meagre lists would necessarily be disappointing to all who might desire information with respect to them.

It has been a source of much personal regret to the 
Author, that, since the time he left the School in July, 1864, he has been but rarely able to revisit Harrow, and then under such circumstances only as did not admit much, if any, scope for Botanical research. His want of opportunity has, however, been more than counterbalanced by the most valuable co-operation of the Editor.

Honington, September 1, 1876. 


\section{THE HARROW FLORA.}

\section{CLASS I.}

DICOTYLEDONOUS OR EXOGENOUS PLANTS.

SUb-Class I. THALAMIFLORA.

Order I. RaNUNCUlaCE A. (Crowfoot Tribe.)

[ The numbers in the descriptions indicate the months during which the plant is in flower.]

\section{CLEMATIS. (Clematis.)}

I. C. Vitalba. L. (Traveller's Joy. Wild Clematis.) Hedges in a chalky soil. Shrub. 7-9.

Not common; hedges at Pinner; particularly at Wood Hall, on the Station Road. Horsington Hill. (Flor. Midd.)

\section{ANEMONE. (Wind Flower.)}

r. A. nemorosa. L. (Wood A. Wind Flower.) Moist woods and fields. 4, 5 . Abundant in a field at Roxeth; woods at Stanmore, 
Eastcott, and meadows, Pinner. Plants with crimson petals occur in the Park of Bentley Priory.

[2. A. apennina, L. or Blue Mountain Anemone, is stated by Hooker and Arnott (edition viii. p. 6), to grow "near Harrow," but we are unacquainted with the locality, even if it be still found here.]

\section{MYOSURUS. (Mouse-tail.)}

I. M. minimus. L. (Common Mouse-tail.)

Corn-fields and waste places. 4-6.

A single plant was found by the Rev. F. W. Farrar in the waste ground at Pinner Drive. Perivale. (Flor. Midd.)

\section{RANUNCULUS. (Crowfoot.)}

I. R. Drouetii. Schultz.

Ponds and ditches. 4-6.

Not infrequent. Greenford; Woodridings, Pinner; Ruislip. (Flor. Midd.) (Likely a form of R. heterophyllus, Bab. Man. (Rev. W. W. Newbould.)

2. R. peltatus. Fries (Syme). (Water Crowfoot.)

Ponds and streams. 4-6.

Frequent. Variable. R. aquatilis, L. of edition i. with forms there mentioned are here included.

$R$. fluitans of edition $i$. is the form R. pseudo-fluitans, Syme. (Flor. Nidd.)

\section{R. circinatus. Sibth. (Rigid-leaved Water C.)}

Ponds and ditches. 6, 7 .

Rare? Brook on the Pinner Road (leaves hair-like, rounded, and rigid).

4. R. hederaceus. L. (Ivy-leaved Crowfoot.)

Wet places. 5-8. 
Not common. Harrow Weald Common, and abundant in ditch on the Harrow Weald Road, Hatchend, Stanmore Heath, and Eastcott. (Flor. Midd.)

5. R. sceleratus. L. (Celery-leaved Crowfoot.)

Ditches and muddy ponds. 6-9.

Of frequent occurrence. Especially abundant by the canal at Greenford; accidentally omitted in edition i.

6. R. Flammula. L. (Lesser Spearwort.)

Ditches and marshy ground.

Harrow Weald Common, abundant; occasionally seen at Harrow, but not frequent there. Eastcott, (Flor. Midd.)

7. R. Ficaria. L. (Pilewort. Lesser Celandine.)

Woods and pastures. 3-5.

Everywhere abundant. One of the earliest springflowers.

8. R. auricomus. L. (Wood C. Goldilocks.)

Woods. 4, 5.

Commonly distributed.

9. R. acris. L. (Upright Meadow C.)

Meadows. 6, 7 .

Very common. This and the two next species are commonly known by the name of "Buttercups."

то. R. repens. L. (Creeping C.)

Pastures and meadows. 5-7.

Abundant. I once found a double variety by the Northwick Walk, Harrow, in 1861, but the walk has been altered, and the plants destroyed. Double varieties have also been found in the Football Field. (Edition i.)

II. R. buibosus. L. (Bulbous C.)

Fields. 5,6 . 
Very common. Distinguished from the two former by its reflexed calyx and bulbous root.

I2. R. arvensis. L. (Corn C.)

Corn-fields. 5-7.

Corn-fields at Stanmore, Greenford (abundant). I have observed it sparingly in the waste ground at Headstone Drive. (Edition i.)

CALTHA. (Marsh Marigold.)

I. C. palustris. L. (Common Marsh Marigold.) Marshy places. 3-6. At Pinner, certainly introduced there. In moist pastures at Ruislip, native.

HELLEBORUS. (Hellebore. Bear's-foot.)

I. H. viridis. L. (Green Hellebore.)

Thickets on chalky soil. 2-4.

Down Barn Hill, Northolt (J. Woods).

Order II. Berberidace

\section{BERBERIS. (Barberry.)}

I. B. vulgaris.* L. (Common Barberry.)

Woods and hedges. Shrub. 5. 6.

In the Grove, Harrow, probably planted; a small shrub of it also in Greenford Churchyard. (Edition i.) Cultivated at Pinner.

In a hedge at Eastcott (Rev. E. Brewer). 
Order III. NYMPHÆACE $\approx$. (WATER-LiLy Tribe.)

\section{NYMPHÆA. (Water-Lily.)}

I. N. alba.* L. (White Water-Lily.)

Lakes and ponds. 7.

Pond at Roxeth, destroyed since 1864. I have seen it also at Northolt. (Edition i.) Pinner Hill, introduced.

\section{NUPHAR. (Yellow Water-Lily.)}

I. N. lutea. Sm. (Yellow Water-Lily.)

- Rivers and lakes. 7.

Canal, Lake at Harrow Park (planted), abundant in the River Brent.

Order IV. Papaverace

\section{PAPAVER. (Poppy.)}

I. P. dubium. L. (Long Smooth-headed Poppy.)

Cornfields, old walls and waste places. 5-7.

a. P. Lamottei. Bor.

Old walls and sandpits, Pinner; the more common form at Harrow.

ß. P. Lecoquii. Lamotte. Very rarely at Harrowmore frequent at Pinner.

2. P. Rhæas. L. (Common Red Poppy.) Corn-fields and waste places. Flowers all the summer. On waste heaps, etc., common.

B 2 
3. P. somniferum.* L. (White Poppy.)

Waste ground, usually an escape from cultivation. 7 . Waste heaps at Harrow and Pinner.

\section{GLAUCIUM. (Horned Poppy.)}

I. G. phœniceum.* Crantz. (Scarlet Horned Poppy.) Appeared spontaneously and unaccountably at Pinner in the Parsonage garden in 1865.

\section{CHELIDONIUM. (Celandine.)}

I. C. majus. L. (Common Celandine.)

Waste places near houses. 5-8.

On the Greenford Road, near the Canal Bridge; and hedges at Pinner; Eastcott (Rev. E. Brewer).

\section{MECONOPSIS. (Welsh Poppy.)}

I. M. cambrica.* Vig. (Common Yellow Welsh Poppy.)

Shady or rocky places. 6,7 .

Questionably naturalized at Pinner, where it is found in a few of the cottage gardens.

Order V. FUMariace E. (Fumitory Trire.)

\section{FUMARIA. (Fumitory.)}

I. F. officinalis. L. (Common Fumitory.)

Dry fields and road sides. Flowers through the summer.

Rare. I have only found this plant, so common elsewhere, in the waste clay pits at Harrow Weald. (Edition i.) 
2. F. capreolata. L. (Rampant Fumitory.)

Cultivated ground and hedges. 6.

$F$. pallidiflora. Jord. Harrow.

\section{CORYDALIS. (Corydalis.)}

I. C. lutea.* DC. (Yellow Fumitory.)

Old Walls. 5-8.

Abundant on a wall at Miss Hill's, above the Cricket Field, Harrow, but evidently escaped from cultivation.

Pinner Place, cultivated.

Order Vi. Crucifere. (Cruciferous Tribe.)

\section{CHEIRANTHUS. (Wall Flower.)}

r. C. Cheiri.* L. (Common Wall Flower.)

Old Walls. 5,6 .

One plant was found on Miss Hill's garden wall, like the Corydalis, an evident escape from the garden.

\section{BARBAREA. (Winter Cress.)}

I. B. vulgaris. Br. (Common Winter Cress. Yellow Rocket.)

Hedges and pastures. 5-8.

Commonly distributed.

In the variety $B$. arcuata (Reich.), the petals are twice as long as the calyx. It is found at Roxeth.

2. B. præcox. Br. (Early Winter Cress.)

Waste places. 5-10.

Waste ground at Alperton, near the Canal Bridge there abundant; I also found a single plant near Northolt; (edition i.) occurs at Roxeth and Pinner. 


\section{CARDAMINE. (Bitter Cress.)}

I. C. amara. L. (Large-flowered Bitter Cress.) Wet meadows. 4-6.

Side of Canal at Greenford.

2. C. pratensis. L. (Cuckoo Flower. Ladies' Smock.) Meadows. 4-6.

Everywhere abundant.

3. C. hirsuta. L. (Hairy Bitter Cress.) Moist places. 4-9.

a. C. sylvatica. Link. C. flexuosa. With. Pinner, Harrow Weald; Eastcott, Stanmore. (Flor. Midd.)

ß. C. hirsuta. L. (Bab.) Harrow Weald, Pinner and Ruislip; near Stanmore Church. (Flor. Midd.)

\section{NASTURTIUM. (Watercress.)}

I. N. officinale. Br. (Common Watercress.)

Brooks and rivulets. 5-9.

Canal, frequent; ditch at Kenton, and various other places, but not occurring in great plenty.

2. N. terrestre. Br. (Marsh Yellow Cress.)

Damp places. 6-9.

At Ruislip, abundant in a ditch near the Common: ditch at Headstone, wet ground at Harrow Weald, and near Eastcott; Woodridings, Pinner, in tolcrable plenty. Stanmore Heath. (Flor. Midd.)

3. N. amphibium. Br. (Amphibious Cress. Great Water Radish.)

Watery places. 6-9.

Canal at Greenford. 
4. N. sylvestre. Br. (Creeping Yellow Cress.)

Watery places. 6-8.

Rare. Wet ground at Ruislip, Eastcott; Moss Lane, Pinner. (Flor. Midd.)

\section{ARMORACIA. (Horse Radish.)}

I. A. rusticana.* Baumg. (Common Horse Radish.) Waste ground, near water. 5,6 .

Grove pond, Harrow, waste ground by Peterborough Road, and by the side of a stream at Alperton; chalk pit, Pinner, Stanmore Heath. (Flor. Midd.)

\section{DRABA. (Whitlow Grass.)}

I. D. verna. L. (Common Whitlow Grass.)

Walls and dry banks. 3-5.

Dry pastures at Horsington; Woodhall, Pinner. Stanmore. (Flor. Midd.)

\section{HESPERIS. (Dame's Violet.)}

I. H. matronalis.* L. (Common Dame's Violet.) Pastures and woods, always escaped from cultivation. 5-7.

Near Harrow Weald (Ed. i.) May 24th, 1863; the Parsonage, Pinner : first appeared in 1867.

\section{SISYMBRIUM. (Hedge Mustard:)}

I. S. officinale. Scop. (Common Hedge Mustard.) Waste places and by way sides. 6,7 .

Everywhere abundant.

2. S. thalianum. Hook. (Common Thale Cresss.) Dry banks. 4-7. 
Banks and old walls at Ruislip. Headstone, Pinner. This species is sometimes called Arabis Thaliana. L.

\section{ALLIARIA. (Garlic Mustard.)}

I. A. officinalis. DC. (Garlic Hedge Treacle Mustard. Jack by the Hedge. Sauce alone.)

Hedge banks and waste places. 5-7.

Common. The whole plant smells like garlic, hence its name.

ERYSIMUM. (Treacle Mustard.)

I. E. cheiranthoides. L. (Worm-seed Treacle Mustard.)

Gardens and waste places. 6-8.

Corn-fields at Wood End. The Circuits, Pinner.

\section{CAPSELLA. (Shepherd's Purse.)}

I. C. Bursa pastoris. DC. (Common Shepherd's Purse.)

Waste places. 3-11.

Everywhere. This and the grass, Poa Annua, are considered to be the most common plants in the world.

\section{LEPIDIUM. (Pepper Wort.)}

I. L. campestre. Br. (Common Mithridate Pepper Wort.)

Dry gravelly soil. $5-8$.

Common. Headstone Drive, Corn-fields at Ruislip, etc.

2. L. ruderale. L. (Rubbish Pepperwort.)

Waste places, usually by the sea.

In some abundance by the canal at Alperton (Newbould). 
[L. sativum. L. (Common Garden Cress) often occurs on waste heaps and refuse from gardens, but has no claim to be indigenous.] Roxeth, Alperton. (Herb. Harr.) Harrow Weald. (Flor. Midd.)

\section{SENEBIERA. (Wart Cress.)}

I. S. coronopus. Poir. (Common Wart Cress, or Swine's Cress.)

Waste ground. Flowers all summer.

Road sides at Harrow, abundant along the Station Road, and Northwick Walk; also at Roxeth, and Pinner. This unpretending plant, the Coronopus Ruellii of Smith, is called by some "Star of the Earth."

\section{CAMELINA. (Gold of Pleasure.)}

I. C. sativa.* Cr. (Common Gold of Pleasure.)

Cultivated fields. 6,7 .

Corn-fields at Pinner; one plant found.

BRASSICA. (Cabbage or Turnip.)

I. B. Rapa.* L. (Common Turnip.)

Waste places and borders of fields. 5-7.

This plant is questionably indigenous. Like the following, it occurs commonly at Harrow.

2. B. Napus. L. (Rape or Cole-seed.)

Waste places. 5,6 .

Corn-fields at Wood End. Pretty frequently distributed at Harrow.

\section{SINAPIS. (Mustard.)}

I. S. nigra. L. (Black Mustard.)

Banks of streams and waste places. 6-8.

Between. Whitchurch and Stanmore. (Flor. Midd.) 
2. S. arvensis. L. (Wild Mustard, Charlock.)

Corn-fields and waste ground. 5-8.

Everywhere abundant.

3. S. alba. L. (White Mustard.)

Waste places. 6,7 .

Occasionally found on waste heaps, such as that by the Canal, Greenford, but not very frequent. Harrow, Harrow Weald, Stanmore, between Whitchurch and Stanmore. (Flor. Midd.)

\section{RAPHANUS. (Radish.)}

I. R. Raphanistrum. L. (Wild Radish, Jointed Charlock.)

Corn-fields and waste ground.

Side of Railway, between Harrow Station and iron bridge (var. with tawny petals). (Edition i.) Harrow, Roxeth, Pinner.

Commonly found white, as well as the usual colour, yellow.

Order VII. RESEDACE E. (Mrgnonette Tribe.)

\section{RESEDA. (Dyer's Rocket.)}

I. R. luteola. L. (Common Dyer's Rocket.)

Waste places. 6-8.

Growing as a weed in the Parsonage garden at Pinner. Opposite gate of Kingsbury Churchyard ; Stanmore Heath, a single plant. (Flor. Midd.)

Order Vili. Cistaceze. (Rock Rose Tribe.) HELIANTHEMUM. (Rock Rose.)

I. H. vulgare. Gaert. (Common Rock Rose.) Dry chalky banks and hilly places. 7-9. 
Pinner Hill. The only known site in Middlesex. A large patch discovered August 10, 1871, by W. A. Tooke, Esq.

\section{Order IX. Violaceef. (Vtolet Tribe.)}

\section{VIOLA. (Voilet.)}

I. V. odorata.* L. (Sweet Violet.)

Banks and woods. 3,4 .

Border of a field at Roxeth; lanes in Pinner, Harrow Park, the Poplars, Pinner, with white flowers.

2. V. sylvatica. Fries. (Wood Violet.)

Hedge banks and thickets. 4-6.

Common throughout the district. The prevailing form is that of the sub-species $V$. Riviniana, Reich. "The form V. flavicornis-Forst., not Smith-is found on Stanmore Heath." (Flor. Midd.)

3. V. canina. L. (Dog Violet.)

Sandy and peaty places. 4-6.

Sub-species $V$. flavicornis, Sm. Ruislip Common. Entered with a degree of doubt; but as the plants possess the characteristic yellow spur of the species, could not be omitted.

4. V. tricolor. L. (Pansy. Heartsease.)

Cultivated fields, etc. 5-8.

Common as a weed in cottage gardens, corn-fields at Pinner Hill.

B. V. arvensis. Murr. (Corn Pansy.)

Corn-fields. Flowers all summer.

Corn-fields at Ruislip; near Eastcott, and in gardens at Harrow and Pinner. Harrow Weald Common. (Flor. Midd.) 
Order X. Droseracefe. (Sundew Tribe.)

DROSERA. (Sundew.)

I. D. rotundifolia. 'L. (Round-leaved Sundew.)

Bogs and moist heathy ground. 7, 8 .

This curious little plant is to be found in the moist marshy parts of Harrow Weald Common.

[D. intermedia. Hayne. (Intermediate Sundew) is mentioned in Flor. Midd. as having been reported in 1793 from "Bogs on Ruislip and Harrow Heaths in great abundance"-but on questionable authority. The construction of the Ruislip Reservoir may likely have destroyed the plant in one of its habitats, and the excavating for gravel on Harrow Weald Common may have destroyed it in the other.]

ORder XI. POLYGalaCEAE. (MILKWORT TRIBE.)

\section{POLYGALA. (Milkwort.)}

I. P. vulgaris. L. (Common Milkwort.)

Dry hilly pastures. $5-8$.

Frequent; bank near Oxhey Wood, with pink flowers, Ruislip and Harrow Weald Commons, varying with dark and light blue, purple, and white blossoms. .

Not the typical form, but $P$. depressa, Wend. (Syme.)

Order Xiv. Caryophyllace E. (Clove Pink Tribe.)

\section{SILENE. (Catchfy.)}

I. S. inflata. Sm. (Bladder Campion.)

Pastures and road sides. 6-8. 
Common; ou the railway embankment, at Roxeth, Headstone Drive, Oxhey Farm. " Road south of Harrow Weald Common." (Flor. Midd.)

\section{LYCHNIS. (Campion.)}

I. L. Flos-Cuculi. L. (Meadow Lychnis. Ragged Robin.)

Moist meadows and pastures. 5,6 .

Commonly distributed.

2. L. diurna. Sibth. (Red Campion.)

Hedge banks, and in woods. 6,7 .

Very common; at Stanmore, in the Bentley Priory Woods, I found the white variety of this plant (not $L$. vespertina or white Campion), mentioned by Hooker and Arnott (edition viii. p. 62). "Petals red, very rarely nearly white." (Edition i.)

3. L. vespertina. Sibth. (White Campion.)

Fields. 6-9.

Ruislip. (Farrar.)

[A single plant of the Saponaria Vaccaria, L., which has no claim to be considered an English plant, much less to be indigenous here, was found at the Lime pits, Pinner.]

\section{AGROSTEMMA. (Corn Cockle.)}

\section{A. Githago. L. (Corn Cockle.)}

Corn-fields. 6-8.

Corn-fields at Ruislip; at Wood End. Probably an introduced plant, though now thoroughly naturalized in England. 


\section{SAGINA. (Pearlwort.)}

I. S. procumbens. L. (Procumbent Pearlwort.)

Waste places, walls, etc. 5-9.

Common on old walls, and as a weed in garden paths, etc.

2. S. apetala. L. (Annual small-flowered Pearlwort.) Walls, dry gravelly places.

On the Grove Wall, Harrow, near Harrow Station, old walls at Eastcott, etc. Not uncommon.

3. S. ciliata. Fr. (Ciliated Pearlwort.)

Dry places and sandy heaths. 5, 6 .

Lane near Ruislip School. "South side of Harrow Weald Common." (Flor. Midd.)

\section{ARENARIA. (Sandwort.)}

I. A. serpyllifolia. L. (Thyme-leaved Sandwort.) Dry places. 6-8.

Fields and gardens at Harrow and Pinner.

2. A. leptoclados. Guss.

Walls and dry places. 6-8.

The Grove Wall, Harrow. Headstone, Pinner.

3. A. trinervis. L. (Three-nerved Sandwort.)

Shady woods and moist places. 5, 6 .

Sides of hedge on the Station Road, Harrow, in Harrow Park, hedges in the Greenford Road, Churchyard fields, lane at Harrow Weald, etc.

\section{STELLARIA. (Stitchwort.)}

I. S. media With. (Common Chickweed.)

Waste places and road sides. Flowers all the year round.

Very common. 
2. S. Holostea. L. (Greater Stitchwort. Satin Flower.) Woods and hedges. 4-6.

Common everywhere.

3. S. glauca. Wither. (Marsh Stitchwort.)

Marshy places. 5-7.

Beside the Brent, near Stonebridge. "Ditch near plantation by the North Western Railway Bridge over Brent. H. J. Wharton." (Farrar.)

4. S. graminea. L. (Lesser Stitchwort.)

Dry pastures, fields, etc. $5-8$.

Frequent, at Alperton. Harrow Weald Common, Ruislip; Pinner, etc.; also near the stile in the Football Field, and in the new Churchyard.

5. S. uliginosa. Murr. (Bog Stitchwort.)

Ditches and rivulets. 5,6 .

Ditches at Ruislip, near Harrow Weald Common, ditches by Sheepcote Farm, Harrow, and many other places.

\section{CERASTIUM. (Mouse Ear Chickweed.)}

I. C. vulgatum. (Broad-leaved Mouse Ear Chickweed.) Fields, pastures, and road sides. 4-9.

Abundant in a waste field at Alperton, Grove wall, Harrow, old farm house wall at Sudbury. Pinner. ( $C$. glomeratum, Thuil.) Not nearly so common here as the next.

2. C. viscosum. L. (Narrow-leaved Mouse Ear Chickweed.)

Waste places, etc. 3-8.

Very common. (C. triviale, Link.)

c 2 
3. C. semidecandrum. L. (Little Chickweed.) Wall tops, dry waste places. 3-5.

I found a specimen of what I think is this, on the top of an old farm house wall, near Sudbury. (Edition i.)

4. C. arvense. L. (Field Chickweed.)

Dry, sandy, or gravelly places. 4-8.

Rare. Growing on the side of the railroad, between Harrow Station and the Kenton Bridge, and even there sparingly. It has probably been conveyed there in ballast. (Edition i.)

5. C. aquaticum. L. (Water Mouse Ear Chickweed.) Wet ditches.

Harrow Weald, Stanmore. Edgware. (Varcune). Neesdon, Roxborough Park. (Farrar.) This is by some botanists called Malachium aquaticum.

\section{Order XV. LINACEA. (FlaX TrIBe.)}

\section{LINUM. (Flax.)}

I. L. usitatissimum. (Common Blue Flax.)

Corn-fields and waste places.

Sparingly found at Harrow, on waste heaps, and by the road side at Greenford, and Pinner Drive. This is the flax of commerce.

2. L. catharticum. L. (Purging Flax.)

Pastures. 6-9.

Railway Embankment, bank on the way to Oxhey Wood, etc. Common. 
Order XVI. MaLVACEA. (Maliow Tribe.)

\section{MALVA. (Mallow.)}

I. M. sylvestris. L. (Common Mallow.)

Waste places and way sides. 6-9.

Frequently dispersed in waste places at Harrow, Greenford, Pinner, Stanmore, etc.

2. M. rotundifolia. L. (Dwarf Round-leaved Mallow.) Waste places, etc. 6-10.

Abundant in the "Foss," by the Grove, Harrow, waste heaps at Roxeth, Headstone Farm, Peterborough Road, Pinner.

3. M. moschata. L. (Musk Mallow.)

Pastures, hedges. 7, 8.

Road side at Pinner Hill. Woodhall, Ruislip, Stanmore, etc.

\section{Order XVII. TILIACEA. (LtMre Tribe.)}

\section{TILIA. (Lime.)}

I. T. Europæa.* L. (Common Lime Tree.)

Woods, plantations, etc. 7,8 .

The Churchyard, Harrow. Frequent throughout the district in plantations. Not native.

Order XVIII. HYPERICACE E. (ST. JoHN's Wort Tribe.)

HYPERICUM. (St. John's Wort.)

I. H. calycinum.* L. (Large Flowered St. John's Wort.)

Bushy places. 7-9. 
Julians, Harrow. On a hedge bank, but most likely planted there.

2. H. Androsæmum. L. (Tutsan.)

Woods and thickets. 7,8 .

Pinner Hill. Discovered by W. A. Tooke, Esq., October 1, 1874. Stanmore. (Flor Midd.)

3. H. perforatum. L. (Common Perforated St. John's Wort.)

Woods, hedges, and thickets. 7-9.

Commonly distributed.

4. H. quadrangulum. L. (Square-stalked St. John's Wort.)

Moist pastures, sides of ditches. 7,8 .

Frequent by the sides of ditches at Harrow, and by the Canal, Woodridings ponds, streams at Pinner. Stanmore Heath. (Flor. Midd.)

5. H. humifusum. L. (Trailing St. John's Wort.) Heathy, boggy, and gravelly places. 7,8 . Harrow Weald Common, abundant; Ruislip Common; Pinner Wood.

6. H. pulchrum. L. (Small upright St. John's Wort.) Dry woods and heaths. 6,7 .

Woods at Ruislip; Harrow Weald Common. Hedges at Pinner.

7. H. hirsutum. L. (Hairy St. John's Wort.)

Woods and thickets. 7,8 .

Hedge of a field at Greenhill, near the Roxborough Turnpike. Station Road, in the hedge. Frequent at Pinner and Harrow Weald. "Edgware, abundant." (Flor. Midd.) 
Order XIX. ACERACEA. (Maple Tribe.)

ACER. (Maple.)

1. A. Pseudo-Platanus.* L. (Greater Maple, or Sycamore.)

Hedges and plantations, not indigenous. 5, 6 . Frequent in hedgerows, etc., at Harrow.

2. A. campestre. L. (Maple.)

Woods and hedges. 5,6 .

Common in the hedgerows

Order XX. Geraniace E. (Crane's BuL Tribe.) •

\section{GERANIUM. (Crane's Bill.)}

I. G. phæum.* L. (Dusky Crane's Bill.)

Woods and thickets. 5-7.

In a field at Julian Hill. Doubtfully indigenous.

[G. striatum, L. (Pencilled Crane's Bill) has been long established on a hedge bank in Pinner Hill grounds.]

2. G. pratense. L. (Blue Meadow Crane's Bill.) Meadows and copses. 6-8.

In a meadow at Pinner Hill. Kingsbury Churchyard.

(Farrar.)

3. G. Pyrenaicum. L.

Meadows and pastures. 6.

Plentiful at Eastcott.

4. G. lucidum. L. (Shining Crane's Bill.)

Rocks, walls, etc. 5-8. 
Rare. On a sunken wall on the Greenford Road, about one hundred yards from the Church ; and also on a hedge bank in same road.

5. G. Robertianum. L. (Herb Robert, or Stinking Crane's Bill.)

Woods, sides of hedges, etc. 5-9.

Very common. The variety with white flowers occurs in the Grove, Harrow, but is gradually becoming rare. (Ed. i.)

6. G. molle. L. (Dove's-foot Crane's Bill.)

Waste places. 4-8.

Road side by Harrow Church, at Alperton, etc., not nearly so frequent as $G$. dissectum. In 1862 I found the variety with white flowers at Oxhey Wood. (Edition i.)

7. G. pusillum. L. (Small-flowered Crane's Bill.) Waste ground. 6-9.

"Harrow Weald Common." (Flor. Midd.) Rare.

8. G. rotundifolium.* L. (Round-leaved Crane's Bill.) Pastures and waste ground. 6, 7 .

Rare. Introduced in a garden at Roxeth.

9. G. dissectum. L. (Jagged-leaved Crane's Bill.) Hedges and pastures. 6, 7 .

Everywhere common.

\section{ERODIUM. (Stork's Bill.)}

I. E. cicutarium. Sm. (Hemlock Stork's Bill.)

Waste ground. 6-9.

Pinner Hill. (Tooke.) 
Order XXI. BaLSAMiNaCE A. (Balsam Tribe.)

\section{IMPATIENS. (Touch-me-not.)}

I. I. Noli-me-tangere.* L. (Common or Yellow Touch-me-not.)

A garden escape. 7-9.

In several places near Pinner Marsh.

Order XXII. OXALIDACE $\mathbb{E}$. (WoOd Sorrel Tribe.)

\section{OXALIS. (Wood Sorrel.)}

I. O. Acetosella. L. (Common Wood Sorrel.)

Woods and shady places. 5,6 .

Not very common. Pinner Wood; by a hedge on Harrow Weald Common.

SUB.CIASS II. CALYCIFLORE.

ORDER XXIII. STAPHYLEACEZE.

[Staphylea pinnata. L. (Common Bladder-nut.) Of some standing as a cultivated shrub in Harrow Vicarage garden.]

ORDER XXIV. CELASTRACEA.

EUONYMUS. (Spindle Tree.)

I. E. Europæus. L. (Common Spindle Tree.)

Woods and hedges. 5,6 . 
Hedges at Alperton, and at Greenford; Pinner Hill. Abundant in the Grove, Harrow, where there is a fine tree of it. (Edition i.)

Order XXV. Rhamnace

\section{RHAMNUS. (Buckthorn.)}

I. R. catharticus. L. (Common Buckthorn.)

Hedges and thickets. 5-7.

By the Brent near Neesdon. (Farrar.) Near Woodcock Farm. (S. J. Gunn.) "By the Brent, about Perivale." (Lees.)

2. R. Frangula. L. (Alder Buckthorn.)

Woods and thickets. 5, 6 .

Harrow Park, and Pinner. Harrow Weald. (Flor. Midd.) By the Brent, near Kingsbury. (Farrar.)

Order XXVi. Leguminose. (Pea and Bean Tribe.)

\section{ULEX. (Furze.)}

I. U. europæus. L. (Common Furze. Whin, or Gorse.) Heathy places. 2-7.

Harrow Weald Common, Ruislip Common, Stanmore, hedge at the top of Northwick Walk, etc.

Not uncommon.

2. U. nanus. Forst. (Dwarf Furze.) Heathy places. 8-11.

In a lane near Pinner Hill. (Mrs. Tooke.) 


\section{GENISTA. (Green Weed.)}

I. G. tinctoria. L. (Dyer's Green Weed, or Wood Waxen.)

Pastures, thickets. etc. 7-9.

Harrow Weald Common, Pinner Hill. I have observed it near Northolt: (Edition i.)

2. G. anglica. L. (Needle Green Weed, or Petty Whin.)

Heaths and mossy ground. 5,6 .

Harrow Weald and Ruislip Commons. Stanmore Heath. (Flor. Midd.)

\section{SAROTHAMNUS. (Broom.)}

I. S. scoparius. Wimm. (Common Broom.) Dry hills and bushy places. 5,6 .

Harrow Weald Common. Road side at Pinner Hill.

\section{ONONIS. (Rest Harrow.)}

I. O. arvensis. L. (Common Rest Harrow.)

Barren pastures. 6-9.

Harrow Weald and Ruislip Commons. (Edition i.)

2. O. campestris. Koch.

Barren places. 6-9.

Road side near Pinner Hill. Near Wembley Green.

(Farrar.) Near the Common and Church, Harrow Weald. (Flor. Midd.)

\section{MEDICAGO. (Medick.)}

I. M. lupulina. L. (Black Medick, or Nonsuch.) Waste and cultivated ground. 6, 7 . 
Abundant; very similar to Trifolium minus.

2. M. sativa.* L. (Lucerne.)

Cultivated and waste ground. 6, 7 .

Examples of this have been found at Pinner, but only as escapes from cultivation.

3. M. denticulata. Willd. ('Toothed Medick.)

Waste ground. 5-9.

A single plant was found on a manure heap near the Down Fields, Pinner.

\section{MELILOTUS. (Melilot.)}

r. M. officinalis. Willd. (Common Melilot.)

Way sides, and bushy places. 6-8.

Northolt, Greenford (F. W. Longman); Railway Embankment near Harrow Station; Pinner Cemetery.

2. M. arvensis.* Willd. (Corn-field Melilot.)

Waste places. 6-8.

Harrow Weald Common. (Flor. Midd.)

\section{TRIFOLIUM. (Clover, Trefoil.)}

I. T. repens. L. (White or Dutch Clover.)

Meadows and pastures. 5-9.

Abundant; a variety with variegated leaves occurs in a field at Roxborough, by the footpath.

2. T. pratense. L. (Common Purple Clover.) Meadows and pastures. 5-9. Very common.

3. T. medium. L. (Zigzag Trefoil.)

Pastures. 6-9. 
Way side at Pinner Hill; Stanmore Heath. (Flor. Midd.)

4. T. fragiferum. L. (Strawberry Trefoil.)

Moist pastures. 7-9.

Foot of Harrow Hill, Roxeth. Near the Clay Pits, Harrow Weald; 'and Harrow Railway Station. (Flor. Midd.)

5. T. procumbens. L. (Hop Trefoil.)

Corn-fields. 6-8.

Corn-fields at Wood End; Pinner Chalk Pits ; Harrow Weald Churchyard. (Flor. Midd.)

6. T. minus. Sm. (Lesser Yellow Clover.)

Dry pastures and road sides. 6,7 .

Very common.

7. T. filiforme. L. (Slender Yellow Trefoil.)

Dry pastures, walls, etc. Flowers all the summer months.

Embankment of Ruislip Reservoir.

LOTUS. (Bird's-foot Trefoil.)

I. L. corniculatus. L. (Common Bird's-foot Trefoil.) Pastures. 5-9.

Very common.

2. L. major. Scop. (Greater Bird's-foot Trefoil.) Sides of ditehes, moist bushy places. 7,8 . Common in moist hedges, etc., at Harrow.

\section{ORNITHOPUS. (Bird's-foot.)}

I. O. perpusillus. L. Common Bird's-foot.) Sandy and dry gravelly soil. 5-7, 
Harrow Weald and Ruislip Commons. It used to occur in the Peterborough road, which for a year or two was an excellent hunting field for the botanist, since the seeds of many plants had been brought there in the gravel laid on the road. (Edition i.)

\section{ONOBRYCHIS. (Saintfoin.)}

I. O. sativa.* Lam. (Common Saintfoin.)

Calcareous ground. 6, 7 .

The Railway bank near Pinner. (Farrar.)

\section{VICIA. (Vetch.)}

I. V. Cracca. L. (Tufted Vetch.)

Meadows, hedges. 6-8.

Pinner, in hedges; Railway Embankment, by Kenton Bridge; and generally throughout the district.

2. V. lathyroides. L. (Spring Vetch.)

Road sides and pastures. 4-6.

Waste ground at Ruislip.

3. V. sativa. L. (Common Vetch.)

Cultivated and waste ground. 5,6 .

Common. Railway Embankment, etc. The narrowleaved variety, $V$. angustifolia, is found at Alperton, at Greenhill and Harrow Weald.

4. V. sepium. L. (Bush Vetch.)

Woods and shady places. 6-8.

Banks at Horsington; at Pinner. Hedges at Pinner; Railway Embankment.

5. V. hirsuta. Koch. (Hairy Tare.)

Corn-fields and hedges. 6-8,

Very Common. Railway Embankment, etc. 
6. V. tetrasperma. Moench. (Slender Tare.)

Hedges, gravelly places. 6-8.

Pinner Drive and Railway Embankment. Roxeth; Pinner. Horsington Hill. (Flor. Midd.)

\section{LATHYRUS. (Vetchling, Everlasting Pea.)}

I. L. Nissolia. L. (Crimson Vetchling, or Grass Vetch.)

Bushy places. 5,6 .

Rare. Sparingly at Kenton Brook, and plentiful in a hedgerow near Kenton. (F. W. Longman.) Alperton and Sudbury.

2. L. pratensis. L. (Meadow Vetchling.)

Moist meadows and pastures. 7, 8 .

Very common throughout the district.

3. L. macrorrhizus. Wimm. (Tuberous Bitter Vetch.) Thickets and pastures.

Ruislip, near the Reservoir; Harrow, Railway Embankment. The variety $L$. tenuifolius found in woods at Pinner. This plant is the Orobus tuberosus of Linnæus.

Order XXVII. ROSACEA. (Rose Tribe.)

PRUNUS. (Plum and Cherry.)

I. P. communis. Huds. (Common Plum, Sloe, or Blackthorn.)

Hedges and woods. 4, 5 .

a. P. spinosa. L. (Sloe, or Blackthorn.)

Branches well armed with spines.

D 2 
Pinner Wood; frequent in hedges and copses throughout the district.

$\beta$. P. insititia. L. (Bullace.)

Armed with few spines.

In hedges at Harrow and Roxeth. Near Pinner Wood. (Flor. Midd.)

$\gamma$. P. domestica. L. (Wild Plum.)

Branches unarmed, or rarely with an occasional spine. In a lane near Northolt Road, Roxeth. Hedge north of Woodhall Farm, Pinner.

2. P. Avium. L. (Wild Cherry.)

Woods and hedges. 5 .

Harrow Park, and the Grove, Harrow. (Edition i.)

Porridge-pot Hill, Pinner. Bentley Priory. (Flor. Midd.)

3. P. Cerasus. L. (Dwarf Cherry.)

Copses and hedges. 5.

Near Harrow Weald Common. (Flor. Midd.) Entered here with a doubt as to the locality being in Middlesex.

4. P. Padus. L. (Bird Cherry.)

Woods and coppices. 5.

Harrow Park, Payne's Lane, Pinner, most likely introduced.

SPIRAA. (Meadow Sweet.)

I. S. Ulmaria. L. (Meadow Sweet.)

Meadows, banks of ponds and ditches. 6-8.

Frequent at Harrow and in the surrounding district. 


\section{GEUM. (Avens.)}

I. G. urbanum. L. (Common Avens.)

Woods and Hedges. 6-8.

Very Common.

\section{RUBUS. (Bramble and Raspberry.}

[A most difficult Genus, presenting innumerable varieties.]

I. R. Idæus. L. (Common Raspberry.)

Woods and Hedges. 6, 7 .

Harrow Park; hedge in the London Road by Mrs. Holt's house. Harrow Weald Common, and east side of the road skirting the Common. Stanmore Heath.

2. R. fruticosus. L. (Common Bramble, or Blackberry.) Thickets and hedges. 7, 8 .

[Of this variable plant the following Sub-species occur.]

I. R. affinis. W. and N. Horsington Wood. (Lees.)

2. R. Lindleianus. Lees. R. nitidus. Salt. Harrow Weald Common; Horsington Hill. (Lees.)

3. R. rhamnifolius. W. and N. Harrow Weald Common. (Flor. Midd.) Horsington Hill. (Lees.)

4. R. discolor. W. and N. Frequent throughout the district.

5. R. thyrsoideus. Wimm. Hedges at Roxeth.

6. R. leucostachys. Sm. Hedges at Harrow, and Harrow Weald Common. 
$\beta$. R. vestitus. Weihe. Shady places in Harrow Park. Horsington Wood. (Lees.)

7. villicaulis. W. and N. Pinner Wood.

8. R. macrophyllus. Weihe. Horsington Hill. (Flor. Midd.)

9. R. hystrix. Weihe. Shady places in Harrow Park.

I0. R. rosaceus. Weihe. Borders of drive to Pinner Hill.

II. R. pygmæus. Weihe. A rare form. On hedge bank, east side of Pinner Wood.

12. R. scaber. Weihe. Hedges at Harrow. Horsington Hill. (Lees.)

13. R. rudis. Weihe. Horsington Hill. (Lees.)

14. R. Radula. Weihe. Shady places at Wood End; Northolt.

I5. R. Koehleri. Weihe. Horsington Wood. (Lees.)

16. R. pallidus. Weihe. Harrow Weald Common. (Flor. Midd.)

I7. R. Lejeunii. Weihe. Rare. Edge of Oxhey Wood. Horsington Wood. (Lees.)

18. R. glandulosus. Bell. Horsington Hill. (Lees.)

19. R. Balfourianus. Blox. Hedges at Wood End, Northolt. Lane from Pinner Marsh to Field End.

20. R. corylifolius. Sm. Hedges at Harrow.

a. R. sublustris. Lees. Hedges at Pinner. 
$\beta$. R. conjungens. Bab. Hedge in Uxbridge Road, Roxeth.

$\gamma$. R. purpureus. Bab.? Hedges at Harrow.

2r. R. althæifolius. Host. Hedge of Football Field, Harrow. Lanes near Pinner.

22. R. tuberculatus. Bab. R. dumetorum. Blox. Harrow. Horsington Hill. (Flor. Midd.)

23. R. cæsius. L. Perivale. (Lees.) [The Pinner Station belongs to $R$. althaifolius.]

\section{FRAGARIA. (Strawberry.)}

I. F. vesca. L. (Wood Strawberry.)

Woods and thickets. 5-7.

Frequent in the Grove, Harrow Park, Pinner Wood, and throughout the district.

2. F. elatior.* Ehrh. (Hautboy Strawberry.)

Hedges, etc. Probably everywhere escaped from cultivation. 6-9.

Railway embankment near Kenton, 1863; most likely an escape from some garden. Pinner Cemetery, accidentally introduced, now likely extinct.

\section{POTENTILLA. (Cinque-foil.)}

I. P. anserina. L. (Silver Weed, Goose Grass, Wild Tansy.)

Road sides, moist meadows. $6,7$.

Very common by the road sides. 
2. P. reptans. L. (Common Creeping Cinque-foil.)

Meadows, way sides. 6-9.

Very common everywhere.

3. P. Tormentilla. Sibth. (Tormentil Sept-foil.)

Moors and heathy places. 6-8.

Harrow Weald and Ruislip Commons. I have found the flowers double at the former place. It very often occurs with five petals, though four is the usual number. It is the Tormentilla officinalis of Smith. (Edition i.)

$\beta$. P. procumbens. Sibth. T. reptans. L. Horsington Hill. (Flor. Midd.)

4. P. fragariastrum. Ehrh. (Strawberry-leaved Potentilla, Barren Strawberry.)

Woods, banks, and pastures. 3-6.

Very common, and similar to the Fragaria vesca; it is the Fragaria sterilis of Linnæus.

\section{ALCHEMILLA. (Lady's Mantle.)}

I. A. vulgaris. L. (Common Lady's Mantle.) Hill pastures. 6-8.

Harrow. (Flor. Midd.) Stanmore. (Varenne.)

2. A. arvensis. L. (Field Lady's Mantle or Parsley Piert.)

Fields, gravelly soils. 5-8.

Ruislip Common and Harrow Weald; waste ground at Pinner.

\section{SANGUISORBA. (Burnet.)}

I. S. officinalis. L. (Great Burnet.)

Moist meadows. 6-8. 
Whitchurch and Stanmore. (Varenne.) Near Stonebridge. (Wharton.) Kingsbury. (Flor. Midd.)

\section{POTERIUM. (Salad Burnet.)}

I. P. Sanguisorba. L.* (Salad Burnet.)

Dry calcareous soil. 6-8.

Pinner Hill. A single plant accidentally introduced.

\section{AGRIMONIA, (Agrimony.)}

\section{A. Eupatoria. L. (Common Agrimony.)}

Borders of fields and meadows. 6, 7 .

Common at Harrow and throughout the district.

ROSA. (Rose, Sweet Briar.)

I. R. rubiginosa. L. (True Sweet Briar.)

Bushy Places. 6, 7.

Hedge near Football Field; in the Greenford Road, near the Green Lane; and at Roxeth. Porridge-pot Hill, Pinner. Stanmore; (Varenne.)

2. R. villosa. L. (Villous Rose.)

Hedges, etc. 6, 7.

A north country plant, apparently indigenous in a field near the Railway Station at Greenhill, also in the hedge at Roxeth, by the Harrow Gasworks.

3. R. tomentosa. Sm. (Downy-leaved Rose.)

Hedges. 6, 7.

At Roxeth. I have found it in a hedge at Greenhill. (Edition i.)

4. R. Canina. L. (Common Dog Rose.)

Hedges, etc. Abundant. 6, 7 . 
The following varieties are found here.

R. sarmentacea. Woods.

R. surculosa. Woods.

R. Forsteri. Sm.

Hardly differing from $\mathbf{R}$.

canina.

5. R. systyla. Woods. (Close Styled Dog Rose.) Hedges. 6, 7 .

"Near Pinner Railway Station." (Flor. Midd.)

6. R. arvensis. L. (Trailing White Dog Rose.)

Woods, Hedges, etc. 6, 7 .

Common in most of the hedges.

\section{MESPILUS. (Medlar.)}

I. M. germanica.* L. (Common Medlar.)

Hedges and woods, scarcely wild. 5, 6 .

The Grove, Harrow.

CRAT ÆGUS. (Hawthorn, May, Whitethorn.)

I. C. oxyacantha. L. (Hawthorn.)

Woods and hedges. 5, 6 .

Abundant. At Alperton I found a dark pink variety in a hedge near the Canal Bridge. (Edition i.)

a. C. oxyacantha. L. Jacq. Having one to three styles and nuts, fruit oval.

Harrow, Nower Hill, Pinner. Ruislip, Alperton, Horsington Hill. (Flor. Midd.)

B. C. monogyna. Jacq. Having only one style and one nut, fruit subglobose.

The more usual form. 'Found in all hedges. 


\section{PYRUS. (Pear, Apple, Service Tree.)}

I. P. communis.* L. (Wild Pear.)

Woods and hedges. 4, 5. (See Flor Midd.)

The Grove and Harrow Park? Between Neesdon and Blackpot Hill. (Farrar.)

2. P. Malus. L. (Crab Apple.)

Woods and hedges. 5 .

Not unfrequent in the hedges at Harrow; at Pinner, Harrow Weald and throughout the district.

3. P. torminalis. Sm. (Wild Service Tree.)

Woods and hedges. 4-6.

Hedge in Football Field. Pinner Wood. Rare.

4. P. Aucuparia.* Gærtn. (Mountain Ash, or Rowan Tree.)

Woods and plantations. 5, 6 .

The Grove, Harrow Park, and several other plantations.

5. P. Aria. Sm. (White Beam Tree.)

Woods. 5,6 .

A fine tree in the Grove, Harrow, probably planted there. (Edition i.) Hedges near Alperton. (Newbould.)

Order XXVIII. ONAGRaCeAe. (Whlow Herb Tribe.)

\section{EPILOBIUM. (Willow Herb).}

I. E. angustifolium.* L. (Rose-bay, or French Willow Herb.)

Moist woods and banks. 7,8.

Harrow Weald; Pinner. 
2. E. hirsutum. L. (Great Hairy Willow Herb, Codlings and Cream.)

Sides of ditches, canals, etc. 7,8 .

Common by the side of streams and the Canal. The Brook, Pinner.

3. E. parviflorum. Schreb. (Small-flowered Hairy Willow Herb.)

Marshes and ditches. 7, 8 .

Canal, also in many ditches at Harrow, Ruislip, Pinner, etc.

4. E. montanum. L. (Broad smooth-leaved Willow Herb.)

Dry shady banks, etc. 6,7 .

Common in Harrow Park, the Grove, and throughout the district.

5. E. roseum. Schreb. (Pale Smooth-leaved Willow Herb.)

Moist places. 7,8 .

Moss Lane, Pinner, near the brook.

6. E. tetragonum. L. (Square-stalked Willow Herb.) Sides of ditches and watery places. 7,8 . Ditches, etc., at Harrow. Very common.

7. E. obscurum. Schreb. (Twiggy Willow Herb.) Wet places. 7,8 .

Harrow; Moss Lane, Pinner. Harrow Weald Common and Stanmore Heath. (Flor. Midd.)

\section{CIRCAEA. (Enchanter's Nightshade.)}

I. C. lutetiana. L. (Common Enchanter's Nightshade.) Woods and shady places. 6-8.

Harrow Park; the Grove, Harrow. (Edition i.) Not uncommon in Pinner. 
Order XXIX. HALORAGACE E. (Mare's Tatl Tribe.)

\section{MYRIOPHYLLUM. (Water Milfoil.)}

I. M. verticillatum. L. (Whorled Water Milfoil.)

Ponds and ditches. 7,8.

Ditch near Greenford. (Farrar.)

2. M. spicatum. L. (Spiked Water Milfoil.)

Ditches and stagnant ponds. $6,7$.

Canal, Greenford; pond near Ruislip Common; pond in Bentley Priory grounds. (Flor. Midd.)

Order XXX. LYthrace . (Purple Loosestrife Tribe.)

\section{LYTHRUM. (Purple Loosestrife.)}

I. L. Salicaria. L. (Spiked Purple Loosestrife.)

Watery and marshy places. 7-9.

Canal, near Greenford and Alperton; in abundance at the river Brent. Ruislip; Woodridings, Pinner.

\section{PEPLIS. (Water Purslane.)}

I. P. Portula. L. (Common water Purslane.)

Watery places. 6-8.

Harrow Weald and Ruislip Commons. Field End, Eastcott; Stanmore Heath. (Flor. Midd.)

Order XXXII. CUCURBITACE E. (Gourd Tribe.)

\section{BRYONIA. (Bryony.)}

I. B. dioica. Jacq. (Red-berried Bryony.)

Thickets and hedges. 5-9.

Not unfrequent in the hedges at Harrow, Roxeth, Pinner, etc. 
Order XXXIII. PortulacaceÆ. (Purslane Tribe.)

\section{MONTIA. (Water Blinks.)}

I. M. fontana. L. (Blinks, or Water Chickweed).

Wet and marshy ground. 4-8.

Ruislip and Harrow Weald Commons; frequent.

Stanmore Heath; (Flor. Midd.)

[Claytonia perfoliata, Don. as a weed, introduced with foreign soil, at The Grove, Stanmore.]

Order XXXIV. Paronychiace瓜. (Straptort Tribe.)

\section{[POLYCARPUN. (All-seed.)}

I. P. tetraphyllum.* L. (Four-leaved All-seed.)

Garden at Harrow, occuring by accident, 6, 7.

It is a native of the south-west coast and Channel Islands, and has no business whatever in the Flora of Harrow.]

\section{SPERGULARIA. (Sandwort Spurrey.)}

I. S. rubra. A. St. Hil. (Field Sandwort Spurrey.) Lepigonum rubrum. Fr.

Gravelly or sandy soils. 6-9.

New Churchyard Path, Peterborough Road, Harrow, and Harrow Weald Common, in abundance. Pinner Cemetery; Pinner Hill. This genus is the Arenaria of Linnæus, and by some transferred, together with Polycarpon and Spergula, to the Nat. Ord. Caryophyllacea.

\section{SPERGULA. (Spurrey.)}

I. S. arvensis. L. (Corn Spurrey.) Corn-fields and waste ground, 6-8. 
a. S. arvensis. R. Seeds with minute raised points. Alperton. (Flor. Midd.)

$\beta$. S. vulgaris. Bœningh. Seeds with white or brown club-shaped papillæ.

Corn-fields, Ruislip; Woodridings, Pinner. Stanmore Heath, Harrow Weald Common. (Flor. Midd.)

Order XXXV. CrassulaceÆ. (House Leek Tribe.)

\section{TILLAA.}

I. T. muscosa. L. (Mossy Tillæa.)

Barren sandy heaths. 6,7 .

On an old wall near Kingsbury. (Wharton.)

\section{SEMPERVIVUM. (House Leek.)}

I. S. tectorum.* L. (Common House Leek.)

House tops and on walls. 7, 8 .

Not unfrequent on the roofs of cottages. A questionably indigenous plant.

\section{SEDUM. (Stonecrop.)}

I. S. Telephium. L. (Orpine. Livelong.) Hedgebanlss and thickets. 7, 8.

Stanmore. (Varenne.) Copse in Headstone Lane, Pinner; plentiful. Not unlikely the S. Fabaria, Koch.

2. S. album.* L. (White Stonecrop.)

Calcareous rocks and walls. 7,8.

Stanmore, probably not wild. (Varenne.) Introduced from Westmoreland into several Gardens in Pinner. 
3. S. acre. L. (Biting Stonecrop.)

Walls, etc. 6,7 .

Grove wall, Harrow; garden wall at Roxeth. Stanmore. (Flor. Midd.)

4. S. reflexum. L. (Crooked Yellow Stonecrop.)

Walls, roofs of houses, etc. 7,8 .

Old garden wall at Roxeth, growing with $S$. acre. Stanmore. (Flor. Midd.)

Order XXXVI. Grossulariace侏. (Gooseberry Tribe.)

RIBES. (Currant, Gooseberry.)

I. R. rubrum.* L. (Red Currant.)

Woods and hedges. 4, 5.

Harrow Park.

2. R. Grossularia.* L. (Common Gooseberry.)

Hedges and thickets. 4, 5 .

Grove wall, Harrow; and Harrow Park: both these plants are doubtfully indigenous here.

Order XXXVII. SaXifragace牲. (Saxifrage Ttire.)

I. S. tridactylites. L. (Rue-leaved Saxifrage.)

Old walls. 4-7.

Grove wall, Harrow ; wall of Hogarth cottage, Crown Street; kitchen garden wall of Harrow Park, the wall was however partially removed about 1865 or 1866 , so it may be now extinct in this locality; walls at Headstone, Pinner and Eastcott. Stanmore. (Flor. Midd.) 
ORder XXXVIII. UMBELLIFERE. (UMBELITFEROUS OR Hemlock Tribe.)

HYDROCOTYLE.

(White-rot.)

I. H. vulgaris. L. (Common White-rot, or Marsh Pennywort.)

Bogs and marshes. 5-8.

Frequent at Harrow Weald and Ruislip Commons; also in the wet ground round Ruislip Reservoir. Stanmore Heath. (Flor. Midd.)

\section{SANICULA. (Sanicle.)}

I. S. europea. L. (Wood Sanicle.)

Woods and thickets. 6,7 .

Woods at Bentley Priory, Stanmore, Pinner Wood.

\section{APIUM. (Celery.)}

I. A. graveolens.* L. (Smallage, or Wild Celery.)

Wet places, generally near the sea. 6-8.

Railway Bank, near Railway Bridge. (Farrar.) Greenford, and between Perivale and Harrow. (Lees.) All likely garden escapes.

\section{PETROSELINUM. (Parsley.)}

I. P. sativum.* Hoffm. (Common Parsley.)

Old walls. 6-8.

On an old garden wall in the rear of houses in Crown Street, Hog Lane, Harrow, now nearly extinct there.

\section{HELOSCIADIUM. (Marsh Wort.)}

I. H. nodiflorum. Koch. (Procumbent Marsh Wort.) Sides of rivulets and ditches. 7, 8 .

Side of Canal, Greenford; streams at Pinner. 
2. H. inundatum. Koch. (Least Marsh Wort.) Pools and lakes. 6, 7 .

Pools on Harrow Weald Common, the plants entirely or nearly submerged; also in a pond at Alperton. Pinner Hill. Stanmore Heath. (Flor. Midd.)

\section{SISON. (Bastard Stone Parsley.)}

\section{S. Amomum. L. (Hedge Stone Parsley.)}

Banks and moist ground. 8,9 .

Very frequent by the road side. The whole plant has a disagreeable odour. Especially common at Roxborough, near the turnpike on the Pinner Road.

\section{AGOPODIUM. (Gout Weed.)}

I. A Podagraria. L. (Common Gout Weed, or Bishop's Weed.)

Gardens and shady places. 6-8.

Harrow Park, abundant; small garden enclosure at Pinner, and Mr. Smith's garden, near the Cricket Field, Harrow. A plant formerly introduced into gardens by the monks.

\section{[CARUM.}

I. C. Carui. L. (Caraway.)

Meadows and pastures. 6.

Railway Bank, Pinner. (Farrar.)]

\section{BUNIUM. (Earth Nut, Pig Nut.)}

'r. B. flexuosum. With. (Common Earth Nut.)

Woods and pastures. 5,6 .

Pinner Road, Harrow Park, Pinner and Stanmore Woods. Frequent. The root is often eaten. 


\section{PIMPINELLA. (Burnet Saxifrage.)}

I. P. Saxifraga. L. (Common Burnet Saxifrage.)

Dry pastures. 7-9.

Very common in the fields and by road sides.

2. P. magna. L. (Great Burnet Saxifrage.)

Shady places. 7,8 .

"In a meadow on the left hand on this side Brent Bridge, near Kingsbury, in Harrow-on-the-Hill Road. Mr. Vardy." (Doody MSS. in Flor. Midd.)

\section{SIUM. (Water Parsnep.)}

I. S. angustifolium. L. (Narrow-leaved Water Parsnep.)

Ditches and rivulets. 7, 8 .

Canal at Greenford; Harrow Weald; Eastcott. Alperton. (Lees.) The Brent. (Farrar.)

\section{[BUPLEURUM. (Hare's Ear.)}

I. B. rotundifolium.* L. (Thorough-Wax.)

Corn-fields on a chalky soil. 7 .

A single plant unaccountably appeared in the Parsonage garden, Pinner, in 1869. ]

\section{CENANTHE. (Water Dropwort.}

I. EE. fistulosa. L. (Common Water Dropwort.)

Ditches. 7-9.

Wet pastures at Ruislip.

2. CE. silaifolia. Bieb.? (Silaus-leaved Water Dropwort.)

Marshes. 6. 
Banks of the Brent, near Greenford; side of the Brent, near Preston. Opposite Woodford House, Kingsbury. (Farrar.)

3. CE. Phellandrium. Lam. (Fine-leaved Water Dropwort. Horsebane.)

Ditches and ponds. 7-9.

"In the Brent at Alperton, abundant." (Lees.)

\section{ATHUSA. (Fool's Parsley.)}

I. A. Cynapium. L. (Common Fool's Parsley.)

Fields, gardens, and waste ground. 7-9.

Abundant as a weed in gardens and on waste heaps. Whole plant very poisonous.

\section{SILAUS. (Pepper Saxifrage.)}

I. S. pratensis. Besser. (Meadow Pepper Saxifrage.) Pastures and meadows. 6-9.

Headstone Drive, not unfrequent in the meadows at Harrow, especially in the field at the back of the Grove. Of constant occurrence at Pinner. Both this and the Sison Amomum are abundant here, though rare in the North.

\section{ANGELICA. (Angelica.)}

I. A. sylvestris. L. (Wild Angelica.)

Moist woods and marshy places. 7,8.

Not unfrequent in Pinner Wood, and by ditches; etc. Common along the road by the bathing place.

\section{PASTINACA. (Parsnep.)}

I. P. sativa. L. (Common Wild Parsnep.)

Borders of fields and pastures. 7, 8.

Not unfrequent on the Railway Embankment: in a field at Roxeth. Chalk-pits, Pinner. 


\section{HERACLEUM. (Cow Parsnep.)}

I. H. Sphondylium. L. (Common Cow Parsnep, or Hog Weed.)

Hedges, pastures, and bushy places. 7-9

Everywhere abundant.

\section{CONIUM. (Hemlock.)}

I. C. maculatum. L. (True Hemlock.)

Waste places and banks 6,7 .

At Roxeth ; in a field adjoining the Roxborough Turnpike on the Pinner Road; hedges at Roxborough; waste ground at Horsington; fields near the Rifle Range; Headstone, Pinner.

\section{SMYRNIUM. (Alexanders.)}

I. S. Olusatrum.* L. (Common Alexanders.)

Waste ground and among ruins. 4-6.

Among the ruins of old Stanmore Church. (F. W. Longman.)

\section{SCANDIX. (Shepherd's Needle.)}

I. S. Pecten-Veneris. L. (Common Shepherd's Needle, or Venus' Comb.)

Corn-fields. 6-9.

At Wood End and Kenton; among the corn. Pinner and Ruislip.

\section{ANTHRISCUS. (Beaked Parsley.)}

I. A. sylvestris. Hoffm. (Wild Beaked Parsley.)

Hedges and borders of fields. 4-6.

Everywhere common. The first of this tribe to come. into flower. 


\section{CHAROPHYLLUM. (Chervil.)}

I. C. temulum. L. (Rough Chervil.)

Hedges and copses. 6, 7 .

Very common; somewhat similar to Anthriscus sylvestris, but comes into flower just when the other goes to seed.

\section{DAUCUS. (Carrot.)}

I. D. Carota. L. (Wild Carrot.)

Pastures and borders of fields. 6-8.

Hedges and Railway Embankment. Very frequent throughout the district.

\section{TORILIS. (Hedge Parsley.)}

r. T. Anthriscus. Gærtn. (Upright Hedge Parsley.) Hedges and waste places. 7-9.

Very common. This plant comes into flower when Charophyllum goes out.

Order XXXIX. araliace无. (Aralia Tribe.)

\section{ADOXA. (Moschatel.)}

r. A. Moschatellina. L. (Tuberous Moschatel.) Woods and shady banks. 4, 5 .

Fields by Blackpot Farm, near the Brent. (Farrar.)

\section{HEDERA. (Ivy.)}

1. H. Helix. L. (Common Iry.)

Woods, old buildings, etc. 10,11 .

Abundant in all hedgerows, woods and copses. 
Order Xl. CORNACEA. (Cornel Tribe.)

\section{CORNUS. (Cornel.)}

r. C. sanguinea. L. (Wild Cornel, or Dogwood.) Woods and thickets. 6,7 .

Hedges at Harrow, Pinner Wood, etc. Very frequent.

Order Xli. LORANTHACE

\section{VISCUM. (Mistletoe.)}

1. V. album. L. (Common Mistletoe.)

Parasitical on trees. 3,4 .

On an apple tree at the Manor House, Pinner (recently destroyed). On apple trees and thorns at Northwood; formerly abundant. "On lime trees at Cannons, Whitchurch." (Pet. Collinson.)

Order XlII. CAPRIFOlLACEA. (Honeysuckle Tribe.)

\section{SAMBUCUS. (Elder.)}

I. S. Ebulus. L. (Dwarf Elder. Dane Wort.) Hedge banks. 8 .

Near Greenford. (Lees.)

2. S. nigra. L. (Common Elder.)

Woods, coppices, etc. 6,7 .

Common in plantations, such as the Grove and Harrow Park; also not unfrequent in the hedges. 


\section{VIBURNUM. (Guelder Rose.)}

I. V. Lantana. L. (Mealy Guelder Rose, or Wayfaring Tree.)

Woods and hedges. 5, 6 .

In Harrow Park. (Edition i.)

2. V. Opulus. L. (Common Guelder Rose.)

Woods and coppices. 6, 7 .

Abundant in Harrow Park, near the Archery ground; in hedges at Wood End; Pinner Wood.

\section{LONICERA. (Honeysuckle.)}

I. L. Periclymenum. L. (Common Honeysuckle, or Woodbine.)

Woods and hedges. 6-9.

Frequent. Along the Kenton Road hedge, between the Turnpike and the Harrow side of the Railway Bridge is found the variety Quercifolia, the leaves being lobed like that of an oak. The same variety is found in the Green Lane, by the Greenford Road. (Edition i.)

2. L. Xylosteum.* L. (Upright Fly Honeysuckle.) Thickets and woods. 5,6 .

Two shrubs of this plant are found in the Grove, Harrow, which have both been undoubtedly planted at some remote period. (Edition i.)

Order Xliti. RUBIACEAE. (Madder Tribe.)

GALIUM. (Bedstraw.)

I. G. verum. L. (Yellow Bedstraw.)

Dry banks. 6-9. 
Field near Harrow Station, Railway Embankment, bank at Wood End. Not unfrequent in hedges at Kenton, near Kenton Brook, Harrow Weald and Pinner.

2. G. saxatile. L. (Smooth Heath Bedstraw.)

Heathy spots." 6-8.

Very common at Harrow Weald and Ruislip. Stanmore Heath. (Flor. Midd.)

3. G. uliginosum. L. (Rough Marsh Bedstraw.)

Wet meadows and sides of ditches. 7,8 .

Ponds at Roxeth. Exceedingly similar to the next. It does not turn black in drying, which $G$. palustre does.

4. G. palustre. L. (White Water Bedstraw.)

Sides of ditches, rivulets, etc. 7,8 .

Very common everywhere.

a. G. elongatum. Syme. Roxeth.

$\beta$. G. genuinum. Syme. Harrow.

$\gamma$. Witheringii. Syme. Harrow Weald Common. (Flor. Midd.)

5. G. Mollugo. L. Great (White Hedge Bedstraw.) Hedges and thickets. 7,8,

Hedges at Harrow, etc. Woodhall, Pinner; Harrow Weald. (Flor. Midd.) Greenford. (Cooper.) Very common.

6. G. Aparine. L. (Goose Grass, or Cleavers.) Hedges. 6, 7 .

Most abundant. This plant is known in some places by the name of "Scratch tongue." 


\section{SHERARDIA. (Field Madder.)}

I. S. arvensis. L. (Blue Sherardia, or Little Field Madder.)

Corn-fields and gravelly soil. 4-10.

Fields at Ruislip; Pinner Hill ; near Harrow Railway Station. (Farrar.) Horsington Hill. (Flor. Midd.)

\section{ASPERULA. (Woodruff:)}

I. A. odorata. L. (Sweet Woodruff.)

Woods and shady places. 5,6 .

Ruislip; path by Julian Hill, Harrow. (Farrar.)

Stanmore. (Flor. Midd.)

Order Xliv. Valerianace

CENTRANTHUS. (Spur Valerian.)

I. C. ruber.* DC. (Red Spur Valerian.)

Chalky ground and old walls. 6-9.

Headstone Moat; likely from cultivation.

\section{VALERIANA. (Valerian.)}

I. V. officinalis. L. (Great Wild Valerian.)

Ditches and sides of rivers. 6-8.

Ditches at Ruislip, side of Pinner Brook.

2. V. dioica. L. (Small Marsh Valerian.)

Moist places. 5, 6 .

Wet pastures at Ruislip. 


\section{FEDIA. (Corn Salad.)}

I. F. olitoria. Vahl. (Common Corn Salad, or Lamb's Lettuce.)

Banks and corn fields. 4-6.

Not very frequent. Banks at Roxeth. In Dr. Dove's garden, Pinner, at the foot of and on the walls.

2. F. dentata. Deitr. (Smooth Narrow-fruited Corn Salad.)

Corn-fields and hedge banks. 6-8.

Found in corn-fields at Ruislip.

\section{Ordek XlV. DIPSACE E. (Teazel Tribe.)}

\section{DIPSACUS. (Teazel.)}

r. D. sylvestris. L. (Wild Teazel.)

Road sides and hedges. 8, 9 .

Very common by the road sides at Harrow; Nower Hill, Pinner; Alperton; Edgware. (Flor. Midd.)

\section{SCABIOSA. (Scabious.)}

I. S. succisa. L. (Premorse, or Devil's Bit Scabious.) Meadows and pastures. 7-10.

Railway Embankment; and abundant in the fields about Harrow, Pinner, and Ruislip. Stonebridge. (Farrar.)

\section{KNAUTIA. (Knautia.)}

I. K. arvensis. Coult. (Field Scabious, or Knautia.) Pastures and corn-fields. 6-8. 
Pastures at Greenford. Abundant on the Railway Embankment. Chalk pits, Pinner. Stanmore. (Varenne.)

Order XlVi. COMPOSIT e. (Compound Flowers.)

This is the largest Natural order of Plants. It has been subdivided into three tribes:

1. The CiChoraceÆ. (Chicory and Dandelion Tribe.)

2. The Cynarocephale. (ARtichoke, or Thistle Tribe.)

3. The CORYMbiferee. (Hemp Agrmony and Colt's-Foot TRIBE.)

Tribe L. CichoraceÆ. (Chicony Tribe.)

\section{TRAGOPOGON. (Goat's Beard.)}

I. T. pratensis. L. (Yellow Goat's Beard.)

B. T. minor. Fries.

Meadows and pastures. 6,7 .

Foot-ball-field; Railway Embankment; side of Canal, Greenford, etc.; not unfrequent. Meadows at Wood End and Pinner. A familiar name of this plant is, "Jack go to bed at noon," in allusion to its petals being closed at noonday.

2. T. porrifolius.* L. (Purple Goat's Beard, or Salsafy.) Moist meadows and pastures. 5, 6 .

"Several spots in the neighbourhood of Greenhill and Roxeth." Not indigenous.

HELMINTHIA. (Ox Tongue.)

I. H. echioides. Gærtn. (Bristly Ox Tongue.) Borders of fields and way sides. 
Pinner Road, common; Greenhill and Kenton; Road side, Pinner. Horsington Hill; between Sudbury Station and Alperton. (Flor. Midd.)

\section{APARGIA. (Hawkbit.)}

I. A. hispida. Willd. (Rough Hawkbit.)

Meadows and pastures. 6-9.

Not unfrequent at Alperton and Pinner. Stanmore. (Varenne.) Horsington Hill. (Flor. Midd.)

2. A. autumnalis. Willd. (Autumnal Hawkbit.)

Meadows. 8, 9.

Not unfrequent in meadows at Harrow. Stanmore. (Varenne.)

\section{THRINCIA. (Thrincia.)}

I. T. hirta. D.C. (Hairy Thrincia.)

Gravelly pastures and moors. 6, 7 .

Pastures at Harrow, such as the Cricket Field, Pinner, etc.; very common. Mr. Bentham unites both Apargia and this to the genus Leontodon, or Dandelion.

\section{HYPOCH ERIS. (Cat's Ear.)}

I. H. radicata. L. (Long-rooted Cat's Ear.) Meadows and way sides. 7, 8 .

Very common everywhere.

\section{LACTUCA. (Lettuce.)}

I. L. virosa. L. (Strong-scented Lettuce.)

Banks and way sides, 7, 8.

Found in abundance along the Pinner and Greenford 
roads; in the lanes at Pinner and Eastcott. It is one of the rarities of Harrow. The whole plant is poisonous.

2. L. Scariola. L. (Prickly Lettuce.)

Waste ground, rare. 8,9 .

Near Harrow. (Hemsley.)

3. L. muralis. DC. (Ivy-leaved Lettuce.)

Banks, rocks, and old walls. 7, 8 .

Headstone Lane and Payne's Lane, Pinner; Pinner Hill ; Ruislip Church.

\section{SONCHUS. (Sow Thistle.)}

I. S. arvensis. L. (Corn Sow Thistle.)

Corn-fields. 8, 9.

Near Kenton, and in Headstone Drive; Pinner Hill. Alperton; Harrow Weald Churchyard. (Flor. Midd.)

2. S. oleraceus. L. (Common Annual Sow Thistle.) Waste places and cultivated ground. 6-8.

Abundant; both the varieties, with leaves divided and leaves entire, found commonly.

3. S. asper. Hoffm. (Sharp-fringed Annual Sow Thistle.) Waste places. 6-8.

At Kenton, and road sides, Harrow ; Pinner; not so common as the preceding. I also have found it at Greenford, near the Canal. (Edition i.)

\section{CREPIS. (Hawk's Beard.)}

I. C. virens. L. (Smooth Hawk's Beard.)

Dry pastures, etc. 6-9.

Ruislip, abundant; Headstone Drive; Roxborough;

Pinner. 


\section{LEONTODON. (Dandelion.)}

I. L. Taraxacum. L. (Common Dandelion.)

Meadows and pastures. 3-10.

Abundant everywhere, flowering almost all the year round. I have twice found a monstrosity with two heads on one flower stalk. (Edition i.)

ß. erythrospermum. DC. (Narrow Leaved Dandelion.)

Old walls, dry waste places and roadsides. 5-7. Common throughout the County. (Flor. Midd.)

\section{HIERACIUM. (Hawkweed.)}

I. H. Pilosella. L. (Common Mouse Ear Hawkweed.) Banks and dry pastures. 5-8.

Railway Fmbankment, Rickmansworth Road, Harrow Weald Common, etc. Not unfrequent.

2. H. aurantiacum.* L. (Orange Hawkweed.) Woods. An outcast from cottage gardens. 6, 7. Old wall at Miss Hill's, near Cricket ground; growing in parement at Mrs. Willett's, Pinner.

3. H. vulgatum. Fries. (Wood Hawkweed.)

Frequent in woods and on banks. 7-9.

Harrow Weald Common, Ruislip Wood. Stanmore Heath; Bentley Priory. (Flor. Midd.)

4. H. boreale. Fries. (Shrubby broad-leared Hawkweed.)

Woods, hedges. 7,8 .

Found at Harrow Weald Common. Horsington Wood, (Lees.) Stanmore Heath. (Flor. Midd.) 


\section{LAPSANA. (Nipple Wort.)}

I. L. communis. L. (Common Nipple Wort.) Waste and cultivated ground. 7-9. Very common everywhere.

Tribe II. Cynarocephalat. (Thistle Tribe.)

\section{ARCTIUM. (Burdock.)}

I. A. majus. Schk. (Great Burdock.)

Waste places and way sides. 7,8 .

Harrow; Wood End; Porridge-pot Hill, Pinner.

2. A. minus. Schk. (Lesser Burdock.)

Waste places. 8 .

Roxeth. Harrow Weald. (Flor. Midd.)

3. A. intermedium. Lange. (Intermediate Burdock.)

Waste places. 8.

Harrow. Alperton; Horsington Hill; Cannons; Whitchurch. (Flor. Midd.)

\section{SERRATULA. (Saw-wort.)}

I. S. tinctoria. L. (Common Saw-wort.)

Thickets and pastures. 8, 9.

Meadows at Roxeth, and a copse at Headstone, Pinner. Kingsbury. (Farrar.)

\section{CARDUUS. (Thistle.)}

I. C. Marianus.* L. (Milk Thistle.) Banks.

In gardens at Roxeth, not wild. Occurred spontaneously 
in Pinner in 1865 and subsequent years where an old fence had stood.

2. C. acanthoides. L. (Welted Thistle.)

Way sides and waste places. 6-8.

"Near Harrow Weald Common." (Flor. Midd.)

\section{CARLINA. (Carline Thistle.)}

I C. vulgaris. L. (Common Carline Thistle.)

Dry sandy heaths. 7-9.

Ruislip Common. The flowers, which expand in dry weather, and close before rain, retain this property after they are dried, and are used as hygrometers.

\section{CNICUS. (Plume Thistle.)}

I. C. lanceolatus. Willd. (Spear Plume Thistle.) Way sides and pastures. 7,8 .

Not unfrequent in the road sides at Harrow, etc.

2. C. palustris. Willd. (Marsh Plume Thistle.) Moist meadows. 7,8.

Abundant. The tallest English species, being on an average 4 feet 6 inches high, flowers sometimes white.

3. C. arvensis. Hoffm. (Creeping Field Plume Thistle.)

Fields and road sides. 7, 8,

Everywhere abundant.

4. C. pratensis. Willd. (Meadow Plume Thistle.)

Wet Pastures. 6-8.

Marshy pastures at Ruislip. Stanmore Heath. (Flor.

Herts. Supp.) 
5. C. acaulis. Willd. (Stemless Dwarf Plume Thistle.) Dry gravelly pastures. 7-9. Not unfrequent on Ruislip Common.

\section{CENTAUREA. (Knapweed.)}

I. C. nigra. L. (Common Black Discoid Knapweed.) Meadows and pastures. 6-10.

Abundant everywhere. In the field behind the Grove, Harrow, I once found a rayed variety, which perhaps is C. nigrescens, Godr. (Black-rayed Knapweed.) (Edition i.)

2. C. Cyanus. L. (Corn Blue Bottle.)

Corn-fields and waste ground. 6-8.

Near the Chalk Pits, Pinner.

\section{TRIBE III. CORYMBIFERA.}

\section{BIDENS. (Bur Marigold.}

I. B. cernua. L. (Nodding Bur Marigold.)

Sides of rivulets, ditches, etc. 7-10.

Pools at Harrow. Weald Stone. Stanmore Heath. (Flor. Midd.) Larger than the next in all its parts.

2. B. tripartita. L. (Trifid Bur Marigold.) Marshy places, sides of ponds. 7-9.

Pond in a field near the junction of the Perivale and Greenford Roads, Grove Pond, and by a pool at Greenhill. Kingsbury. (Farrar.)

\section{EUPATORIUM. (Hemp Agrimony.)}

\section{E. cannabinum.* (Common Hemp Agrimony.)}

Banks of streams and ditches. 8, 9 .

A single chance plant at Pinner. (Bank of the Colne

near Hamper Mill, beyond the limits of the Harrow district.) 


\section{TANACETUM. L. (Tansy.)}

I. T. vulgare. L. (Common Tansy.)

Borders of fields and road sides. 8, 9 .

Occasionally found in waste places at Harrow, and on the banks of the. Brent.

\section{ARTEMISIA. (Worm Wood.)}

I. A. vulgaris. L. (Common Wormwood, or Mugwort.) Sides of hedges. 7-9.

Banks at Greenhill; Woodridings, Pinner. Near Weald Park. (Farrar.)

\section{GNAPHALIUM. (Cudweed.)}

I. G. uliginosum. L. (Marsh Cudweed.)

Sandy and wet places. 7-9.

Cricket field, Harrow; by the road side at Pinner; and on the Rickmansworth Road; Ruislip, etc.

2. G. sylvaticum. L. (Highland Cudweed.)

Heaths and woods. 7-9.

Harrow Weald Common; Stanmore Heath. (Flor. Midd.)

\section{FILAGO. (Filago.)}

I. F. minima. Pers. (Least Filago, or Cudweed.)

Dry and gravelly places. 6-9.

Harrow Weald Common. Stanmore Heath. (Varenne.)

2. F. germanica. L. (Common Filago.)

Sandy and gravelly places, and dry pastures. 7-9.

Banks at Eastcott. Stanmore. (Varenne.) Harrow Weald Common. (Flor. Midd.) 


\section{PETASITES. (Butterbur.)}

I. P. vulgaris. Desf.

Swamps. 3,4 .

Near the Lake, Bentley Priory.

[P. fragrans.* Presl. An alien : is well established near the gate from Julians, into Harrow Park.]

\section{TUSSILAGO. (Colt's-Foot.)}

I. T. Farfara. L. (Common Colt's-Foot.)

Moist and clay soils. 3,4 .

Abundant; by the road sides and on the Railway Embankment.

SOLIDAGO. (Golden Rod.)

I. S. Virgaurea. L. (Common Yellow Golden Rod.) Woods and thickets. 7-9.

Pinner Wood.

\section{SENECIO. (Groundsel, Ragwort, Fleawort.)}

I. S. vulgaris. L. (Common Groundsel.)

Waste places. 1-12.

Abundant.

2. S. sylvaticus. L. (Mountain Groundsel.)

Dry soils, banks, and gravelly pastures. 7-9.

Edges of corn-fields at Ruislip; on Harrow Weald

Common. Stanmore Heath. (Flor. Midd.)

3. S. erucæfolius. L. (Hoary Ragwort.)

Way sides and pastures. 7-9.

Railway Embankment, fields, etc. ; very abundant. 
4. S. aquaticus. Huds. (Marsh Ragwort.)

Wet places. 7,8 .

Frequent throughout the district, and with $S$. erucifolius, taking the place of the more common $S$. Jacobaa, L. which has not been found here.

\section{INULA. (Elecampane.)}

I. I. Conyza. DC. (Ploughman's Spikenard.) Calcareous soil. 7-9.

Between Perivale and Horsington Hill. Lees.

\section{PULICARIA. (Flea Bane.)}

I. P. dysenterica. Gærtn. (Common Yellow Flea Bane.) Moist places; sides of hedges, etc. 7-9. Generally dispersed throughout these parts.

\section{BELLIS. (Daisy.)}

I. B. perennis. L. (Common Daisy.)

Pastures and road sides. 2-10.

Abundant.

\section{CHRYSANTHEMUM. (Oxeye Daisy.)}

I. C. Leucanthemum. L. (Great White Oxeye Daisy.) Dry pastures. 6-8.

Railway Embankment, fields, etc.; abundant.

2. C. segetum.* L. (Corn Marigold.)

Corn-fields. 6-8. "A single plant on Harrow Weald Common." (Flor. Midd.) 
MATRICARIA. (Wild Chamomile Feverfew.)

I. M. Parthenium. L. (Common Feverfew.)

Waste places, and in hedges. 6-9.

Field at the back of the King's Head Hotel, Harrow; Julian Hill; road side at Harrow Weald; Moss Lane, Pinner. This and the following are the Pyrethrum of Smith.

2. M. inodora. L. (Corn Feverfew, or Scentless Mayweed.)

Fields and way sides. 6-10.

Very common in waste places.

3. M. Chamomilla. L. (Common, Wild Chamomile.) Corn-fields and waste ground. 6-8. Harrow Weald; waste ground at Harrow.

\section{ANTHEMIS. (Chamomile.)}

I. A. Cotula. L. (Stinking Chamomile.) Waste places; by way sides. 6-9.

Not uncommon throughout the district.

ACHILLAA. (Yarrow, Milfoil.)

I. A. Ptarmica. L. (Sneezewort Yarrow). Moist meadows and pastures. 7, 8 .

Headstone Drive; fields at Pinner; field behind the Grove, Harrow. Stanmore Heath. (Flor. Midd.)

\section{A. Millefolium. L. (Common Milfoil.)}

Pastures and way sides. 6-9.

Very common. Flowers sometimes found rose-coloured. 
Order XlViI. Campanulace e. (Bell Flower Tribe.)

\section{CAMPANULA.}

I. C. rotundifolia. L. (Round-leaved Bell Flower, or Common Blue Harebell.)

Dry and hilly pastures. 7-9. Ruislip and Harrow Weald Commons.

2. C. Trachelium. L. (Nettle-leaved Bell-flower.) Woods and hedge-banks. 7,8. Borders of Horsington Wood. Lees.

3. C. hybrida.* L. (Corn Bell-flower.) Chalky corn-fields. 6-9.

A single plant at Pinner in 1870 .

[Phyteuma orbiculare. L. (Round-headed Rampion.) Recorded by the authors of "Indigenous Botany," 1793. Lane betwixt Kingsbury and Harrow, and meadows between Harrow and Pinner. Likely an error. (See Flor. Midd.)

\section{JASIONE. (Sheep's Scabious.)}

I. J. montana. L. (Annual Sheep's bit, or Sheep's Scabious.)

Dry banks and hills. 7 .

Stanmore, 1815. (See Flor. Midd.)

Sub-Class III. COROLLIFLORE.

Order L. ericaceE. (Heath Tribe.) ERICA. (Heath.)

I. E. Tetralix. L. (Cross-leaved Heath.) Heaths and moory ground. 7, 8. Harrow Weald Common; Stanmore Heath.

G 2 


\section{CALLUNA. (Ling.)}

I. C. vulgaris. Salisb. (Common Heather, or Ling.) Heaths and moory ground and woods. 6-8.

Harrow Weald Common, Ruislip Common, Stanmore Heath. Peterborough Road, Harrow. (Edition i.)

ORDER LI. PYROLACEAE.

\section{PYROLA. (Winter-green.)}

r. P. minor. L. (Lesser Winter-green.)

Mossy woods and thickets. 6, 7 .

Covering a large space on the turf at the Grove, Stanmore. This interesting addition to the Flora of Middlesex was made in June, 1874.

Order LIII. aQUIFOliace

\section{ILEX. (Holly.)}

I. I. Aquifolium. L. (Common Holly.)

Hedges and woods. 5-8.

Not unfrequent in plantations or hedges. Pinner Wood.

Order liv. Oleaceer. (Olive Tribe.)

LIGUSTRUM. (Privet.)

I. L. vulgare. L. (Privet, or Primprint.)

Thickets and hedges. 6,7 .

Very common in the hedges, where it is often planted. 


\section{FRAXINUS. (Ash.)}

I. F. excelsior. L. (Common Ash.)

Woods and hedges. 4, 5 .

Not unfrequent.

Order lV. apocynace ee. (Dog's Bane, or Periwinkle Tribe.)

\section{VINCA. (Periwinkle.)}

I. V. minor. L. (Lesser Periwinkle). Hedges and banks in woods. 4-6.

Abundant in the Grove, Harrow, and Bentley Priory Woods, near Stanmore. The white-flowered variety has been planted outside Harrow Chapel.

2. V. major.* (Greater Periwinkle.)

Woods and thickets. 4, 5 .

Hedge in Horsington Lane, suspiciously near some cottages, and Station Road, Harrow. This plant is probably not indigenous.

\section{Order LVI. Gentianace e. (Gentian Tribt.)}

\section{CHLORA. (Yellow-wort.)}

I. C. perfoliata. L. (Perfoliate Yellow-wort.)

Dry, chalky, or sandy ground. 7-9.

Road sides near Pinner Hill. (R. Ord.) Several plants in flower were gathered in 1863 ; it has not been observed since.

\section{ERYTHRAA. (Centaury.)}

I. E. Centaurium. Pers. (Common Centaury.)

Dry pastures. 6-9. 
Railway Embankment, Harrow; Ruislip Wood, and by the Reservoir, Ruislip; way sides and pastures at Pinner. A form with white flowers occurs plentifully on the bank of Ruislip Reservoir.

Order lVit. POlemoniace e. (Jacob's ladder Tribe.)

\section{POLEMONIUM. (Jacob's Ladder.)}

I. P. cœruleum.* L. (Blue Jacob's Ladder.)

Bushy hilly places, rare. 7 .

In a plantation at Pinner Hill. No doubt a garden escape.

Order lViti. CONVOlvulaceet. (Convolvulus Tribe.)

\section{CONVOLVULUS. (Bindweed.)}

I. C. arvensis. L. (Small Bindweed.)

Corn-fields, hedges, etc. $6,7$.

Headstone Drive; Station Road, Harrow; Railway Embankment; corn-fields at Ruislip and Pinner.

CALYSTEGIA. (Hooded Bindweed.)

I. C. sepium. Br. (Great White Bindweed.) Hedges. 6-8.

Commonly distributed.

Order liX. Boraginace E. (Borage Tribe.)

\section{PULMONARIA. (Lungwort.)}

I. P. officinalis.* L. (Common Lungwort.)

Woods and thickets. 5,6 . 
I found one or two plants in the Grove, Harrow; probably not indigenous there. (Edition i.)

\section{LITHOSPERMUM. (Gromwell.)}

I. L. arvense.* L. (Corn Gromwell.)

Cornfields. 5-7.

Roxborough Park, Harrow. Introduced with soil. (Farrar.)

\section{MYOSOTIS. (Scorpion Grass.)}

I. M. palustris. With. (Creeping Water Scorpion Grass, or Forget-me-not.)

Ditches and sides of rivers. 6-8.

Canal, Greenford, in abundance; River Brent.

2. M. repens. Don. (Creeping Water Scorpion Grass.) Moist boggy places. 6-8.

Ditches near Headstone Drive; marshy ground by Ruislip Reservoir.

3. M. cæspitosa. Schultz. (Tufted Water Scorpion Grass.)

Watery places. 6-8.

Not unfrequent in moist situations at Greenford, etc. Stanmore Heath. (Flor. Midd.)

4. M. arvensis. Hoffm. (Field Forget-me-not.) Hedge banks, etc. $5-8$. Abundant.

5. M. collina. Hoffm. (Early Field Scorpion Grass.) Wall tops and sandy banks. 4, 5 .

Greenford Churchyard wall, and very scarce there.

(Edition i.) Ruislip. (Flor. Midd.) 
6. M. versicolor. Ehrh. (Yellow and Blue-flowered Scorpion Grass.)

Wet and dry meadows and pastures. 4-6.

Side of pool at Northolt; at Alperton, in waste ground, abundant; and near the Brent. (Edition i.)

\section{ANCHUSA. (Alkanet.)}

I. A. sempervirens.* L. (Evergreen Alkanet.)

Waste ground; not indigenous. 5,6 .

Occurs occasionally as a weed in gardens at Harrow, but cannot have a claim to be indigenous here. (Edition i.)

\section{BORAGO. (Borage.)}

I. B. officinalis.* L. (Common Borage.)

Among rubbish and waste ground. 6,7 .

Waste heaps and gardens; scarcely indigenous anywhere. The Lodge, Pinner. West Street, Harrow.

Order lX. SOlanaceet. (Nightshade, or Potato Tribe.)

\section{SOLANUM. Nightshade.}

I. S. Dulcamara. L. (Woody Nightshade, or Bitter Sweet.)

Moist hedges and thickets. 6-8.

Very common in all the hedges.

2. S. nigrum. L. (Common White-flowered Nightshade.)

Waste Places. 6-11.

Occurs on waste heaps, and refuse from gardens; not very common. A weed in gardens at Pinner. 


\section{DATURA. (Thorn Apple.)}

\section{[I. D. Stramonium.* L. (Common Thorn Apple.)}

\section{Waste ground. 6, 7 .}

On rubbish and in gardens at The Lodge and Torrington House, Pinner.]

\section{HYOSCYAMUS. (Henbane.)}

I. H. niger.* L. (Black Henbane.)

Waste ground. 5-7.

In a cottage garden at Pinner Common. The narcotic properties of the plant are well known.

Order lXi. OrobanchaCEA. (Broom-rape Tribe.)

\section{OROBANCHE. (Broom-rape.)}

I. O. Hederæ.* Duby. (Ivy Broom-rape.) Parasitical, usually on Iry. 6, 7.

A single Plant appeared in June and July 1868 at Pinner, parasitical on a scarlet Pelargonium. Another plant appeared with several stems on the same plant in 1869.

Order LXII. SCROphulariace

\section{VERONICA. (Speedwell.)}

I. V. serpyllifolia. L. (Thymeleaved Speedwell). Pastures and road sides. 5, 6.

Very common.

2. V. scutellata. L. (Marsh Speedwell.)

Wet places, sides of ditches. 
Ditches and moist places on Harrow Weald Common; also abundant by the side of Ruislip Reservoir. Stanmore Heath. Flor. Midd.)

3. V. Anagallis. L. (Water Speedwell.)

Slow streams and muddy pools. 6-8.

The brook, Ruislip; Pond at Pinner Hill. The Brent, near Kingsbury. (Farrar.)

4. V. Beccabunga. L. (Brook-lime.)

Ditches, sides of rivers. 5-9.

Abundant in most of the ditches and ponds, such as Harrow Pond, Canal, etc.

5. V. officinalis. L. (Common Light Blue Speedwell.) Woods and pastures. 5-7.

Harrow Weald Common; Pinner; Ruislip Wood; Horsington Hill. (Flor. Midd.)

6. V. montana. L. (Mountain Speedwell.)

Moist woods. 4-7.

Harrow Park and the Grove; in the former place most abundant.

7. V. Chamædrys. L. (Germander Speedwell.) Woods and pastures, and hedge banks. 5, 6 . Abundant.

8. V. hederifolia. L. (Ivy-leaved Speedwell.)

Fields and hedge banks. 3-8.

Cultivated fields at Greenford; in gardens at Pinner; in corn-fields at Ruislip. Plentiful in the hedge bank at the west side of the Old Church new Burying Ground.

9. V. agrestis. L. (Green procumbent Field Speedwell.) Fields and waste places. 4.9 .

Abundant. 
I0. V. polita. Fries. (Grey procumbent Field Speedwell.)

Cultivated and waste ground. 4-9.

Frequent in Harrow and Pinner. Northolt; (Edition i.) Stanmore; Horsington Hill; (Flor. Midd.)

II. V. Buxbaumii.* (Buxbaum's Speedwell.)

Fields and cultivated places. 4-9.

This plant until very recently unknown in England, is now, strange to say, pretty frequently dispersed. I have found it here in a corn-field at Ruislip; and as weeds in gardens at Roxeth. (Edition i.) Sparingly near Perivale, on the Canal Towing Path; West Street, Harrow. Stanmore; Horsington Hill. (Flor Midd.)

12. V. arvensis. L. (Wall Speedwell.)

Fields and walls. 4-7.

Abundantly distributed.

I3. V. peregrina.* L. (Foreign Speedwell.)

Pinner Hill.

The plant was unknown to the British Flora a few years ago; it is now making itself at home in all parts of the country. The Editor found it in 1860 and subsequent years in Belfast, Co. Antrim, in 1871 at Gweedore, Co. Donegal; and again in 1871 at Pinner Hill.

\section{BARTSIA. (Bartsia.)}

I. B. Odontites. Huds. (Red Bartsia.)

Corn-fields and waste places. 6-8.

Road sides at Woodridings, Pinner; also near Pinner Church; and not unfrequently dispersed at Harrow.

\section{EUPHRASIA. (Eye Bright.)}

I. E. officinalis. L. (Common Eye Bright.) Dry heathy pastures. 5-9. 
Ruislip and Harrow Weald Commons; Pinner Hill; Stanmore Heath. (Flor. Midd.)

\section{RHINANTHUS. (Yellow Rattle.)}

I. R. Crista Galli. L. (Common Yellow Rattle.)

Meadows and pastures. 5-7.

Common. Football Field; field by Northwick Walk, Harrow; at Roxeth and Pinner.

\section{MELAMPYRUM. (Cow Wheat.)}

I. M. pratense. L. (Common Yellow Cow Wheat.) Groves and Thickets. 5-8.

Ruislip and Pinner woods. This and the last turn completely black on drying.

\section{SCROPHULARIA. (Figwort.)}

I. S. nodosa. L. (Knotted-rooted Figwort.)

Woods and moist grounds. 6-8.

Commonly distributed.

2. S. aquatica. L. (Water Figwort.)

Sides of rivers and in wet places. 6-9.

Ditches at Eastcott ; side of Ruislip Reservoir ; ditches at Pinner; the Brent. (Farrar.) Horsington Hill. (Flor. Midd.) Greenford. (Cooper.)

\section{PEDICULARIS. (Lousewort.)}

I. P. sylvatica. L. (Common Lousewort.)

Moist pastures and heaths. 4-7.

Ruislip and Harrow Weald Commons; in the latter place occasionally varying with very light pink or even white flowers. Stanmore Heath. (Flor. Midd.) 


\section{DIGITALIS. (Foxglove or Folksglove.)}

\section{D. purpurea. L. (Common Purple Foxglove.)}

Dry banks and woods. 5-8.

Pinner Hill; Harrow Weald Common; banks at Harrow Weald; at the second place I found a variety with the corolla not spotted within, as is usual. (Edition i.)

\section{ANTIRRHINUM. (Snapdragon.)}

I. A. majus.* (Great Snapdragon.)

Old walls. $7-9$,

Kitchen garden wall at the Grove, Harrow, in all its varieties of colour, from white, red and white, to the deepest red. Also on a wall near Stanmore Church. (F. W. Longman.)

\section{LINARIA. (Toadflax.)}

\section{L. Cymbalaria.* Mill. (Ivy-leaved Toadflax.)}

Old walls. 5-9.

Old walls at Eastcott in two places; Pinner; abundant on the Vicarage wall; at Stanmore; at Sudbury.

The outcast of gardens: called "Mother of Thousands" from its many flowers.

2. L. spuria. Mill. (Round-leaved Fluellen, or Toadflax.)

Sandy fields, waste ground. 5-9.

In the waste field by the Roxborough Turnpike, on the Pinner Road, abundant. It is not at all a common plant. In corn-fields at Pinner Hill and Greenford. At Stanmore. (Flor. Midd.) 
3. L. Elatine. Desf. (Sharp-pointed Fluellen, or Toadflax.)

Corn-fields and waste ground. 7-11.

Corn-fields at Pinner Hill.

4. L. vulgaris. Mill. (Yellow Toadflax.)

Borders of corn-fields, etc. 7-10.

Banks at Wembley. At Stanmore. (Flor. Midd.) Kingsbury Churchyard. (Farrar.)

[L. purpurea.* Mill. (Purple Toadflax.)

Old walls. 7,8 .

A naturalized alien. Well established on an old garden wall at Pinner, and appears spontaneously in the adjoining gardens.]

\section{VERBASCUM. (Mullein.)}

I. V. Thapsus. L. (Great Yellow hoary Mullein.)

Walls and waste ground. 6-8.

Drury's garden wall, by the racquet courts; and by the turnpike at Roxborough. Not uncommon in Pinner. Locally called Adam's Flannel-Ass's Ear.

2. V. Blattaria.* L. (Moth Mullein.)

Gravelly banks, rare. 8 .

Terrilands Pinner. London Hill, Roxeth.

3. V. virgatum.* With. ('Twiggy Mullein.)

Gravelly banks, rare. 8.

West end Pinner.

Order lXiII. labiate. (Labiate Tribe.)

\section{LYCOPUS. (Gipsywort.)}

I. L. europæus. L. (Common Gipsywort, or Water Horehound.) 
Ditches and river banks. 6-9.

Side of Canal at Greenford, River Brent, Harrow Park.

\section{MENTHA. (Mint.)}

I. M. viridis.* L. (Spearmint.)

Marshy places. 8,9 .

Canal bank at Alperton and the side of a stream at Harrow Weald.

2. M. piperita.* Sm. (Peppermint.) Watery places. 8,9 .

Side of Canal at Greenford. Probably not indigenous.

3. M. aquatica. L. (Common Water Capitate Mint.) Banks of rivers and marshes. 8, 9 .

Very common. Often called Mentha hirsuta, L.

4. M. arvensis. L. (Cornmint.)

Corn-fields, etc. 8,9 .

Road sides at Harrow and Pinner. Not uncommon.

5. M. sativa. L.

Sides of streams. 6-9.

Stanmore; (Varenne.) By the Brent, Alferton; (Lees.)

6. M. rubra. Sm. (Tall Red Mint.)

Wet places. 6-9.

On the footway from Harrow to Stanmore.

7. M. gracilis. Sm. Var. M. cardiaca, Baker.

Wet places. 6-9.

Roadside leading to Pinner.

8. M. Pulegium. L. (Penny Royal.)

Wet places, rare.

Edge of small pond at Pinner Hill.

H 2 


\section{THYMUS. (Thyme.)}

I. T. Chamædrys. Fries. (Wild Thyme.)

Hills and dry pastures. 6-8.

Ruislip and Harrow Weald Commons, bank at Eastcott.

\section{TEUCRIUM. (Germander.)}

r. T. Scorodonia. L. (Wood Sage, or Wild Germander.)

Woods and dry stony places. 7,8 .

Pinner Drive, Ruislip Wood, Harrow Weald Common, etc.

\section{AJUGA. (Bugle.)}

I. A. reptans. L. (Common Blue Bugle.)

Moist pastures and woods. 5,6 .

Common everywhere. A variety with white flowers once found in Harrow Park by the Rev. F. W. Farrar; and by the ruins of old Stanmore Church F. W. Longman found a pink variety. (1863.)

\section{BALLOTA. (Horehound.)}

I. B. nigra. L. (Black Horehound.)

Waste places. 6-10.

Road sides at Harrow. Abundant. It is sometimes called $B$. fretida, on account of its unpleasant odour.

\section{GALEOPSIS. (Hemp Nettle.)}

I. G. Tetrahit. L. (Common Red Hemp Nettle.) Corn-fields. 7-9.

Corn-fields at Roxeth. The form $G$. bifida, Bonn., occurs at Pinner and Ruislip Common. 
2. G. versicolor. Curt. (Large Flowered Hemp Nettle.)

Cultivated ground. 7, 8 .

Cornfields, near Ruislip Common: only two plants seen.

\section{GALEOBDOLON. (Weasel Snout.)}

I. G. luteum. Huds. (Yellow Archangel, or Weasel Snout.)

Woods and shady places. 4-6.

Hedges in Horsington Lane, near Greenford.

\section{LAMIUM. (Dead Nettle.)}

I. L. album. L. (White Dead Nettle.) Borders of fields and waste places. 5-9. Abundant.

2. L. maculatum.* L. (Spotted-leaved Dead Nettle.) By hedges. 6-9.

In a hedge at Kenton, by the road side. I only found two plants; the flowers are purplish white, the leaves spotted. Hooker and Arnott (Ed. viii. p. 332) make it a variety of $L$. album; so does Bentham. (Edition i.)

[A recent examination of the very fragmentary specimen in my herbarium, collected at Kenton in June 1863, tends to confirm me in the belief that it is a variety of $L$. album, and not the true L. maculatum, L. (J. C. M.)]

3. L. purpureum. L. (Red Dead Nettle.)

Borders of fields and in hedges. 4-10.

Abundant.

\section{BETONICA. (Betony.)}

I. B. officinalis. L. (Wood Betony.)

Woods and thickets. 6-8. 
Wood by Ruislip Reservoir; Harrow Weald Common; and Pinner Wood. Horsington Hill; Stanmore Heath. (Flor. Midd.)

\section{STACHYS. (Woundwort.)}

I. S. sylvatica. L. (Purple Hedge Woundwort.)

Woods and hedges. 7,8.

Everywhere common.

2. S. palustris. L. (Marsh Woundwort.)

River banks, moist places. 7, 8 .

Side of Canal at Greenford and Ruislip Reservoir.

3. S. arvensis. L. (Field Woundwort.)

Cornfields. 7-9.

Gardens at Pinner.

\section{NEPETA. (Cat-mint.)}

I. N. Cataria. L. (Cat-mint.)

Hedge banks and sandy ground, 7, 8 .

Between Perivale and Alperton. (Lees.)

\section{GLECHOMA. (Ground Ivy.)}

I. G. hederacea. L. (Common Ground Ivy.)

Hedges and waste places. 3-5.

Grove, Harrow; Harrow Park, etc.; and plentiful in most of the hedges.

\section{CALAMINTHA. (Calamint.)}

I. C. Clinopodium. Benth. (Common Wild Calamint, or Basil.)

Hills and dry bushy places. 7-9.

Harrow Weald Common, and hedge banks Pinner.

Stanmore. (Varenne.) 


\section{PRUNELLA. (Self-heal.)}

I. P. vulgaris. L. (Common Self-heal.)

Moist Pastures.' 7, 8.

Very common. Might be mistaken for a stunted specimen of Ajuga reptans, or Common Bugle.

\section{SCUTELLARIA. (Skull Cap.)}

x. S. galericulata. L. (Common Skull Cap.)

Banks of rivers and lakes. 7, 8 .

Side of Canal at Greenford and Alperton. Bank of Ruislip Reservoir.

2. S. minor. L. (Lesser Skull Cap.)

Moist heathy places. 7-10.

Not uncommon in the moist parts of Harrow Weald Common; also it grows amongst the loose stones of Headstone Drive, very sparingly, however. It is not at all a common plant.

\section{Order LXIV. VERBENACEÆ. (Vervain Tribe.)}

\section{VERBENA. (Vervain.)}

I. V. officinalis. L. (Common Vervain.)

Road sides and waste ground. 7-9.

Road side near the Church, Harrow; close by the Grove gates; Pinner Wood (F. W. Longman); and on the road as you enter Pinner. Very plentiful in Waxwell Lane, Pinner: at Headstone. Between Perivale and Alperton. (Lees.) 
Order lXVi. Primulace e. (Primrose Tribe.)

\section{HOTTONIA. (Water Violet.)}

I. H. palustris. (Common Water Violet, or Featherfoil.) Ditches and pools. 5-7.

In a pool in a plantation nearly opposite Woodford House, Kingsbury. (Farrar.)

\section{PRIMULA. (Primrose, Oxlip, Cowslip.)}

I. P. vulgaris. Huds. (Common Primrose.)

Woods, hedge banks, and pastures. 4, 5 .

The Grove, Harrow, abundant; banks at Roxeth; Headstone; Pinner Hill; Bentley Priory Woods. The form $P$. caulescens which is often mistaken for the following, is found at Wood End.

\section{Ia. P. variabilis. Gasp. (Jacquin's Oxlip.)}

Woods and meadows. 4, 5 .

I found one plant growing with the primroses at Stanmore, in the Bentley Priory Woods. (Edition i.) In pastures at Harrow and Pinner.

The true $P$. elatior, Jacq., does not occur in the district.

2. P. veris. L. (Common Cowslip or Paigle.)

Meadows and pastures. 4, 5.

Football field, and abundant on the Railway Embankment. Pinner Hill. Kingsbury. (Farrar.) Northolt. (Cole.) Bentley Priory.

\section{LYSIMACHIA. (Loosestrife.)}

I. L. vulgaris. L. (Great Yellow Loosestrife.) Sides of Pools and streams. 7.

Side of the Brent. (Farrar.) By the Brent, Perivale. (Lees.) 
2. L. nemorum. L. (Yellow Pimpernel, or Wood Loosestrife.)

Woods and shady places. $5-8$.

Pinner Wood; Stonebridge and Kingsbury. (Farrar.) Wembley Park. (Cole.) Stanmore. (See Flor. Midd.)

3. L. Nummúlaria. L. (Creeping Yellow Loosestrife, Moneywort, or Herb Twopence.)

Shady places and pastures. 6, 7 .

Headstone Drive; Football Field; fields at Roxeth: Pinner; Ruislip; Harrow Weald. Stanmore; Horsington Hill. (Flor. Midd.)

\section{ANAGALLIS. (Pimpernel.)}

I. A. arvensis. L. (Scarlet Pimpernel, Shepherd's Eye Glass, or Poor Man's Weather Glass.) .

Corn-fields and waste places. 5-11.

Clay pits near Harrow Weald, corn-fields at Ruislip; Pinner, etc. It is curious that the only three scarlet English flowers, namely this, the Red Poppy, and the Pheasant's Eye, have been introduced at some remote period with the corn. (Edition i.)

Order LXViII. Plantaginacea. (Plantain Tribe.)

\section{PLANTAGO. (Plantain.)}

I. P. major. L. (Greater Plantain.)

Pastures and road sides. 6-8.

Everywhere abundant.

2. P. media. L. (Hoary Plantain.)

Meadows and pastures. 6-10.

Near the Canal at Greenford, also at Pinner Wood. (F. W. Longman.) Waxwell, Pinner. 
3. P. lanceolata. L. (Ribwort Plantain.)

Meadows and pastures. 6, 7 .

Common everywhere.

4. P. Coronopus. L. (Buck's Horn Plantain.)

Barren, heathy, or gravelly soils. 6, 7.

Sparingly on Harrow Weald Common and Stanmore Heath.

\section{LITTORELLA. (Shoreweed.)}

I. L. lacustris. L. (Plantain Shoreweed.) Margins of lakes. 6, 7 .

Ruislip Reservoir. Found by Rev. E. Brewer, 10th July, 1872.

This plant, which was supposed to be extinct, has been happily recovered to the County of Middlesex.

SUb-Crass IV. MONOCHLAMYDEA.

Order LXX. ChenopodiaceA. (Goose-foot Tribe.)

\section{CHENOPODIUM. (Goose-foot.)}

I. C. olidum. Curt. (Stinking goosefoot.) Waste places by roadsides. 8,9 .

A troublesome weed in the garden of Pinner Parsonage.

2. C. polyspermum. L. (Many-seeded Goose-foot.) Waste places and among rubbish. 8, 9 . Gardens at Harrow and Pinner.

B. C. acutifolium. Sm. The Cemetery, Pinner.

3. C. album. L. (White Goose-foot.)

Waste places, etc. 7-9. 
a. C. candicans. Lam.

Frequent at Harrow and Pinner. Horsington Hill. (Flor. Midd.)

B. C. viride. L.

Pinner. Near Alperton. (Flor. Midd.)

4. C. ficifolium. Sm. (Fig-leaved Goose-foot.)

Waste ground. 8, 9.

Not common. Farm yard at Kenton, and in a field at Roxeth. For several years at the Marsh, Pinner; now extinct. Alperton. (Flor. Midd.)

5. C. glaucum. L. (Oak-leaved Goose-foot.) Waste ground, in sandy soil especially. 8, 9.

Growing with $C$. ficifolium in a Farm yard at Kenton, and also at Roxeth.

6. C. rubrum. L. (Red Goose-foot.)

Dunghills and waste places. 8, 9 .

Not unfrequent in waste ground at Harrow. Down fields and gardens at Pinner. Near Alperton. (Flor.Midd.)

7. C. Bonus Henricus. L. (Good King Henry, or Mercury Goose-foot, Wild Spinach.)

Waste places and way sides. 5-8.

Bank by the Grove kitchen garden wall, opposite Rev. F. Rendall's house. Stanmore. (Varenne.)

\section{ATRIPLEX. (Orache.)}

I. A. hastata. Bab. (Spreading Halberd-leaved Orache.) Cultivated and waste ground. 6-10. Everywhere common.

2. A. deltoidea. Bab. (Triangular-leaved Orache.) Cultivated and waste ground. 6-10. 
Occurs as a weed in neglected ground, such as near the Roxborough turnpike, etc.

3. A. angustifolia. Bab. (Spreading Narrow-leaved Orache.)

Waste ground. 7-10.

Corn-fields at Wood End. Gardens and road sides at Pinner.

4. A. erecta. Huds. (Upright Spear-leaved Orache.) Corn-fields. 7-10.

Wood End; Northolt and Woodhall, Pinner. Horsington Hill. (Flor. Midd.)

Order LXXi. SCleranthaceÆ. (Knawel Tribe.)

\section{SCLERAN'THUS. (Knawel.)}

I S. annuus. L. (Annual Knawel.)

Corn-fields. 7,8 .

Pinner. Harrow Weald Common. (Flor. Midd.)

Order lXXit. polygonace e. (Persicaria Tribe.)

POLYGONUM. (Persicaria, Knot Grass, Buckwheat, and Bistort.)

I. P. Bistorta. L. (Common Bistort, or Snakeweed.) Moist Meadows. 6-9.

On the inner grassy slope of the Moat at Headstone, Pinner. Terrilands, Pinner. Near Ruislip Reservoir. (Flor. Midd.)

2. P. aviculare. L. (Common Knot Grass.)

Waste places and way sides. 5-9.

Abundant. A very variable plant. 
3. P. Fagopyrum.* L. (Buck Wheat.)

Cultivated land. 6, 7.

Corn-field, Pinner Hill-1872.

4. P. Convolvulus. L. (Climbing Buckwheat, Black Bindweed.)

Corn-fields. 7-9.

Wood End.

5. P. amphibium. L. (Amphibious Red Persicaria.) Margins of lakes and ponds. 7,8.

Canal, near Greenford, and Ruislip Reservoir.

6. P. Persicaria. L. (Spotted-leaved Persicaria.)

Waste places. 7-10.

Very common everywhere.

7. P. lapathifolium. L. (Pale-flowered Persicaria.)

Fields and waste places.

Occurs throughout the district.

8. P. maculatum. Dyer.

Damp gravelly places. 7-9.

Waste heap at Greenford, by the Canal, sparingly.

9. P. Hydropiper. L. (Biting Persicaria.)

Sides of ditches. 8,9 .

Very frequent.

\section{RUMEX. (Dock and Sorrel.)}

I. R. Hydrolapathum. Huds. (Great Water Dock.) Ditches and river sides. 7, 8. Frequent by the side of the Canal.

2. R. crispus. L. (Curled-leaved Dock.) Way sides, and near houses. 6-8. 
Peterborough Road, Harrow, Headstone Drive, waste ground near the Three Horse Shoes tavern, Roxeth, etc.

3. R. obtusifolius. L. (Broad-leaved Dock.) Way sides and waste places. 7-9. Abundant.

4. R. sanguineus. L. (Bloody-reined Dock.) Woods and road sides. 7,8 . Pinner Hill.

ß. R. viridis. Sibth. (Green-veined Dock.) Pinner Wood.

5. R. conglomeratus. Murr. (Sharp Dock.) Watery places, etc. $6-8$.

Pastures, etc., at Harrow, not unfrequent.

6. R. acetosa. L. (Common Sorrel.) Meadows and pastures. 5-7.

Very common.

7. R. acetosella. L. (Sheep Sorrel.) Dry pastures. $\quad 5-7$.

Harrow Weald and Ruislip Commons, at Greenhill, Headstone Drive, Peterborough Road, etc.

Order LXXiti. thymelacele. (Mezereon Tribe.)

\section{DAPHNE. (Spurge Laurel.)}

I. D. Laureola.* L. (Common Green Spurge Laurel.) Woods and Thickets. 1-5.

I found one plant in Harrow Park. (Edition i.) Cannons, Whitchurch. 
Order lXXVII. EUPhorbiace

\section{MERCURIALIS. (Dog's Mercury.)}

I. M. perennis. L. (Perennial or Dog's Mercury.) Woods and shady places. 3-5.

Roxeth. Horsington Lane in abundance. Frequent in Pinner and Ruislip Woods.

2. M. annua.* L. (Annual Mercury.)

Waste and cultivated land. 8, 9 .

Pinner. A single plant in the Parsonage Garden. September, 1872.

\section{EUPHORBIA. (Spurge.)}

I. E. Helioscopia. L. (Sun Spurge.)

Waste and cultivated ground. 6-10.

Gardens, etc., at Harrow and Pinner, frequent.

2. E. platyphylla.* L. (Broad-leaved Warted Spurge.) Corn-fields, etc. 6-10.

A single plant was found on the road side between Harrow and Eastcott, and no others were seen in the neighbourhood, though perhaps if the ploughed land on the other side of the hedge had been examined, a further supply might have been obtained. Stanmore. (Varenne.)

3. E. Peplus. L. (Petty Spurge.)

Cultivated and waste ground. 7-11.

Abundant as a weed in the gardens at Harrow and Pinner, and on waste heaps.

4. exigua. L. (Dwarf Spurge.)

Corn-fields. 7-10.

At Wood End and Pinner. 


\section{E. Lathyris.* L. (Caper Spurge.)}

Thickets, and as a weed in gardens. 6, 7 .

Gardens at Roxeth and Pinner, occurring as a weed; and Grove Garden, Harrow. The seeds form a dangerous substitute for capers, which are the buds of the exotic Capparis spinosa. L.

6. E. amygdaloides. L. (Wood Spurge.)

Woods and thickets. 3-6.

Pinner and Ruislip Woods; Horsington Lane, thickets at Greenford; Roxeth, by footpath to Rifle butts. Stanmore. (Varenne.)

Order LXXVIII. CALlitrichace A. (Water Starwort TRIBE.)

\section{CALLITRICHE. (Water Starwort.)}

r. C. verna. L. (Vernal Water Starwort.) Ditches and pools. 4-9. Abundant everywhere; a very variable plant.

2. C. stagnalis. Scop. (Broad-fruited Water Starwort.) Usually on mud. 5-9.

Harrow. Eastcott; Harrow Weald Common. (Flor. Midd.)

3. C. hamulata. Kütz. (Falcate Water Starwort.) Lakes and streams. 6-9.

In the main feeder of Ruislip Reservoir. The plant is of a rigid compact habit; and by this, as well as its falcate bracts, may be distinguished from other species. 
Order LXXIX. CERATOPHYLLACEA. (Hornwort Tribe.)

\section{CERATOPHYLLUM. (Hornwort.)}

I. C. demersum. L. (Common Hornwort.) Streams and ditches. 6,7 .

Harrow Pond,"stagnant ponds at Roxeth and Ruislip, etc. Headstone Moat. Brook by Forty Farm. (Farrar.)

Order LXXX. URTICACEA. (Nettle Tribe.)

\section{URTICA. (Nettle)}

I. U. urens. L. (Small Nettle.)

Waste places and cultivated ground. 6-9.

Frequent at Harrow. Sparingly at Pinner.

2. U. dioica. L. (Great Stinging Nettle.)

Waste places. 6-9.

Abundant everywhere.

\section{HUMULUS. (Hop.)}

I. H. Lupulus. L. (Common Hop.)

Thickets and hedges. 7, 8 .

Hedges near the Cricket Ground; at Roxeth; at Love Lane, Pinner, and at Alperton.

\section{PARIETARIA. (Pellitory.)}

I. P. officinalis. L. (Common Pellitory of the Wall.) Old walls. 6-9.

Pinner Church Wall. This is the P. diffusa, Koch.

[Cannabis sativa, L., or Common Hemp, is occasionally found in places where it has escaped from cultivation, but it is not recognized as an English plant.] 
Order lXXXi. Ulmace

\section{ULMUS. ( $E l m$.)}

1. U. suberosa.* Ehrh. (Common Elm.) Woods and hedges. 3-5.

Very common. The prevailing timber tree of the district.

ß. U. glabra. Sm. (Smooth-leaved Elm.) Harrow Weald. Cannons Park. (Flor. Midd.)

2. U. montana. Bauh. (Wych Elm, or Broad-leaved Elm.)

Woods and hedges. 3, 4 .

Grove, Harrow; Harrow Park; also in hedges in Harrow and Pinner. Stanmore and Harrow Weald. (Flor. Midd.)

ß. U. major.* Sm. (Dutch Elm.) Eastcott.

Order LXXXiv. BetulaceÆ. (Brrch Tribe.)

I. Betula alba. L. (Common Birch.)

Woods. 4,5 .

Not unfrequent in plantations, etc., at Harrow. Pinner Hill; Harrow Weald Common.

Order lXXXV. SAlicacea. (Whlow Tribe.)

SALIX. (Willow, Sallow, Osier.)

I. S. triandra. L. (Blunt Stipuled Triandrous Willow.) Banks of rivers and ditches. 4-6. Bank of River Brent, near Alperton. 
r. S. amygdalina. L. (Almond-leaved Willow.) By the Brent, between Greenford and Perivale. (Lees.)

2. S. fragilis. L. (Crack Willow.)

Marshy woods and osier grounds. 4, 5 .

a. S. decipiens: Hoffm.

In a hedge on the Northolt Road, Roxeth.

$\beta$. S. fragilis. L.

Hedgerows at Harrow.

. S. Russelliana. Sm. (Bedford Willow.)

3. S. alba. L. (White Willow.)

Wet places.

Hedges at Harrow; plantations at Pinner.

$\gamma$. S. vitellina. (Yellow Willow, or Golden Osier.)

Hedges and osier grounds, etc. 5 .

Pool in sand pit at Pinner. The Hall, Pinner.

4. S. repens. L. (Creeping Willow.)

Moist and dry heaths, etc. 4, 5 .

In abundance on Harrow Weald and Stanmore Commons, where occur both the varieties, S. fusca, Sm. (Dwarf Silky Willow), and S. prostrata, Sm. (Prostrate Silky Willow).

5. S. viminalis. L. (Common Osier.)

Wet places and osier grounds. 4, 5 .

Common at Harrow.

6. S. Smithiana. Willd. (Silky-leaved Osier.)

Meadows and osier grounds. 4, 5 .

Near Pinner Drive, where it has been probably planted; abundant in a copse at Pinner Park.

7. S. cinerea. L. (Gray Sallow.) 
Banks of rivers, wet hedge rows. 3,4 .

Very common. S. aquatica, Sm., and S. oleifolia, Sm., are varieties of this plant, which have been found in hedgerows at Roxeth.

8. S. caprea. L. (Great Round-leaved Sallow, or Goat Willow.)

Woods and hedgerows. 4, 5 .

Abundant in the hedges at Harrow, Alperton, Pinner Hill, Northolt, and Ruislip. The catkins, which are bright yellow, appear about Palm Sunday, and are often called Palms on that account.

\section{POPULUS.}

I. P. alba. (Great White Abele, or Poplar.)

Moist and mountain woods. 3, 4 .

Pinner Hill; the Grove, Harrow.

2. P. canescens.* Sm. (Grey Poplar.)

Damp Woods. 3, 4 .

Pinner Place. Most likely introduced.

3. P. tremula.* L. (Aspen.)

Woods. 4.

Sudbury? Harrow Weald Common; Stanmore. (Flor. Midd.)

4. P. nigra.* L. (Black Poplar.)

Damp ground. 3.

The Hall and other places about Pinner. Probably planted.

Order lXXXVi. CUPUlifera. (OAK Tribe.)

FAGUS. (Beech.)

I. F. sylvatica. L. (Common Beech.) 
Woods and plantations. 4,5 .

The Grove, Harrow; Harrow Park, and other plantations at Harrow. Pinner Wood; The Hall, Pinner.

\section{QUERCUS. (Oak.)}

I. Q. robur. L. (Common British Oak.)

Woods and hedges. 4,5 .

Abundant.

\section{CASTANEA. (Chestnut.)}

I. C. vulgaris. Lam. (Spanish Chestnut.)

Woods and plantations. 5-7.

The Grove, Harrow, and Harrow Park. Pinner Hill.

[We may as well here notice that Asculus hippocastanum or Horse Chestnut, of the natural order Hippocastanea; and not, as might be expected, belonging to the Chestnut tribe, is not indigenous.]

\section{ALNUS. (Alder.)}

I. A. glutinosa.* Gært. (Common Alder.)

Wet places. 3.

The Hall and Ash Hill, Pinner; and at Harrow Weald. Probably not wild. Apparently indigenous at Ruislip.

\section{CORYLUS. (Hazel.)}

I. C. Avellana. L. (Common Hazel Nut.)

Hedges and copses. 5 .

Abundant at Harrow; Pinner Wood, Horsington Hill. (Flor. Midd.)

\section{CARPINUS. (Hornbeam.)}

I. C. Betulus.* L. (Common Hornbeam.)

Woods and hedges. 5.

Pinner Wood; Woodhali ; also occuring in plantations at Harrow. Kingsbury. (Farrar.) 
Order lXXXVII. CONiferA. (Cone-bearing Tribe.)

\section{PINUS. (Fir.)}

I. P. sylvestris.* L. (Scotch Fir.)

Woods and plantations. 5,6 .

The Grove, Harrow; plantations at Harrow Weald Park, etc. Young plants are found growing on Harrow Weald Common, no doubt from seeds wafted from the adjoining plantations.

\section{TAXUS. (Yew.)}

I. T. baccata. L. (Common red-berried Yew.)

Woods. 3, 4.

Thickets in the Grove, Harrow; thoroughly naturalized there. Pinner churchyard, planted. 


\title{
CLASS II.
}

\section{MONYCOTYLEDONES OR ENDOGENOUS FLOWERING PLANTS.}

\author{
SUB-CLASS I. PETALOIDEF.
}

ORder LXXXVIII. HYDROCHARIDACEAE. (FrogbIT TrIBE.)

\section{ANACHARIS. (Anacharis.)}

I. A. Alsinastrum.* Bab. (Common Anacharis, or Pondweed.) Elodea Canadensis (Mich.*)

Ponds, ditches, canals, and streams. 7-10.

Canal at Greenford. Abundant. Ruislip Reservoir, pond near Stanmore. This American species first made its appearance some years ago, we believe about the year 1849 , but is now alarmingly increasing year by year, and too generally diffused to be eradicated. There are huge beds of it in the Canal, which yearly increase in size.

\section{HYDROCHARIS. (Frogbit.)}

I. H. Morsus-ranæ. L. (Common Frogbit.)

Ditches and ponds. 7,8.

Pond at Forty Farm; Wembley Park. (Cole.) 
Order lXXXix. Orchidaceat. (Orchis Tribe.)

\section{LISTERA. (Twayblade.)}

I. L. ovata. Br. (Common Green-flowered Twayblade.) Woods and moist pastures. 5-7.

South end of the Grove, Harrow, Bentley Priory Woods, Stanmore, and Pinner.

2. L. Nidus-avis. Hook. (Common Bird's-nest.) Shady woods. 6 .

Copse in Headstone Lane, Pinner. Harrow Grove. (Farrar.) Grounds of Stanmore Cottage. (Varenne.)

\section{ORCHIS. (Orchis.)}

I. O. Morio. L. (Green-wing Meadow Orchis.) Meadows and pastures. 5, 6 . Pastures at Roxeth and Pinner. Abundant. On Ruislip Moor, plentiful. (Flor. Midd.)

2. O. mascula. L. (Early purple Orchis.) Woods and pastures. 5 . In a copse between Pinner Wood and Oxhey Farm.

3. O. maculata. L. (Spotted Palmate Orchis.) Pastures and heaths. 5-7.

The Grove, Harrow, Harrow Park, and Harrow Weald Common. At the last-mentioned place very fine specimens are found.

\section{HABENARIA. (Frog Orchis.)}

I. H. viridis. R. Br. (Green Frog Orchis.) Pastures. 6, 7 .

Pinner Hill. Discovered June 1871, by W. A. Tooke, Esq., and in a second locality in 1872 . 


\section{SPIRANTHES. (Lady's Tresses.)}

I. S. autumnalis. Rich. (Fragrant Lady's Tresses.)

Dry, chalky, and gravelly places. 8,9 .

Pastures, Pinner Hill (Mrs. Tooke).

\section{EPIPACTIS. (Helleborine.)}

I. E. media. Fries. (Broad-leaved Helleborine.)

Woods and plantations. 7, 8 .

The Parsonage Grounds, Harrow Weald; Pinner Wood.

ORDER XC. IRIDACEA. (IrIS Tribe.)

IRIS. (Iris, Flower-de-Luce.)

I. I. Pseudacorus. L. (Yellow Water Iris, or Flag.) Watery places, sides of rivers. 5-8.

Side of Canal at Greenford, Grove Pond, Harrow, and near Kenton, by the side of a pond.

OrDer XCI. AMARYLLIDACEA. (Amarylus Tribe.)

NARCISSUS. (Narcissus, Daffodil.)

I. N. Pseudo Narcissus.* L. (Common Yellow Daffodil.)

Moist woods and thickets. 3,4 .

In pastures at Roxeth; very plentiful at Pinner Hill and Pinner Green. Probably not indigenous.

2. N. biflorus.* Curt. (Pale Two-flowered Narcissus.) Pastures. 4, 5 . 
Waste ground by Mrs. Rotch's house, at the bottom of the hill; it has been probably planted there, or an outcast from the adjoining garden. Pinner Green, with No. 1. Ruislip. (Flor. Midd.)

3. N. poeticus.* L.

Heathy fields. 5 .

Meadow at Pinner Hill; likely escaped from a garden. (Mrs. Tooke.)

ORDER XCII. DIOSCOREACEA. (YaM TRIBE.)

\section{TAMUS. (Black Bryony.)}

I. T. communis. L. (Common Black Bryony.)

Hedges and thickets. 5,6 .

Very common. In all parts of the district. Not to be confounded with the Bryonia dioica, or Red-berried Bryony, which is also frequent in the hedges.

Order XCIII. Trillitace a. (Herb Paris Tribe.)

\section{PARIS. (Herb Paris.)}

I. P. quadrifolia. L. (Common Herb Paris, True - Love Knot, One Berry.)

Moist and wet shady woods. 5, 6 . Abundant in a copse near Pinner Wood.

Order XCIV. LILIACEA. (Limy Tribe.)

\section{ENDYMION.}

I. E. nutans. Dumort. (Common Bluebell, or Wild Hyacinth.)

Woods, hedgerows, and copses. 4-6. 
Pinner Wood, Harrow, Grove, Football Field, at Roxeth, etc. Occasionally with white flowers. Also called Agraphis nutans, Link, Scilla, Sm., and Hyacinthus nonscriptus, L.

\section{ALLIUM. (Garlick, Leek, Onion.)}

\section{A. vineale. L. (Crow Garlick, or Onion.)}

Corn-fields and waste places. 6,7 .

Meadows at Roxeth, where also grows the variety A. compactum, Thuill, in which the umbel is composed of bulbs only, without flowers.

2. A. ursinum. L. (Broad-leaved Garlick, or Ramsons.) Moist woods and hedge banks. 4-6.

Bank on Pinner Road, hedges near Sudbury, near a foot-crossing on the Railroad, Pinner; in a lane, and at Bentley Priory, Harrow Weald.

\section{FRITILLARIA. (Fritillary.)}

I. F. Meleagris. L. (Common Fritillary, Snake's Head Lily, or Chequered Daffodil.)

Meadows and pastures. 5 .

In fields at Pinner, in one of which it is very abundant, and frequently occurs with white flowers.

\section{TULIPA. (Tulip.)}

I. T. sylvestris.* L. (Wild Tulip.)

Chalk pits. 4,5. Colour, yellow without stripes or markings.

In a meadow at Roxeth, where it has flowered on several occasions. Entered with great doubt as to its authenticity, as the Editor has never seen a verified specimen with which to compare it. Found by Mrs. Parr. 
Order XCVII. JUNCACE

\section{JUNCUS. (Rush.)}

I. J. effusus. L. (Soft Rush.)

Marshy ground. 7,8.

Abundant everywhere in swampy places.

2. J. conglomeratus. L. (Compact-headed Rush.)

Marshy ground. 7, 8 .

Ditches at Harrow and Harrow Weald Common; Pinner.

Stanmore Heath. (Flor. Midd.)

3. J. glaucus. Ehrh. (Hard Rush.)

Wet pastures and by road sides.

Very Common.

4. J. diffusus. Hoppe.

In wet places, rare. 7,8 .

Porridge-pot Hill, Pinner, discovered 8th August, 1871.

5. J. acutiflorus. Ehrh. (Sharp-flowered Jointed Rush.)

Bogs and marshy ground. 6-8.

Abundant on Harrow Weald Common, and on swampy ground throughout the district.

6. J. lamprocarpus. Ehrh. (Shining-fruited Jointed Rush.)

Boggy grounds and watery places. 7-8.

Headstone Drive, Harrow Weald Common.

7. J. uliginosus. Sibth. (Lesser Bog Jointed Rush.) Boggy and swampy places. 6-8. Harrow Weald Common. Stanmore Heath. (Flor. 
8. J. compressus. Jacq. (Round-fruited Rush.)

Damp places. 6-8.

Stanmore. (Varenne.)

9. J. bufonius. L. (Toad Rush.)

Moist watery places. 8,9 .

Not uncommon by the road sides and ditches at Harrow, Pinner, Ruislip, etc.

I0. J. squarrosus. L. (Heath Rush.)

Moors and heaths. 6, 7.

Harrow Weald Common, abundant. Stanmore Heath. (Flor. Midd.)

\section{LUZULA. (Wood Rush.)}

I. L. sylvatica. Bich. (Great Hairy Wood Rush.)

Woods and hilly places. 5,6 .

Pinner Wood.

2. L. pilosa. Willd. (Broad-leaved Hairy Wood Rush.) Woods. 3-5.

Pinner Wood and Horsington Wood. Ruislip Woods. (Flor. Midd.)

3. L. Forsteri. DC. (Narrow-leaved Hairy Wood Rush.)

Groves and thickets, etc.

Harrow Weald, woods at Pinner.

4. L. campestris. Willd. (Field Wood Rush.)

Woods and dry pastures. 4, 5 .

Abundant.

5. L. multiflora. Lej. (Many-flowered Woodrush.)

Moist and turfy ground. 6.

Pinner Hill, Harrow Weald Common. Stanmore

Heath. (Flor. Midd.) 
Order XCVitI. Butomace e. (Flowering Rush Tribe.)

BUTOMUS. (Flowering Rush.)

I. B. umbellatus. L. (Common Flowering Rush.)

Ditches and ponds.

Canal near Greenford, also pond at Roxeth. The Brent. (Lees.)

Order XCiX. alismace e. (Water Plantain Tribe.)

\section{ALISMA. (Water Plantain.)}

I. A. Plantago. L. (Greater Water Plantain.)

Margins of ponds or rivers. $6-8$.

Frequent. Canal, Harrow Pond, Grove Pond, etc. At Ruislip Reservoir and Alperton is found the narrowleaved variety, A. lanceolatum, With.

\section{SAGITTARIA. (Arrow Head.)}

I. S. sagittifolia. L. (Common Arrow Head.)

Ditches and margins of rivers. 7-9.

Frequent in the Canal by Greenford. Alperton; Wembley. (Cole.) Stonebridge; Forty Farm. (Farrar.)

Order C. JUngaginace E. (Arrow Grass Tribe.)

TRIGLOCHIN. (Arrow Grass.)

I. T. palustre. L. (Marsh Arrow Grass.)

Sides of rivers and ditches. 6-8.

Side of Canal at Greenford. Near the Brent. (Lees.) 
Order CI. TyPhaCE

TYPHA. (Cat's Tail, or Reed Mace.)

I. T. angustifolia. L. (Lesser Reed Mace.)

Pools and ditches.' 7, 8.

Side of Ruislip Reservoir.

2. T. latifolia. L. (Great Reed Mace, or Common Cat's Tail.)

Borders of ponds and lakes. 7, 8 .

Canal at Greenford. In a pool near Pinner Wood and at the Woodridings, Pinner. Between Whitchurch and Stanmore. (Flor. Midd.) This plant is sometimes called Bullrush, though erroneously, the true Bullrush being Scirpus Lacustris.

\section{SPARGANIUM. (Bur-reed.)}

I. S. ramosum. Huds. (Branched Bur-reed.)

Banks of Ditches and lakes. 7.

Side of Canal at Greenford, ponds at Harrow and Roxeth, and marshy ground by Ruislip Reservoir. Stanmore. (Flor. Midd.)

2. S. simplex. Huds.

Ditches. 7.

In a feeder to Ruislip Reservoir. Pools at Perivale. (Lees.)

\section{Order CII. ARACEAe. (ARUM Tribe.)}

\section{ACORUS. (Sweet Flag.)}

I. A. Calamus. L. (Common Sweet Flag.)

By the side of rivers. 6-7.

Greenford. (Cooper.) 
ARUM. (Arum, Cuckoo-pint.)

I. A. maculatum. L. (Cuckoo-pint, Wake Robin, Lords and Ladies.)

Groves and hedges. 4, 5 .

Very common in all the hedges.

Order CIV. PISTIACE E. (Duckweed Tribe.)

LEMNA. (Duckweed.)

I. L. trisulca. L. (Ivy-leaved Duckweed.).

Clear stagnant waters. 7,8 .

Grove Pond, Harrow; Harrow Park Lake. Pond in Payne's Lane, Pinner.

2. L. minor. L. (Lesser Duckweed.)

Stagnant waters. 7,8 .

Everywhere abundant.

3. L. polyrrhiza. L. (Greater Duckweed.)

Stagnant waters. It never flowers in Britain.

Pond at Harrow. Brook in Moll Cobb's Lane, Pinner.

4. L. gibba. L. (Gibbous Duckweed.)

Stagnant waters. 6.9.

Ponds at Roxeth. With the last in Moll Cobb's Lane, Pinner. Greenford Road. (Farrar.) Harrow Weald. (Flor. Midd.)

Order CV. NaIAdace A. (Pondweed Tribe.)

POTAMOGETON. (Pondweed.)

I. P. densus. L. (Opposite-leaved Pondweed.)

Ditches and rivers. 6,7 . 
Canal at Greenford. Stanmore. (Flor. Midd.) It must not be confounded with the similar Anacharis Alsinastrum, which chiefly differs by its having three leaves in a whorl instead of two opposite ones.

2. P. pectinatus. L. (Fennel-leaved Pondweed.)

Ponds and streams. 6, 7 .

Canal at Greenford; Ruislip Reservoir. Canal at Alperton. (F'lor. Midd.)

3. P. pusillus. L. (Small Linear-leaved Pondweed.) Ditches and still waters. 6,7 .

Abundant in the Canal at Greenford, pond by Headstone Drive.

4. P. compressus. L.

Ditches and ponds. 7 .

Harrow Weald. (Edition i.)

5. P. crispus. L. (Curled-leaved Pondweed.)

Ditches and rivers. 6, 7 .

Kenton; Grove Pond, Harrow; Lake in Harrow Park, most abundant; Canal, Greenford; and ponds at Roxeth; near Waxwell, Pinner. Stanmore. (Flor. Midd.)

6. P. perfoliatus. L. (Perfoliate Pondweed.)

Ditches and lakes. 7.

Canal at Greenford and Alperton.

7. P. natans. L. (Sharp-fruited Broad-leaved Pondweed.)

Stagnant waters and slow streams. 6, 7 .

Everywhere abundant. Harrow Weald. (Flor. Midd.)

Perivale. (Lees.) 
8. P. oblongus. Viv. (Oblong-leaved Pondweed.)

Ditches, small streams, and ponds. 7.

In a ditch at Harrow Weald Common, which is so entirely covered by its floating leaves that you could not possibly tell that water was underneath.

\section{ZANNICHELLIA. (Horned Pordweed.)}

I. Z. palustris. L. (Common Horned Pondweed.)

Stagnant pools, ponds, and ditches. 5-8.

Ponds at The Poplars, and Payne's Lane, Pinner.

\section{Sub-Class II. GLUMaCEe.}

Order cVi. cyperaceie. (Gauingate or Sedge Tribe.)

\section{ELEOCHARIS. (Spike Rush.)}

I. E. palustris. Br. (Creeping Spike Rush.) Sides of ditches and marshy places. 6, 7.

Harrow Weald Common By the Canal, Alperton. (Newbould.) By the Brent. (Lees.)

2. E. acicularis. Sm. (Least Spike Rush.) Moist or muddy ground. 7,8.

Ruislip Reservoir.

This plant forms a green covering to the bottom of the reservoir when the water is drawn off in a dry summer.

3. E. fluitans. L. (Floating Spike Rush.)

Ditches and pools. 6,7 .

Piece of open ground called Whitchurch Common, at the back of Canon's Park, between Stanmore and Edgware. 1827-30.

(Varenne.) 
SCIRPUS. (Club Rush.)

I. S. sylvaticus. L. (Wood Club Rush.)

Moist woods and banks of rivers. 7 .

Canal at Northolt. At Alperton. (Newbould.) By the Brent, Perivale. (Lees.)

2. S. lacustris. L. (Bullrush.)

Rivers and ponds. 6,7 .

In a pool close to the Canal near Northolt; Ruislip Reservoir. Canal, Alperton. (Newbould.) The Brent, Kingsbury. (Flor. Midd.)

\section{CAREX. (Sedge.)}

I. C. ovalis. Gooden. (Oval-Spiked Sedge.)

Bogs and marshy places. 6,7 .

Fields near Harrow Weald, Harrow Weald Common, and Headstone Drive.

2. C. stellulata. Gooden. (Little Prickly Sedge, Starry Sedge.)

Marshy and heathy places. 5,6 .

Harrow Weald Common, abundant; Pinner. Stanmore Heath. (Flor. Midd.)

3. C. remota. L. (Distant-spiked Sedge.)

Woods and moist shady places. 6,7 .

Pinner, frequent; Harrow Park, the Grove, and hedges on the Kenton road. Stanmore. (Varenne.)

4. C. axillaris. Good. (Axillary Clustered Sedge.) Marshes, rare. 6.

Ditch on east side of the road from Harrow Railway Station to Harrow Weald. (Flor. Midd.) 
5. C. vulpina. (Great Sedge.)

Wet shady places. 6,7 .

Common by the side of the Canal at Greenford, in ditches at Kenton, Pinner, and throughout the district.

6. C. paniculata. L. (Great panicled Sedge.)

Muddy ditches and bogs. 6.

Stonebridge. (Farrar.) Canal, Alperton, 1867, sparingly. (Newbould.)

7. C. divulsa. Gooden. (Gray Sedge.)

Moist shady pastures. 5,6 .

Edge of a pool at Roxeth, and Oxhey Farm, Pinner; rare. Woodhall, Pinner; Harrow Weald. (Flor. Midd.)

8. C. muricata. L. (Greater Prickly Sedge.)

Marshy and gravelly pastures. 5,6 .

Common at Harrow, Headstone Drive, Pinner Churchyard. Near Pinner Railway Station; Harrow Weald. (Flor. Midd.)

9. C. acuta. L. (Slender Spiked Sedge.)

Wet places. 6 .

Canal, Alperton. (Newbould.)

ro. C. vulgaris. Fries. (Common Sedge.)

Marshes and wet pastures. 5,6 .

Not uncommon in the meadows at Harrow and Pinner.

Harrow Weald and Stanmore Commons. (Flor. Midd.)

II. C. flava. L. (Yellow Sedge.)

Turfy bogs. 6,7 .

Harrow Weald Common. Stanmore Heath. (Flor.Midd.)

12. C. pallescens. L. (Pale Sedge.)

Marshy places. 6.

Near the Lake, Bentley Priory, Harrow Weald. 
13. C. binervis. Sm. (Green-ribbed Sedge.)

Dry heaths and moors.

Harrow Weald Common, also sparingly on Ruislip Common. Stanmore Heath. (Flor. Midd.)

I4. C. lævigata. Sm. (Smooth Stalked beaked Sedge.) Marshy copses, rare. 6.

Wet places on Stanmore Heath. (Varenne.)

I5. C. panicea. L. (Pink Leaved Sedge.)

Marshy places. 6.

Common in moist meadows at Harrow, Pinner, and Harrow Weald. Stanmore Heath. (Flor. Midd.)

I6. C. sylvatica. Huds. (Pendulous Wood Sedge.) Moist woods. 5,6 .

Abundant in Harrow Park; Bentley Priory Woods, near Stanmore.

I7. C. strigosa. Huds. (Loose Pendulous Sedge.) Groves and thickets. Rare. 5, 6 .

Moss Lane, Pinner.

r8. C. pendula. Huds. (Great Pendulous Sedge.)

Moist woods and shady places, 5, 6 .

Woods at Pinner and Alperton; the Grove, Harrow; and Bentley Priory Woods, Stanmore.

Ig. C. pseudo-Cyperus. L. (Cyperus-like Sedge.)

Damp places, rare. 6 .

Stanmore, in a grove opposite Drummond's House. (Herb. G. and R. in Flor. Midd.)

20. C. glauca. Scop. (Glaucous Heath Sedge.)

Moist meadows. 6,7 .

Meadows at Harrow, Pinner, Harrow Weald Common. Stanmore Heath. (Varenne.) 
2I. C. præcox. Jacq. (Vernal Sedge.)

Dry pastures and heaths. 4, 5 .

Near Greenford, Ruislip Common, Pinner Hill, meadows at Pinner.

22. C. pilulifera. L. (Round-headed Sedge.)

Moory ground. 6, 7 .

Harrow Weald Common; dry banks at Pinner Hill. Stanmore Heath. (Flor. Midd.)

23. C. hirta. L. (Hairy Sedge.)

Wet pastures and woods. 5,6 .

Pastures at Kenton, Pinner Hill, Woodridings, Bentley Priory, and Harrow. Stanmore Heath. (Flor. Midd.)

24. C. vesicaria. L. (Short-spiked Bladder Sedge.) Wet bogs. 5 .

In boggy ground near Ruislip Reservoir. The Brent near Willesden. (Herb. Hardw. in Flor. Midd.)

25. C. paludosa. Gooden. (Lesser Common Sedge.) Banks of rivers and ditches. 5, 6 .

Side of Canal, Greenford, abundant. Ruislip Moor. (Flor. Midd.)

Between Stanmore and Harrow Weald. (Herb. G. and R. in Flor. Midd.)

26. C. riparia. Curt. (Great Common Sedge.)

Sides of rivers and ditches. 5,6 .

Greenford, side of Canal. 
Order CVII. Gramine.e. (Grass Tribe.)

\section{ANTHOXANTHUM. (Vernal Grass.)}

I. A. odoratum. L. (Sweet-scented Vernal Grass.) Meadows and pastures. 5-7.

Abundant. Its scent, when drying, gives the agreeable smell to new-made hay. Johnston, in his "Chemistry of Common Life," observes, "This grass contains coumarin, and imparts to dry hay the odour of this substance." The Asperula odorata, L. (Sweet Woodruff), and the Melilotus officinalis, L. (Common Melilot), also contain coumarin, and when dried emit a fragrant odour. (Edition i.)

\section{NARDUS. (Mat Grass.)}

I. N. stricta. L. (Common Mat Grass.) Moors and heaths. 6.

Abundant on Harrow Weald Common. Stanmore Heath. (Flor. Midd.)

\section{ALOPECURUS. (Foxtail Grass.)}

I. A. agrestis. L. (Slender Foxtail Grass.)

Fields and way sides. 5-11.

Cultivated ground at Greenford, and at Stanmore. Near Harrow Station; Horsington Hill. (Flor. Midd.)

2. A. pratensis. L. (Meadow Foxtail Grass.) Meadows and pastures. 5, 6 . Everywhere abundant.

3. A. geniculatus. L. (Floating Foxtail Grass.) By pools and wet places. 5-8.

Ditches at Kenton; by the Canal; and at Roxeth. Harrow Weald and Stanmore Commons. (Flor. Midd.) 
4. A. fulvus. Sm. (Orange-spiked Foxtail Grass.)

Wet margins of ponds, ditches, and watery places. 6-9. Edge of Ruislip Reservoir.

\section{PHALARIS. (Canary Grass.)}

I. P. Canariensis.* L. (Cultivated Canary Grass.)

Waste heaps; an outcast from cultivation. 7, 8. ,

Common on a heap at Greenford; near the Canal; also by the turnpike at the end of the Northwick walk, Harrow. It sometimes occurs as a weed in the gardens at Harrow.

2. P. arundinacea. L. (Reed Canary Grass.)

Sides of lakes and rivers. 7,8 .

Canal; abundant; by Ruislip Reservoir; the Brook, Pinner. The variety with leaves variegated with white lines, called ribbon grass, striped grass, or gardener's garters, is common in gardens. (Edition i.)

\section{PHLEUM. (Cat's Tail Grass.)}

I. P. pratense. L. (Common Cat's Tail Grass, or Timothy Grass.)

Meadows and pastures. 6-10.

Abundant; named Timothy Grass in honour of Mr. Timothy Hanson, who cultivated it extensively in America.

\section{MILIUM. (Millet Grass.)}

I. M. effusum. L. (Spreading Millet Grass.) Moist shady woods. 5,6 . Thickets at Wood End.

\section{POLYPOGON. (Beard Grass.)}

I. P. monspeliensis.* Desf. (Annual Beard Grass.) Moist pastures near the sea. 7,8 . 
Woodridings, Pinner. August, 1871. In a field at Roxborough. (Farrar.)

\section{AGROSTIS. (Bent Grass.)}

\section{A. canina. L. (Brown Bent Grass.)}

Moist heaths and moory places. 6, 7 .

Frequent at Harrow Weald Common; Bank of Ruislip Reservoir. Stanmore Heath. (Flor. Midd.)

2. A. vulgaris. With. (Fine Bent Grass.) Meadows, pastures, and banks. 6, 7 .

Common everywhere.

ß. A. pumila. Lightf. Harrow Weald Common. (Flor. Midd.)

3. A. alba. L. (Marsh Bent Grass.)

Pastures and road sides. 7, 8.

Very common; similar to the last, and united to it by Mr. Bentham.

4. A. Spica-Venti.* L. (Spreading Silky Bent Grass.) Sandy fields. 6,7 .

Rare; road side at Roxeth; Pinner Churchyard. Waste heaps, Alperton. (Flor. Midd.)

\section{AIRA. (Hair Grass.)}

I. A. cæspitosa. L. (Tufted Hair Grass.) Moist shady places, and borders of fields. 6, 7 . Abundant.

2. A. flexuosa. L. (Waved Hair Grass.) Heaths, and hilly places. 7,8 . Abundant on Harrow Weald Common; Pinner Hill. Stanmore Heath. (Flor. Midd.) 
3. A. præcox. L. (Early Hair Grass.)

Heaths and sandy places. 5,6 .

Pinner Hill. Harrow Weald Common. (Flor. Midd.)

\section{MOLINIA. (Molinia.)}

I. M. cœrulea. Mœnch. (Purple Molinia.)

Wet heathy places and moors. $7,8$.

Harrow Weald Common.

MELICA. (Melick Grass.)

I. M. uniflora. Retz. (Wood Melick Grass.)

Shady woods. 5-7.

Abundant in Harrow Park, near the ruins.

\section{HOLCUS. (Soft Grass.)}

r. H. mollis. L. (Creeping Soft Grass.)

Pastures and hedges. 7, 8.

Borders of fields at Roxeth. Harrow Weald and Stanmore Commons. (Flor. Midd.)

2. H. lanatus. L. (Pink Soft Grass.)

Meadows and pastures. 6,7 .

Abundant.

\section{ARUNDO. (Reed.)}

I. A. Phragmites. L. (Common Reed.)

Damp places, sides of streams. 8 .

Pinner, near Woodridings; near Northolt; Ruislip

Reservoir.

\section{ARRHENATHERUM. (False Oat Grass.)}

I. A. avenaceum. Beauv. (Common False Oat Grass.) Hedges and pastures. 6, 7.

Very common. A. elatius, M. and K. 
B. A. bulbosum. Lindl. On dry banks at Pinner Hill.

\section{PANICUM. (Panick Grass.)}

I. P. Crus-galli.* L. (Loose Panick Grass.) Cultivated ground. 7.

Waste heaps by the Canal, Alperton. (Flor. Midd.)

[2. P. miliaceum. L. (Millet Panick Grass.)

Waste heaps by the Canal, Alperton, 1867. (Flor. Midd.)]

\section{SETARIA. (Bristle Grass.)}

I. S. viridis.* Beauv. (Green Bristle Grass.) Fields. 7, 8 .

Dungheap in a field between Sudbury Station and Alperton. (Flor. Midd.)

2. S. glauca.* Beauv. (Glaucous Bristle Grass.) Waste heap by Canal, Alperton. (Flor. Midd.)

[3. S. italica. Beauv. (Millet.)

A few plants on waste heap by Canal, Alperton, 1867. (Flor. Midd.)]

\section{GLYCERIA. (Manna Grass.)}

I. G. aquatica. Sm. (Reed Manna Grass.) Sides of rivers, ponds, and ditches. 7,8. Very common at the Canal near Greenford. Eastcott.

2. G. fluitans. R. Br. (True Manna Croup Grass.) Ditches and pools. 7, 8 .

Very common.

3. G. plicata. Fries. (Plicate Manna Croup Grass.) Muddy pools and ditches. $6-8$. 


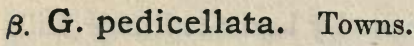
Eastcott. (Flor. Midd.)

4. G. rigida. L. (Hard Manna Grass.)

Old walls. 6,7 .

Kitchen garden wall at the Grove, Harrow; abundant ; also on an old wall at Headstone Farm.

\section{POA. (Meadow Grass.)}

I. P. pratensis. L. (Smooth-stalked Meadow Grass.) Meadows and pastures. 6, 7 .

Abundant.

2. P. trivialis. L. (Rough-stalked Meadow Grass.) Meadows and Pastures. 6, 7. Very common.

3. P. nemoralis. L. (Wood Meadow Grass.)

Woods, thickets, and pastures. 6, 7 .

Not uncommon in Harrow Park, meadows at Roxeth, and a copse at Headstone. Moss Lane, Pinner. (Flor. Midd.)

4. P. annua. L. (Annual Meadow Grass.)

Meadows and pastures, and by road sides. 4-11.

Everywhere most abundant.

\section{TRIODIA. (Heath Grass.)}

I. T. decumbens. Beauv. (Decumbent Heath Grass.)

Heaths and moors. 7,8.

Abundant on Harrow Weald Common. Stanmore Heath. (Flor. Midd.)

\section{BRIZA. (Quaking Grass.)}

x. B. media. L. (Common Quaking Grass.)

Meadows and pastures. 6,7 . 
Meadows at Roxeth and Kenton; Pinner; by Northwick walk, Harrow, and in the Football Field. One of the most elegant of our British grasses. (Edition i.)

\section{DACTYLIS. (Cock's-foot Grass.)}

I. D. glomerate. L. (Common Cock's-foot Grass.)

Way sides, meadows, and woods. 6,7 .

Very common.

\section{CYNOSURUS. (Dog's-tail Grass.)}

I. C. cristatus. L. (Crested Dog's-tail Grass.)

Dry Pastures. 7, 8.

Abundant in all pastures.

\section{FESTUCA. (Fescue Grass.)}

I. F. Myurus. L. (Capon's-tail Grass.)

On old walls. 6 .

Garden wall at the Grove, and old wall at Headstone Farm, in both cases growing with Poa rigida.

2. F. ovina. L. (Sheep's Fescue Grass.)

Dry pastures. 6, 7 .

Dry banks at Northolt. Harrow Weald and Stanmore Commons. (Flor. Midd.)

3. F. duriuscula. L. (Hard Fescue Grass.) Heaths and dry banks. 6.

Roxeth. Harrow Weald Common. (Flor. Midd.)

4. F. pratensis. Huds. (Meadow Fescue Grass.) Moist meadows and pastures. 6, 7 .

Very common. 
$\beta$. F. loliacea. Huds.

In pastures at Harrow and Pinner. Alperton. (Newbould.)

5. F. gigantea. Vill. (Tall-bearded Fescue Grass.) Shady woods and moist hedges. 7, 8 . Abundant in Harrow Park, and the Grove, Harrow. This is the Bromus giganteus, $\mathrm{L}$.

6. F. arundinacea. Schreb. (Reedy Fescue Grass.) Banks and sides of streams. 6,7 .

Near a small stream, where it is crossed by the footpath through the Football Field from Harrow to Sudbury. By Canal near Alperton. (Newbould.)

\section{BROMUS. (Brome Grass.)}

I. B. asper. L. (Hairy Wood Brome Grass.) Moist woods and hedges. 6, 7 .

Very common at Harrow; at Pinner. Harrow Weald; near Alperton; Horsington Hill. (Flor. Midd.)

2. B. sterilis. L. (Barren Brome Grass.) Waste ground, fields, and hedges. 6, 7. Frequent everywhere.

3. B. racemosus. L.? (Smooth Brome Grass.) Meadows and pastures. 6, 7 .

Harrow Weald. (Flor. Midd.)

4. B. commutatus. Schrad. (Tumid Field Brome Grass.)

- Road sides and fields. 6,7 .

Frequent. Very similar to the following, but usually glabrous. 
5. B. mollis. L. (Soft Brome Grass.)

Meadows, pastures, and waste ground. 5, 6 .

Everywhere abundant.

\section{AVENA. (Oat Grass.)}

I. A. fatua.* 'L. (Wild Oat, or Haver.)

Corn-fields and waste ground. 6-8.

Waste heap at Canal, and at Horsington. Perivale. (Lees.)

2. A. flavescens. L. (Yellow Oat Grass.) Trisetum flavescens. P. de Beauv.

Dry meadows and pastures. 7, 8 .

Not unfrequent at Harrow, Pinner, and throughout the district.

\section{HORDEUM. (Barley.)}

I. H. pratense. Huds. (Meadow Barley.)

Moist meadows and pastures. 6, 7.

Very common. Not to be confounded with the next, which is never found in pastures.

2. H. murinum. L. (Wall or Mouse Barley, Way Bennet.)

Waste ground, by walls and road sides. 6, 7 .

Harrow Station Bridge, road side at Roxeth. Near Pinner Station.

\section{TRITICUM. (Wheat, Wheat Grass.)}

I. T. repens. L. (Creeping Wheat Grass, or Couch Grass.)

Fields and waste places. 6-8.

Everywhere abundant. 


\section{BRACHYPODIUM. (False Brome Grass.)}

r. B. sylvaticum. Beam. (Slender False BromeGrass.) Borders of fields and hedges. 6, 7 .

At Roxeth, hedges on the Kenton Road, etc., not unfrequent. Hedge banks at Pinner. Near Pinner Wood; Edgware. (Flor. Midd.)

\section{LOLIUM. (Rye Grass.)}

I. L. perenne. L. (Perennial or Beardless Rye Grass.) Pastures and way sides. 6,7 .

Very common.

2. L. temulentum.* L. (Darnel, Bearded Rye Grass.) Corn-fields and waste places. 6-8.

Waste heap at the Canal, road side on the Kenton Road, waste ground at Alperton.

[3. L. italicum.* A. Braun. (Italian Rye Grass.)

Cultivated fields. 6 .

In a meadow and the copse adjoining Headstone Lane, Pinner. Introduced for agricultural purposes.] 


\section{CLASS III.}

\section{ACOTYLEDONOUS OR FLOWERLESS PLANTS.}

\section{Sub-Class I. Fillces. (Fern Tribe.)}

Order CVIII. POLYPODIACEA. (PolyPodiom OR Fern TrIBE.)

\section{POLYPODIUM. (Polypody.)}

I. P. vulgare. L. (Common Polypody.)

Rocks, walls, trunks of trees. 6-9.

Hedge banks at Pinner; Wood End.

\section{POLYSTICHUM. (Prickly Fern.)}

I. P. aculeatum. Newm. (Common Prickly Fern.) Moist woods and hedge banks.

Banks at Pinner, near the Station road. Moss Lane, Pinner. (Flor. Midd.)

2. P. angulare. Willd. (Angular-leaved Shield Fern.) Woods and hedge banks. 7,8 . Lane leading from Pinner to Harrow Weald. (Edition i.) Headstone Lane, Pinner. 


\section{LASTRFA. (Buckler Fern.)}

I. L. Oreopteris. Presl. (Sweet Mountain Fern.) Mountain heaths. 7.

Harrow Weald Common. (Rev. B. F. Westcott.)

2. L. Filix-Mas. Presl. (Common Male Fern.)

Woods and shady banks. 6, 7 .

Harrow Park, the Grove, Pinner Wood, frequent. Harrow Weald Common and Stanmore Heath. (Flor. Midd.)

3. L. dilatata. Presl. (Broad prickly-toothed Buckler Fern.)

Moist woods and moors. 8,9 .

Pinner Wood. Harrow Weald Common. Stanmore Heath. (Herts. Fl. Supp.)

\section{CYSTOPTERIS. (Bladder Fern.)}

\section{C. fragilis. Bernh. (Brittle Bladder Fern.)}

Rocks and walls. 7 .

On a low damp wall at Pinner Hill. This interesting plant was discovered June 2nd, 1871, in company with W. A. Tooke, Esq.

\section{ATHYRIUM. (Lady Fern.)}

I. A. Filix-fœmina. Roth.

Wet shady places. 6,7 .

In an enclosure near Harrow Weald Common. (Mr.

T. Wilkinson.) Stanmore. (Varenne in Flor. Midd.)

\section{ASPLENIUM. (Spleenwort.)}

I. A. Adiantum-nigrum. L. (Black Spleenwort.) Rocks and walls. 6-9. 
On a hedge bank, Harrow Weald. (Mr. T. Wilkinson.) Headstone Lane, Pinner. (Mrs. W. G. Stuart.)

2. A. Trichomanes. L. (Maiden Hair Spleenwort.) Rocks and walls. 5-10.

Garden wall, Sudbury. (T. Wilkinson.)

3. A. Ruta-muraria. L. (Wall Rue.)

Old walls. 6-8.

Pinner Church wall; old wall at Greenford, near the Church.

\section{SCOLOPENDRIUM. (Hart's Tongue.)}

I. S. vulgare. Sym. (Common Hart's Tongue.) Shady banks and rocks. 7, 8 .

On the Rickmansworth Road. Hedges between Stanmore and Harrow. (Edition i.) Pinner, plentiful in 1869, rare in 1875 .

\section{PTERIS. (Brake.)}

I. P. aquilina. L. (Common Brake, or Bracken.) Woods and heaths. 7, 8.

Harrow Weald. Pinner Hill. Several seedling plants occurred on the walls at Mr. Green's Nursery, Pinner.

\section{BLECHNUM. (Hard Fiern.)}

'I. B. boreale. Sw. (Northern Hard Fern.)

Woods and heaths. 7, 8.

Harrow Weald Common. A well-marked variety of this, entered as $B$. anomalum, also occurs. 
Order CX. OPhioglossace.e. (Adder's Tongue Tribe.)

\section{OPHIOGLOSSUM. (Adder's Tongue.)}

r. O. vulgatum. L. (Common Adder's Tongue.)

Moist pastures. 5,6 .

Football Field, Harrow ; and abundant in a field at Greenford. (Edition i.) Roxeth; Pinner Hill. Ruislip Moor. (Flor. Midd.)

Order CXIII. EQUiSAtTacea. (Horsetail.)

\section{EQUISETUM. (Horsetail.)}

r. E. Telmateia. Ehrh. (Great Water Horsetail.) Wet damp ground. 4,5 .

Bentley Priory, Harrow Weald.

2. E. arvense. L. (Corn Horsetail.)

Corn-fields and road sides. 4,5 .

Abundant.

3. E. limosum. L. (Smooth Naked Horsetail.)

Sides of rivers. 6,7 .

Ruislip Reservoir, and ditches on Ruislip Common. Stanmore Heath. (Flor. Midd.)

4. E. palustre. L. (Marsh Horsetail.) Boggy soils. 6,7 .

Side of the Canal, near Greenford.

5. E. sylvaticum. L. (Branched Wood Horsetail.) Moist woods, and hedge banks. 4, 5 .

Abundant on Harrow Weald Common. An unfrequent and peculiarly graceful species. 


\section{Order CXIV. CHARACEAE.}

\section{CHARA.}

I. C. syncarpa. Thuil.

Ruislip Reservoir.

2. C. vulgaris. L.

Pools at Alperton, Woodridings and Roxeth.

3. C. fragilis. Desv.

Small pond at Pinner Hill; brook at Eastcott; Ruislip Reservoir.

\section{APPENDIX.}

Plants not found in the Harrow district, but occurring between it and the Colne.

I. Helleborus viridis. L. Mr. Eley's Wood, Oxhey. (A. Cottam.)

2. Rubus Schlechtendalii. W. and N. Woods near Pinner Lane. (Fl. Herts. Supp.)

3. R. fusco-ater. Weihe. Woods near Pinner Lane. (Fl. Herts. Supp.)

4. R. Guntheri. Weihe. Woods by Pinner Lane. (Fl. Herts. Supp.)

5. R. hirtus. W. and $K$. Woods near Pinner Lane. (Fl. Herts. Supp.) 
6. Rosa inodora. Fr. Oxhey Lane.

(R. A. Pryor.)

7. Epilobium palustre. L. Bacher Heath. (R. A. Pryor.)

8. Hippuris vulgaris. L. The Colne, Hamper Mill.

9. Saxifraga granulata. L. Fields by Hamper Mill. (A. Cottam.)

10. Enanthe fluviatilis. Colem. The Colne, Hamper Mill.

II. Cichorium Intybus. L. Near Hamper Mill. (Mrs. Tooke.)

12. Vaccinium Myrtillus. L. Eastbury.

13. Symphytum officinale. L. The Colne, Hamper Mill; Moor Park.

I4. Lamium amplexicaule. L. Near Wiggenhall. (A. Cottam.)

I5. L. incisum. Willd.

Wiggenhall. (A. Cottam.)

I6. Pinguicula vulgaris. L. Watford Common Moor. (R. A. Pryor.)

I7. Centunculus minimus. L. Moor Park. (R. A. Pryor.) 


\section{APPENDIX.}

18. Salix rugosa. Leefe.

Near Hamper Mill. (R. A. Pryor.)

I9. Habenaria bifolia. R. Br.

Watford Heath.

20. Convallaria majalis.' L.

Nanscot Wood.

2I. Lolium arvense. With.

Little Oxhey Lane.

22. Lastrea spinulosa. Presl.

Oxhey Wood.

NoTE.-W. A. Tooke, Esq., has lately found a new station for Listera Nidus-avis at Pinner Hill.

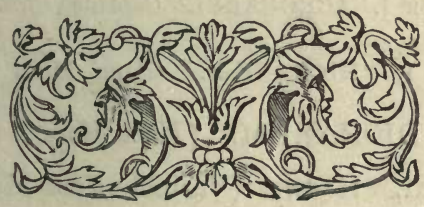




\section{MUSCI. MOSSES.}

Order I. SPHAGNace 7 . (Bog Moss Tribe.)

\section{SPHAGNUM. (Bog Moss.)}

I. S. cymbifolium. Ehrh. (Boat-leaved Bog Moss.) Harrow Weald Common.

2. S. acutifolium. Ehrh. (Long-leaved floating Bog Moss.)

Harrow Weald Common.

Order it. bryacez. (Thread Moss t'ribe.)

Section I. ACROCARPI. Capsules terminal.

SUb-Order I. DICRANEA. (Fork Moss Division.)

DICRANUM. (Fork Moss.)

I. D. varium. Hedw. (Variable Fork Moss.) Harrow Weald.

2. D. heteromallum. Hedw. (Silky-leaved Fork Moss.)

Harrow Weald.

3. D. scoparium. Hedw. (Broom Fork Moss.) Pinner Wood. 
4. D. majus. Turn. (Greater Fork Moss.)

Pinner.

\section{LEUCOBRYUM. (White Fork Moss.)}

r. L. glaucum. B. and S. (White Fork Moss.) Harrow Weald Common.

CERATODON. (Horn-tooth Moss.)

I. C. purpureus. Brid. (Purple Horn-tooth Moss.) Harrow Weald.

Sub-Order II. POTtiea. (Pottia Division.) POTTIA.

I. P. truncata. B. and S. (Truncated Pottia.) Harrow.

Sub-Order III. TRIChOSTOMEA. (Fringe Moss Division.) DIDYMODON. (Twin-tooth Moss.)

I. D. rubellus. B. and S. (Purple Twin-tooth Moss.) Harrow and Pinner.

\section{TORTULA. (Screw Moss.)}

I. T. unguiculata. Hedw. (Bird's-claw Screw Moss.) Harrow Weald.

2. T. fallax. Hedw. (Fallacious Screw Moss.) Ruislip.

3. T. muralis. Hedw. (Wall Screw Moss.) Pinner; Harrow. 
4. T. subulata. Bridel. (Awl-shaped Screw Moss.) Pinner.

5. T. ruralis. Hedw. (Great Hairy Screw Moss.) Pinner.

Sub-Order IV. GRIMmeÆ. (Grimma Division.)

\section{GRIMMIA.}

I. G. pulvinata. Smith. (Grey Cushioned Grimmia.) Pinner; Harrow Weald.

Sub-Order V. ORThOTRIChe A. (Bristle Moss Division.) ORTHOTRICHUM. (Bristle Moss.)

I. O. affine. Schrad. (Pale Straight-leaved Bristle Moss.)

Pinner.

2. O. crispum. Hedw. (Curled Bristle Moss.) Pinner.

Sub-Order VI. POLYTRICheÆ. (Hatr Moss Division.) ATRICHUM. (Hairless Moss.)

I. A. undulatum. P. Beauv. (Undulated Hairless Moss.)

Pinner; Harrow.

POGONATUM. (Bearded Moss.)

I. P. aloides. Bridel. (Dwarf Aloe-like Bearded Moss.)

Pinner Wood; Harrow Weald. 


\section{BRYEA. \\ POLYTRICHUM. (Hair Moss.)}

I. P. commune. L. (Common Hair Moss.)

Pinner Wood.

2. P. juniperinum. Hedw. (Juniper-leaved Hair Moss.)

Harrow Weald; Pinner.

Sub-Order VII. BRYEA. (Thread Moss Division.)

BRYUM. (Thread Moss.)

I. B. nutans. Schreb. (Pendulous Thread Moss.) Pinner.

2. B. capillare. Hedw. (Matted Thread Moss.) Pinner.

3. B. cæspiticium. L. (Lesser Matted Thread Moss.) Pinner.

4. B. argenteum. L. (Silvery Thread Moss.) Pinner.

\section{MNIUM. (Thyme Thread Moss.)}

I. M. rostratum. Schwægr. (Long-beaked Thyme Thread Moss.)

Harrow Weald.

2. M. hornum. Hedw. (Swan's-neck Thyme Thread Moss.)

Pinner.

3. M. undulatum. Hedw. (Long-leaved Thyme Thread Moss.)

Pinner; Harrow. 
Sub-Order Vili. FUNARIE

\section{FUNARIA. (Cord Moss.)}

I. F. hygrometrica. Hedw. (Hygrometric Cord Moss.) Pinner; Harrow.

Sub-Order IX. Fissidente FISSIDENS. (Cleft-tooth Moss.)

I. F. bryoides. Hedw. (Lesser pinnate Cleft-tooth Moss.)

Pinner; Harrow.

2. F. taxifolius. Hedw. (Yew-leaved Cleft-tooth Moss.) Harrow.

Section III. PLEUROCaRPI. Capsules lateral.

Sub-Order X. Leucodonte瓜. Pale-tooth Moss Division.

\section{LEUCODON. (Pale-tooth Moss.)}

I. L. sciurioides. Schwægr. (Squirrel-tail Pale-tooth Moss.)

Pinner; Harrow.

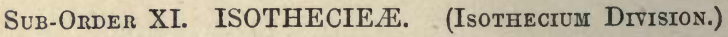

\section{ISOTHECIUM.}

I. I. myosuroides. Bridel. (Mouse-tail Isothecium.) Harrow.

2. I. alopecurum. Wils. (Fox-tail Isotbecium.)

Harrow. (Thamnium; Bry. Brit.) 


\section{LESKEA.}

I. L. polycarpa. Ehrh. (Long-headed Leskea.)

Harrow Weald.

2. L. sericea., Hedw. (Silky Leskea.)

Harrow.

Sub-Order XII. hypneA. (Feather Moss Division.)

\section{HYPNUM. (Feather Moss.)}

I. H. glareosum. Bruch. (Gravelly Feather Moss.) Harrow.

2. H. lutescens. Huds. (Rough-stalked yellow Feather Moss.)

Pinner.

3. H. rutabulum. L. (Common Rough-stalked Feather Moss.)

Harrow.

4. H. prælongum. L. (Very long Feather Moss.)

Harrow.

5. H. striatum. Schreb. (Common Striated Feather Moss.)

Pinner.

6. H. ruscifolium. Neck. (Long-beaked Water Feather Moss.)

Harrow.

7. H. serpens. L. (Creeping White-veiled Feather Moss.)

Harrow. 
8. H. riparium. L. (Short-beaked Water Feather Moss.)

Pinner.

9. H. cordifolium. Hedw. (Heart-leaved Feather Moss.)

Harrow; Pinner.

ro. H. cuspidatum. L. (Pointed Bog Feather Moss.) Harrow Weald Common.

II. H. Schreberi. Willd. (Schreber's Feather Moss.) Pinner.

I2. H. purum. L. (Neat Meadow Feather Moss.) Harrow Weald.

I3. H. tamariscinum. Hedw. (Proliferous Feather Moss.)

Pinner.

I4. H. triquetrum. L. (Triquetrous Feather Moss.) Harrow.

15. H. loreum. L. (Rambling Mountain Feather Moss.)

Pinner; Harrow.

r6. H. squarrosum. L. (Drooping-leaved Feather Moss.)

Harrow; Pinner.

I7. H. fluitans. L. (Floating Feather Moss.)

Alperton; Harrow ; Pinner.

18. H. uncinatum. Hedw. (Sickle-leaved Feather Moss.)

Harrow Weald. 
I9. H. cupressiforme. L. (Cypress-leaved Feather Moss.)

Harrow.

20. H. undulatum. L. (Wavy Feather Moss.) Pinner.

2I. H. sylvaticum. L. (Wood Feather Moss.) Harrow.

22. H. denticulatum. L. (Sharp Fern-like Feather Moss.)

Harrow Weald.

SUb-Order XIII. OMALIEE. (OMaLia Division.)

NECKERA.

I. N. complanata. Bryol. Eur. (Flat Neckera.) Harrow; Pinner.

Sub-Order XIV. FONTINALEA. (Water Moss Division.)

FONTINALIS. (Water Moss.)

I. F. antipyretica. L. (Greater Water Moss.) Harrow; Ruislip.

\section{HEPATICAE. (Liverworts.) \\ JUNGERMANNIACEE.}

I. Scapania undulata. Nees. Harrow Weald Common.

2. Plagiochila asplenioides. N. and M. Pinner. 
3. Jungermannia crenulata. Sm. Harrow Weald Common.

4. Lophocolea bidentata. Nees. Pinner Wood.

5. L. heterophylla. Nees. Pinner Wood.

6. Calypogeia Trichomanes. Cord. Pinner Wood.

7. Martinellia complanata. Gray. Pinner Wood.

8. Frullania dilatata. Nees. Harrow; Pinner Wood.

9. Pellia calycina. Nees. Harrow.

ro. P. epiphylla. Nees. Harrow Weald Common.

\section{Marchantiacee.}

I. Marchantia polymorpha. L. Pinner.

\section{Ricciace e.}

I. Riccia fluitans. L. In pools at Harrow and Pinner. 


\section{BIRDS OF HARROW.}

FALCONIDE.

KESTREL. (Falco tinnunculus.)

SPARROW HAWK. (Falco nisus.)

A nest of the Sparrow Hawk was taken in the Mount, during the spring of 1861 , situated at the top of a Scotch fir.

Found at Ruislip June 3rd, 1875.

\section{MERLIN. (Falco øalon.) \\ HOBBY. (Falco subbuteo.) \\ BUZZARD. (Falco buteo.)}

Of these five the two first only have come under my own immediate notice, but the others have been occasionally seen about here.

\section{STRIGID E.}

Of this tribe there are only two representatives here:

BARN OWL. (Strix flammea.)

BROWN OWL. (Strix aluco.)

A nest of this bird was found in the Grove, in the hollow of a tree, during the spring of 1862 . 


\section{LANIADE.}

\section{RED-BACKED SHRIKE. (Lanius collurio.)}

\section{Very common.}

The Red-Backed Shrike, or Butcher bird, is by no means uncommon at Harrow, though a rare visitor in the midland counties, and scarcely ever seen in the north of England. It first arrives in this neighbourhood towards the end of April or beginning of May, and leaves it again in September. The food of this bird consists of cockchafers, beetles, grasshoppers, and such like insects; it also occasionally makes a meal of a small bird; its food is impaled on thorns previous to being eaten. I have found an unfledged bird impaled in this manner, half devoured, which shows that even nests are not safe from the depredations of these well-named Butcher birds.

\section{MUSCICAPIDÆ.}

\section{SPOTTED FLYCATCHER. (Muscicapa Griseola.)}

This bird is very common here.

\section{PIED FLYCATCHER. (Muscicapa atricapilla.)}

I know of one authenticated instance of the occurrence of this rare bird here: a nest with three eggs was taken in the Grove, about the year 1836, and the eggs are still preserved.

None since 1873.

\section{T UR D I D 蚱.}




\section{FIELDFARE. (Turdus pilaris.)}

This bird is only a visitor here, remaining with us during the winter months, and departing northwards for breeding purposes about the beginning or middle of April.

\section{SONG THRUSH. (Turdus musicus.)}

\section{Common.}

On the 24th of May, 1862, I found an egg of this bird near Pinner Drive, perfectly spotless.

\section{REDWING. (Turdus iliacus.)}

This bird, like the Fieldfare, only remains with us during the winter, departing in March.

\section{BLACKBIRD. (Turdus merula.)}

$$
\text { P.A RID E. }
$$

Of the seven species which compose this tribe, I have noticed five at Harrow.

\section{GREAT TITMOUSE. (Parus major.)}

Very common.

BLUE TITMOUSE. (Parus cœruleus.)

Common.

\section{COLE TITMOUSE. (Parus ater.)}

I found a nest of this bird in a hole in a barn, during the spring of 1862, containing young birds nearly fledged.

One since 1873. Park. (R. B. H.) 


\section{MARSH TITMOUSE. (Parus palustris.)}

One in Harrow Grove, three years ago. (R. B. H.) None since 1873.

\section{LONG-TAILED TITMOUSE. (Parus caudatus.)}

One or two, Harrow Weald.

I found a nest of the Bumbarrel, as the Long-tailed Tit is called, in this neighbourhood, in the Football Field, towards the end of March, 1863.

\section{SYLVIA D $\mathbb{E}$.}

HEDGESPARROW. (Accentor modularis.)

ROBIN. (Sylvia rubecula.) REDSTART. (Sylvia phœnicurus.) STONECHAT. (Sylvia rubicola.) WHINCHAT. (Sylvia rubetra.)

The Whinchat, as well as the Stonechat, is very common here during the summer, and may be seen in almost every field. A favourite situation for their nests is the banks of the Railway, where they build in large numbers.

\section{WHEATEAR. (Sylvia œnanthe.)}

Two seen near Mutton Lane, March, 1875.

\section{GRASSHOPPER WARBLER. (Sylvia locustella.)}

I found, during the spring of 1861 , a nest of this bird, situated in some low brambles; it contained six eggs slightly incubated, five of which are still in my possession.

None since 1873. 


\section{SEDGE WARBLER. (Sylvia phragmitis.)}

Not common.

During the spring of 1860 , I obtained a nest of this bird, containing two eggs, at the old Duck-puddle.

Two nests found near Pinner, 1875.

\section{NIGHTINGALE. (Sylvia luscinia.)}

Pretty common.

Nightingales are very plentiful here in the summer time, and I have found several of their nests every year.

\section{BLACKCAP. (Sylvia atricapilla.)}

Pretty common. Pinner Lane, Oxhey Wood, etc. To be found in most of the copses about here.

\section{GARDEN WARBLER. (Sylvia hortensis.)}

Occasional. Harrow Weald.

\section{WHITETHROAT. (Sylvia cinerea.)}

Very common.

\section{LESSER WHITETHROAT. (Sylvia curruca.)}

Common.

Nearly as common as the Greater Whitethroat.

\section{WOOD WREN. (Sylvia sibilatrix.)}

Rare, but occasionally met with.

None since 1873 . 


\section{WILLOW WREN. (Sylvia trochylus.)}

Common.

CHIFF-CHAFF. (Sylvia rufa.)

Oxhey Wood, fairly common.

GOLDEN-CRESTED REGULUS. (Regulus cristatus.)

MOTACILLID E.

PIED WAGTAIL. (Motacilla Yarellii.)

Occasional.

RAY'S WAGTAIL. (Motacilla campestris.)

Near Pinner Road, one nest, 1875.

Frequently met with in pairs during the summer months.

A N T HID

TREE PIPIT. (Anthus arboreus.)

Oxhey Wood. Common.

\section{MEADOW PIPIT. (Anthus pratensis.)}

Very common, and are caught in large numbers by the birdcatcher.

\section{ROCK PIPIT. (Anthus obscurus.)}

A specimen of the Rock Pipit was caught by the birdcatcher here during November, 1862; being uncertain 
what kind of pipit this was, I skinned it and took some trouble to discover its right name, it proved to be without doubt the Anthus obscurus. The Rock Pipit though common on the sea coast is very rarely seen so far inland as Harrow.

None since 1873.

A L A U D I D Æ.

SKY LARK. (Alauda arvensis.)

Common.

WOOD LARK. (Alauda arborea.)

EMBERIZIDA.

COMMON BUNTING. (Emberiza millearia.)

Occasionally met with, though not common.

BLACK-HEADED BUNTING. (Emberiza Schoniclus.)

Common.

YELLOW HAMMER. (Emberiza citrinella.)

FRINGILLIDÆ.

CHAFFINCH. (Fringilla calebs.)

BRAMBLING. (Fringilla montifringilla.)

Caught occasionally by the birdeatcher during the flight time.

None since 1873. 
TREE SPARROW. (Fringilla montana.)

Uncommon, but seen occasionally in small flocks during the winter.

HOUSE SPARROW. (Fringilla domestica.) Common.

GREENFINCH. (Fringilla chloris.)

Common.

\section{HAWFINCH. (Fringilla cocothraustes.)}

This neighbourhood seems to be rather a favourite place of resort for these birds, though they are not common in most places, and they seem to be rather on the increase than the contrary. On the 7th of May, 1863, I saw a nest of the Hawfinch situated at the top of a tall apple tree in the Grove, containing five eggs; it was composed of small sticks and twigs, slightly lined with hay and one or two feathers.

One found since 1873. (Mr. Stuart's.)

\section{GOLDFINCH. (Fringilla carduelis.)}

None since 1873.

SISKIN. (Fringilla spinus.)

Do not breed here.

LINNET. (Fringilla cannabina.)

Common.

LESSER REDPOLE. (Fringilla linaria.)

Very common during the winter. Does not breed in general here. 


\section{MEALY REDPOLE. (Fringilla borealis.)}

Not common, although some are seen most years during the winter, and are occasionally caught.

\section{TWITE. (Fringilla montium.)}

Occasionally caught during the months of October, November, and December, when they arrive here from the north.

\section{BULLFINCH. (Loxia pyrrhula.)}

\section{Common.}

A pied Bullfinch was caught here during the winter of 1862 ; it was a hen bird, with patches of white about the crown of the head and both wings.

\section{CROSSBILL. (Loxia curvirostra.)}

A female Crossbill was caught alive here during September, 1863, by A. Fuller, Esq.

\section{STURNID 世.}

\section{STARLING. (Sturnus vulgaris.)}

Very common.

$$
\text { C O R V I D E. }
$$

\section{CROW. (Corvus corone.)}

Common. Very numerous about here.

$$
\text { ROOK. (Corvus frugilegus.) }
$$

Common. 


\section{JACKDAW. (Corvus monedula.)}

Not very common.

\section{MAGPIE. (Corvus pica.)}

Occasional. Two since 1873, near the Range.

Not very common close round Harrow, owing to the scarcity of covers.

\section{JAY. (Corvus glandarius.).}

Jays are frequently seen in the Park, where nearly every year a nest is built.

P I C I D $\mathbb{E}$.

GREEN WOODPECKER. (Picus viridis.) LESSER SPOTTED WOODPECKER. (Picus minor.)

Specimens of both the Green and Lesser-spotted Woodpeckers were shot by Edward Palmer, when gardener to the late Mr. Cunningham.

Often heard in spring in Harrow Grove and in Dr. Butler's Garden. Makes a sound exactly like that of a tree creaking when it is about to fall.

\section{WRYNECK. (Yunx torquilla.)}

Not uncommon. The country people call it "Cuckoo's mate."

CERTHIAD卌.

CREEPER. (Certhia familiaris.)

Occasional. 


\section{WREN. (Troglodytes Europaus.)}

Common.

\section{NUTHATCH. (Sitta Europæa.)}

Fairly common. Common where any large trees are found.

C U C ULID Æ.

CUCKOO. (Cuculus canorus.)

Common.

\section{HALCYONID A.}

KINGFISHER. (Alcedo ispida.)

Rare; but occasionally seen in the Park. Three since 1873.

HIRUNDINID压.

SWALLOW. (Hirundo rustica.)

Common.

MARTIN. (Hirundo urbica.)

Common.

SAND MARTIN. (Hirundo riparia.)

Seldom seen close round Harrow; the nearest place where they build is the Chalk Pits, at Pinner.

o 2 


\section{SWIFT. (Cypselus apus.)}

Common; several pairs build here every year. There are usually one or two nests in Mr. Chapman's barn; some also build in the Church steeple.

Common at Pinner and Ruislip.

COLUMBIDA.

RING DOVE. (Columba palumbus.)

Occasional.

STOCK DOVE. (Columba cenas.)

TURTLE DOVE. (Columba turtur.)

Rare. The Park and Oxhey Wood.

PHASIANID \&.

PHEASANT. (Phasianus Colchicus.)

TETRAONID正.

PARTRIDGE. (Perdix cinerea.)

Fairly common.

RED-LEGGED PARTRIDGE. (Perdix $r u f a$.)

Found at Ruislip, June 3rd, 1875. 
CHA RA D RIID A.

\section{LAPWING. (Vanellus cristatus.)}

Common.

A R DEID E.

HERON. (Ardea cinerea.)

Two seen in 1875. (J. C.)

Occasionally seen flying at a great height. I have never seen one settle.

I have seen three pairs in the last ten years.

SCOLOPACID A.

WOODCOCK. (Scolopax rusticola.)

Very seldom seen about here.

None since 1873 .

COMMON SNIPE. (Scolopax gallinago.)

One in 1875 . (J. C.)

\section{JACK SNIPE. (Scolopax gallinula.)}

Both the common and Jack Snipe used to be plentifully found in the meadow land round here, but since the improvements in draining they are seldom met with.

None since 1873.

R A L I D Æ.

LAND RAIL. (Gallinula crex.)

Very common; the Football Field is a favourite resort for them, and on a summer's evening several may be heard 
calling to one another at the same time, with their harsh grating note.

\section{MOORHEN. (Gallinula chloropus.)}

Common.

ANATID无.

\section{WILD DUCK. (Anas boscas.)}

Four at Ruislip. Two near the Rifle Range. Not frequently seen. Five seen near Range, 1875. Seven seen at Moor Park, 1876. (J. C.)

\section{TEAL. (Anas Crecca.)}

Of rare occurrence. A nest found at Oxhey Pond in 1875.

\section{COOT. (Fulica atra.)}

Moor Park and Ruislip.

CAPRIMULGID压.

NIGHT JAR. (Caprimulgus Europæus.)

Three nests at Oxhey. One seen in the garden of the Knoll, Harrow, in June, 1875.

COLYMBID E.

DAB-CHICK. (Colymbus Hebridicus.)

Rare: a nest found at Oxhey in 1875 . 


\section{BUTTERFLIES.}

(Those marked with $a$ * are additions to the list.)

Latin Name.

Pieris Brassicæ

" Rapæ .

"Napi

Anthocharis Cardamine Gonepteryx Rhamni.. Colias Edusa..
English Name.

.. Cabbage Butterfly.

.. Small White.

.. Green-reined.

.. Orange-tip.

. Brimstone.

.. Clouded Yellow.

\section{Found at Pinner Drive.}

Argynnis Paphia .. .. Silver-washed Fritillary.*

Saw one specimen in 1874. Argynnis Euphrosyne _. Pearl-bordered Fritillary. Ruislip Wood. Vanessa Polychloros.. _... Great Tortoise Shell. " Urticæ .. $\quad$. $\quad$ Small Tortoise Shell. " Io .. $\quad$.. $\quad$.. Peacock.

" Atalanta .. .. Red Admiral.

" Cardui $\quad$.. $\quad$.. Painted Lady.

". Antiopa .. . . Camberwell Beauty.

One specimen taken.

Satyrus Egeria

Wood Argus.

Caught at Oxhey.

Satyrus Megæra .. .. Wall Butterfly.* 
Latin Name.

English Name.

Satyrus Semele

.. Grayling.

Caught at Pinner Drive.

Satyrus Janira

.. .. Meadow Brown.

, Tithonus .. .. Lesser Meadow Brown.

, Hyperanthus .. Wood Ringlet.

Caught at Oxhey Wood.

Chortobius Pamphilus

.. Small Heath.

Thecla Quercus

.. Purple Hair-streak.

Caught at Pinner Drive.

Polyommatus Phlæas

Lycæna Agon

, Agestis .. .. Brown Argus.

, Alexis . . . . Common Blue.

, Corydon .. .. Chalk Hill Blue.

Caught at Pinner Drive.
.. Small Copper.

.. Silver-studded Blue.

.. Holly Blue.*

One specimen.
Syrichthus Alveolus .. . . Grizzled Skipper.

Hesperia Sylvanus .. . . Large Skipper.

" Linea $\quad . \quad$.. $\quad$ Small Skipper.

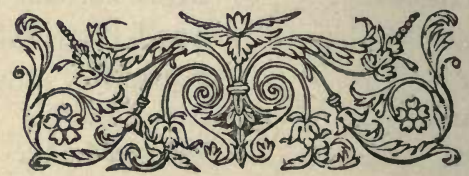




\section{SPHINXÉS, OR HAWK MOTHS.}

\section{NOCTURNI.}

Latin Name.

Smerinthus ocellatus

" Populi

English Name.

.. Eyed Hawk Moth.

.. Poplar Hawk.

Pupæ fairly common.

Smerinthus Tiliæ .. .. Lime Hawk.

Acherontia Atropos .. .. Death's Head.

Found near Roxeth.

Sphinx Convolvuli .. . . Convolvulus Hawk.

One specimen taken at Harrow.

Sphinx Ligustri . . . . Privet Hawk.

Chærocampa Elpenor $\quad$. Elephant Hawk.

Macroglossa Stellatarum .. Humming Bird.

" fuciformis .. Bee Hawk.*

One at Ruislip. (?)

\section{MOTHS.}

Latin Name.

Sesia tipuliformis Zeuzera Asculi Cossus .Ligniperda
English Name.

. Currant Clear Wing.*

. Wood Leopard.

.. Goat Moth. 
Latin Name.

English Name.

Hepialus Hectus

One at Horsington Wood.

Hepialus lupulinus .. .. Common Swift.

, Humuli .. . . Ghost Swift.

Procris Statices _. . G Green Forester.

Ruislip Wood.

Procris Globulariæ . . . B Blue-green Forester.

Near the Northwick Walk.

Zygæna Trifolii . . . . Five-spct Burnet.

Ruislip Wood.

Zygæna Filipendulæ. . . . Six-spot Burnet.

Nola cuculatella .. $\quad$.

Nudaria mundana .. . . Muslin Moth.*

Lithosia complanula $\quad$. Common Footman.

Euchelia Jacobææ .. . . Cinnabar.

Caught near the Football Field.

Euthemonia Russula

Chelonia Caja

villica

Arctia lubricipeda

" Menthastri

Liparis Chrysorrhæa

" Auriflua

, Salicis

Orgyia pudibunda

, antiqua

Trichiura Cratægi

\section{One larva at Sudbury.}

Bombyx Neustria

.. Lackey Moth.

Rubi

Quercus

Odonestis potatoria ..

.. Fox Moth.

Larræ swarming along hedges.

Lasiocampa quercifolia 


\section{GEOMETR Æ.}

Latin Name.

Uropteryx sambucata

Rumia cratægata

Venilia maculata

Metrocampa margaritata

Pericallia syringaria

Selenia illunaria

Odontopera bidentata

Crocallis elinguaria . Amphidasys prodromaria

, betularia

Hemerophila abruptaria

Cleora lichenaria

Boarmia repandata

" rhomboidaria

" consortaria

English Name.

.. Swallow Tail.

.. Brimstone.

.. Spotted Yellow.

.. Emerald.

.. Lilac Beauty.

. Common Thorn.*

.. Scalloped Hazel.

.. Scalloped Oak.

.. Oak Beauty.*

.. Pepper and Salt.*

.. Mottled Umber.

.. Lichen Moth.*

.. Mottled Beauty.

.. Willow Beauty.*

.. Pale Oak Beauty.*

Have some pupæ which I presume to be this species. Tephrosia punctulata

.. Grey Birch Moth.*

\section{One at Ruislip.}

Hemithea thymiaria

Ephyra porata

$"$ punctaria

Asthena candidata

Eupisteria heparata ..

Acidalia bisetata

" imitaria

" aversata

Timandra amataria

Cabera pusaria

Halia wavaria

Strenia clathrata

Abraxas glossulariata

Lomaspilis marginata
.. Common Emerald.

.. Maiden's Blush.*

.. Mocha Moth.*

.. White Wave.*

.. Dusky Wave.*

.. Small Wave.*

.. Small Bloodvein.*

.. Common Wave.*

.. Bloodvein.

.. White Ware.

.. The V Moth.

.. Heath Moth.*

.. Magpie.

.. Clouded Border.* 
Latin Name.

Hybernia leucophæaria defoliaria ..

Anisopteryx æscularia Cheimatobia brumata Emmelesia albulata ..
English Name.

. Spring Usher.*

.. Mottled Umber.*

.. March Moth.*

.. Winter Moth.*

.. White Rivulet.*

\section{Taken at Ruislip.}

Emmelesia decolorata

Eupethecia centaureata

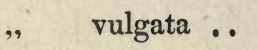

"rectangulata

Hypsipetes impluviata elutata ..

Melanthia rubiginata

$$
\text { , ocellata .. }
$$

Melanippe subtristata

$$
\begin{array}{ll}
, & \text { montanata } \\
, & \text { galiata . } \\
& \text { fluctuata }
\end{array}
$$

Anticlea badiata

$$
\text { " derivata }
$$

Coremia ferrugata ..

, unidentaria

Camptogramma bilineata Scotosia dubitata Cidaria miata

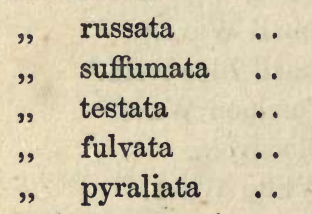

\section{Eubolia mensuraria ..} Tanagra chærophyllata
.. Sandy Rivulet.*

. . Lime-specked Pug.*

. Common Pug.*

. Green Pug.*

. May Highflyer.

. July Highflyer.

. Blue-bordered Carpet.

.. Purple-bar.

. Common Carpet.

. Silver Carpet.

. Galium Carpet.

. Garden Carpet.

.. Shoulder-stripe.*

. .

. Red Carpet.*

. . Single-dotted Carpet.*

.. Yellow Shell.

.. The Tissue.

.. Green Carpet.

.. Mottled Carpet.

. Water Carpet.

*

.. Barred Yellow.*

.. Barred Straw.

.. Small Mallow.

.. Sweep.

On the Railway Banks. 


\section{DREPANUL $Æ$.}

Latin Name.

English Name.

Platypteryx Hamula

One at Oxhey.

Cilix spinula.. . . . . Goose Egg.*

\section{PSEUDO BOMBYCES.}

Dicranura vinula furcula

Pygæra bucephala Ptilodontis palpina

Notodonta Camelina

\section{One pupa at Headstone.}

. Puss Moth.

.. Kitten Moth.

.. Buff-tip.

.. Pale Prominent.*

.. Coxcomb Prominent.* dictæa .. .. Swallow Prominent.

One specimen caught at Roxeth. Diloba cœruleocephala .. Figure of Eight.

\section{NOCTU Æ.}

Thyatira derasa $\quad$. $\quad$.. Buff Arches.

" Batis .. .. Peach Blossom.

Found at Roxeth.

Bryophila perla

Bishop Moth.*

On old walls.

Acronycta tridens .. . . Dark Dagger.

$\begin{array}{lllll} & \text { Psi } & \ldots & \ldots & \text { Grey Dagger. } \\ , & \text { Aceris } & \text {.. } & \ldots & \text { Sycamore.* }\end{array}$

Leucania pallens $\quad$. $\quad$.. Common Wainscot.

" impura .. .. White Wainscot.*

Nonagria Typhæ .. .. Bullrush Moth.*

Pupæ at the Brickfield Ponds.

Hydræcia nictitans .. . . Ear Moth.*

Hydræcia micacea .. . . Rosy Rustic.

Axylia putris _. .. Flame Moth.

Xylophasia rurea $\quad . \quad \ldots$ Clouded-bordered Brindle.

" lithoxylea .. Light Arches. 
Latin Name.

Xylophasia Polyodon

Hepatica

Neuria Saponariæ

Cerigo Cytherea

Luperina testacea

Mamestra Brassicæ ..

Persicariæ

Apamea basilinea

" oculea

Miana Strigilis

„fasciuncula

Grammesia trilinea ..

Caradrina Morpheus..

, blanda ..

\section{" cubicularis}

Agrotis segetum

, Exclamationis

Triphæna fimbria

Triphæna Janthina ..

", $\quad$ orbona..

Noctua plecta

$$
\text { , C. nigrum .. }
$$

" xanthographa Tæniocampa gothica Anthocelis lunosa Xanthia Citrago

Xanthia Cerago

One at Sugar.

\section{One at Sugar.}

Cosmia trapezina

" affinis
. Dunbar.

\section{English Name.}

.. Dark Arches.

.. Clouded Brindle.

.. Bordered Gothic.

. Straw Underwing.

. Flounced Rustic.*

. Cabbage Moth.

. . Dot Moth.*

.. Shoulder-knot.

.. Common Rustic.

.. Marked Minor.

. Barred Minor.*

. Triple Lines.

.. Bordered Rustic.

.. Mottled Willow.*

.. Common Dart.

. Heart and Dart.

. Broad-bordered Yellow

Underwing.

.. Lesser Broad-bordered.

. . Lesser Yellow Underwing

. . Large Yellow Underwing

. Flame-shoulder.

. Setaceous Hebrew

Character.

.. Square Spot.

. Hebrew Character.

. Lunar Underwing.

. Brown Pinion Spot. 
Latin Name.

Cosmia diffinis

Polia flavicincta

Miselia Oxyacanthæ. .

Phlogophora meticulosa

Euplexia lucipara ..

Hadena dentina

, oleracea
, Genistæ

English Name.

.. White Pinion Spot.

-. Ranunculus Moth.

. Green Brindled Crescent.

.. Angle Shades.

. Small Angle Shades.

. Common Shears.*

. Bright line Brown Eye.

.. Broom Moth.

One on a paling.

Cucullia umbratica Heliodes Arbuti Anarta Myrtilli

Shark Moth.

. Least Yellow Underwing.

. Beautiful Yellow Underwing.

Found at Oxhey Wood.

Brephos Parthenias ..

Found at Roxeth.

Abrostola Urticæ triplasia

Plusia Chrysitis

" Iota

Gamma

Gonoptera Libatrix .. Amphipyra pyramidea

Mania typica " maura

Catocala Fraxini
.. Spectacle Moth.

. Dark Spectacle Moth.

.. Burnished Brass.

.. Golden Y.

.. Silver Y.

.. Herald Moth.

.. Copper Underwing.*

.. Gothic.*

. . Old Lady.

.. Clifden Nonpareil.

One specimen taken at Pinner.

Catocala nupta Euclidia Mi ..

", glyphica

Both species at Ruislip.

Aventia flexula

.. Red Underwing.

.. Shipton Moth.*

.. Burnet Companion.*

.. Beautiful Hooktip.*

One at Oxhey Wood.

Hypena proboscidalis

.. The Snout. 



\section{INDEX TO FLORA.}

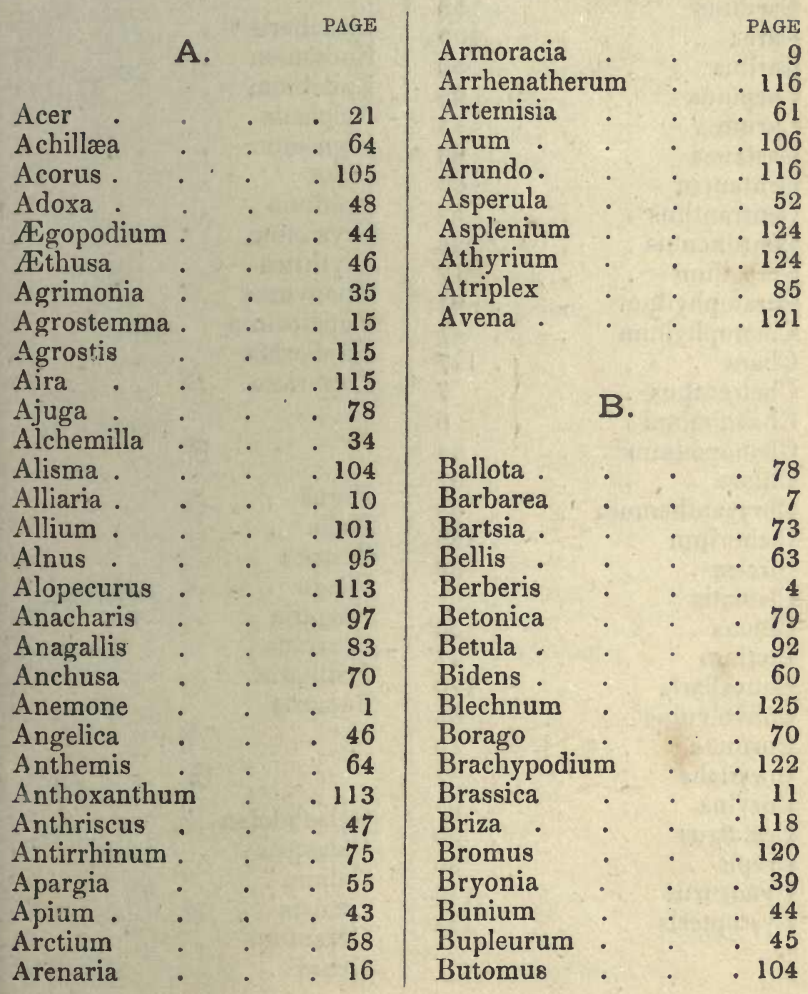




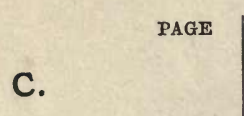

Calamintha . . 80

Caltha . . 44

Calystegia . . . 68

Callitriche . . 90

Calluna. . . . 66

Camelina . . . 11

Campanula . . . 65

Capsella . . . 10

Cardamine . . . 8

Carduus . . 58

Carex . . 109

Carlina . . . 59

Carpinus . . . 95

Carum . . . . 44

Castanea . . . 95

Centaurea . . . 60

Centranthus . . 52

Centunculus . $\quad .128$

Cerastium . . . 17

Ceratophyllum . . 91

Chærophyllum . . 48

Chara . . 127

Cheiranthus . . 7

Chelidonium . . 6

Chenopodium . . 84

Chlora . . . 67

Chrysanthemum . . 63

Cichorium . $\quad 128$

Circæa . . . 38

Clematis . . . 1

Cnicus . . . 59

Conium . . . 47

Convallaria . $\quad .129$

Convolvulus . . . 68

Cornus . . . . 49

Corydalis . . . 7

Corylus . . . 95

Cratægus . . . 36

Crepis . . . . 56

Cynosurus . . . 119

Cystopteris . . . 124
PAGE

Dactylis . . . 119

Daphne . . . 88

Datura . . . 71

Daucus. . . . 48

Digitalis . . . 75

Dipsacus . . . 53

Draba . . . 9

Drosera . . . 14

E.

Eleocharis . . .108

Endymion . . 100

Epilobium . . 37, 128

Epipactis . . . 99

Equisetum . . . 126

Erica . . . 65

Erodium . . . 22

Erysimumı . . 10

Erythræa . . . 67

Euonymus . . . 23

Eupatorium . . . 60

Euphorbia . . . 89

Euphrasia . . . 73

\section{F.}

Fagus

Fedia

Festuca

Filago .

Fragaria

Fraxinus

Fritillaria

Fumaria

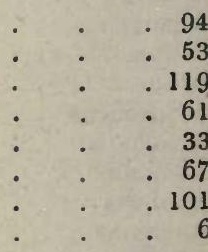

G.

Galeobdolon . . 79

Galeopsis : . $7 \varepsilon$

Galium . . . 50

Genista. . . 25

Geranium : $: 21$

Geum . . . 31 


\section{INDEX TO FLORA.}

\begin{tabular}{|c|c|c|c|c|c|}
\hline Glaucium & & $\begin{array}{r}\mathrm{PAGE} \\
\quad 6\end{array}$ & & L. & PAGE \\
\hline Glechoma & & . 80 & & & \\
\hline Glyceria & . & .117 & Lactuca & . & . 55 \\
\hline Gnaphalium & & . 61 & Lamium & . & 79,128 \\
\hline & & & Lapsana & & \\
\hline & & & Lastrea . & . & . 124,129 \\
\hline & H. & & Lathyrus & . & - 29 \\
\hline abenaria & & 98,129 & Lemna . & & $\begin{array}{r}106 \\
57\end{array}$ \\
\hline Hedera. & & $\begin{array}{l}1 \\
-48\end{array}$ & $\begin{array}{l}\text { Leontodon } \\
\text { Lepidium }\end{array}$ & : & .10 \\
\hline Helianthemur & & . 12 & Ligustrum & $\cdot$ & 66 \\
\hline Helleborus . & . & 4,127 & Linaria. & . & . 75 \\
\hline Helminthia & . & . 54 & Linum & & 18 \\
\hline Helosciadium & & . 43 & Listera . & . & . 98 \\
\hline Heracleum & . & . 47 & Lithospermur & & . 69 \\
\hline Hesperis & & - 9 & Littorella & . & 84 \\
\hline Hieracium & . & . 57 & Lolium & . & . 122,129 \\
\hline Hippuris & . & .128 & Lonicera & . & . 50 \\
\hline Holcus . & . & .116 & Lotus & & \\
\hline Hordeum & & .121 & Luzula & & . 103 \\
\hline Hottonia & . & . 82 & Lychnis & & . 15 \\
\hline umulus & . & . 91 & Lycopus & & . 76 \\
\hline Hydrocharis & & . 97 & Lysimachia & & . 82 \\
\hline Hydrocotyle & & . 43 & Lythrum & & . 39 \\
\hline Hyoscramus & & $\therefore 71$ & & & \\
\hline
\end{tabular}

Hyoscyamus . . . 71

Hypericum • . 19

Hypochæris . . 55

\section{I.}

Ilex . . . . 66

Impatiens . . . 23

Inula $\quad \cdot \quad \cdot \quad \cdot 63$

Iris . . . 99

J.

Jasione . . . $\quad 65$

Juncus . $\quad .102$

K.

Knautia
M.

Malva • _ . $\quad 19$

Matricaria . . . 64

Meconopsis . . 6

Medicago : : . 25

Melampyrum . $\cdot 74$

Melica . . . 116

Melilotus : : . 26

Mentha. . . 77

Mercurialis . . 89

Mespilus . . . 36

Milium . . . 114

Molinia. . . . 116

Montia. . . 40

Myosotis : . . 69

Myosurus . . . 2

Myriophyllum . . 39 


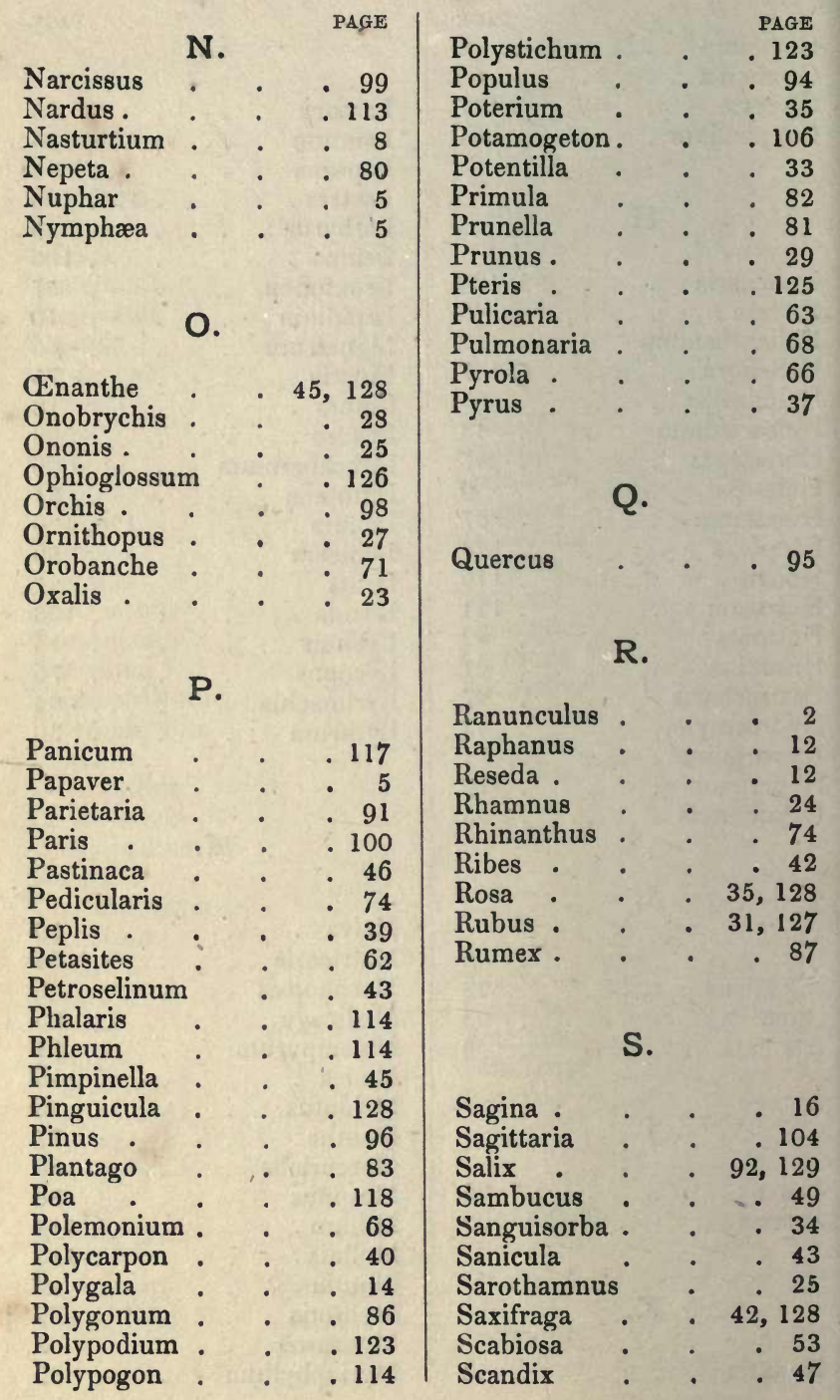




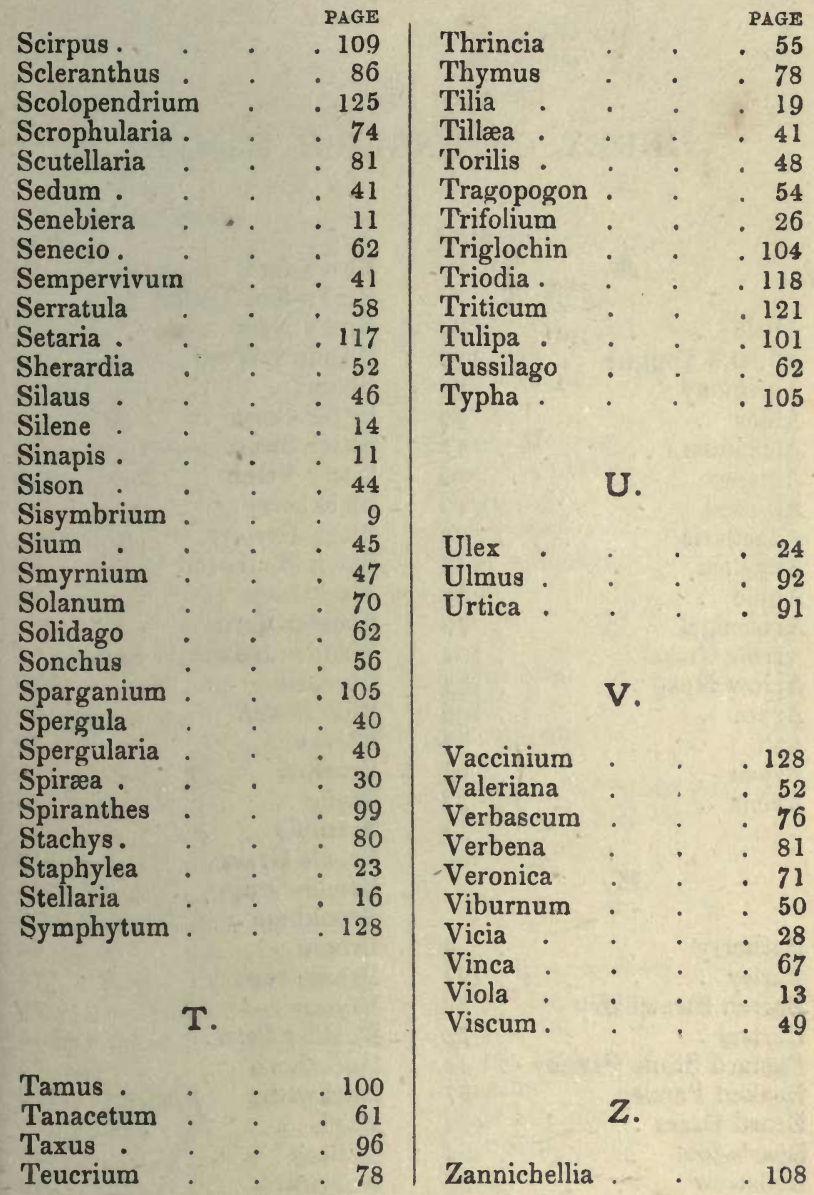




\section{INDEX OF ENGLISH NAMES.}

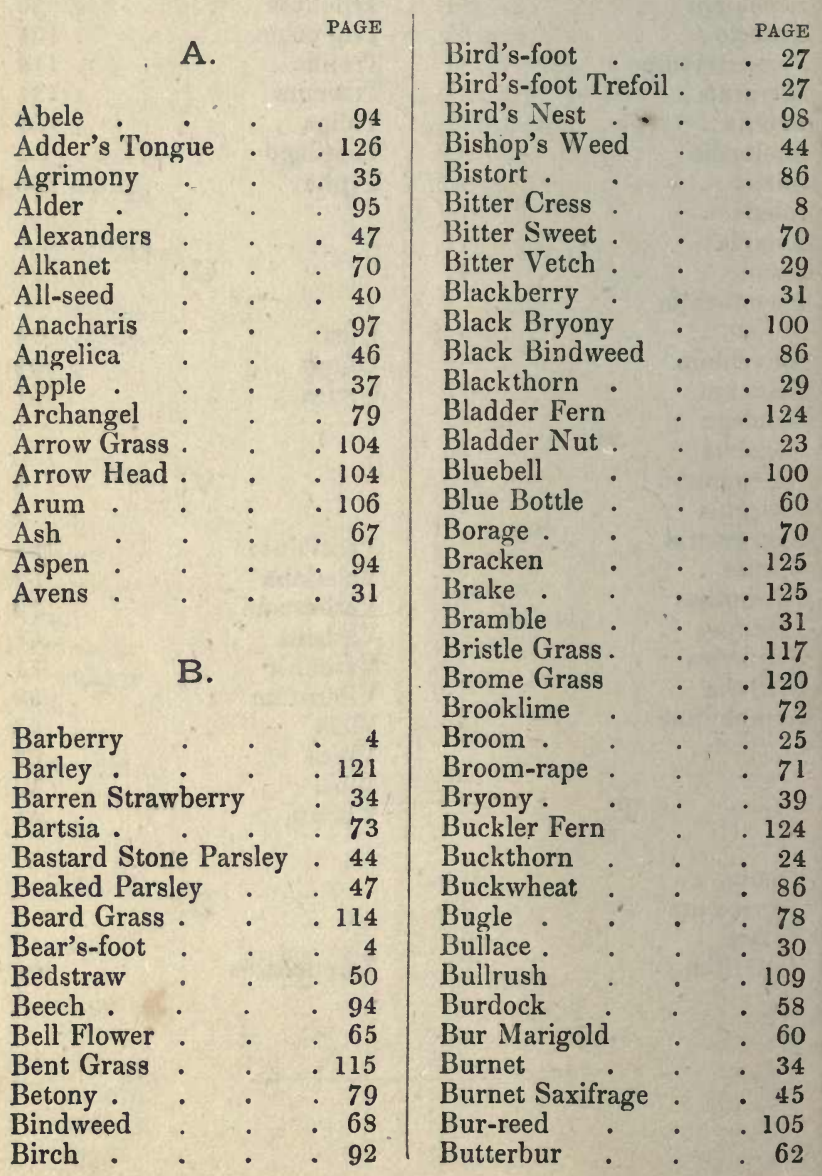




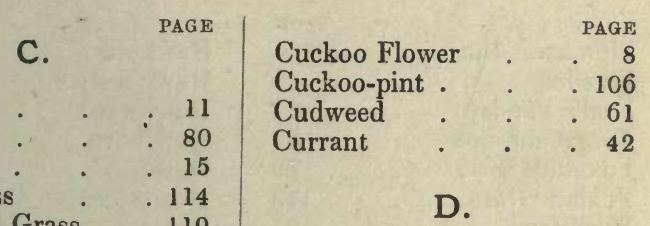

Cabbage . . 11

Calamint $\quad \therefore \quad \therefore 80$

Campion . . . 15

Canary Grass . . 114

Capon's Tail Grass $\quad .119$

Caraway . . . 44

Carline Thistle . . 59

Carrot . . . 48

Catchfly : . . 14

Cat-mint . . 80

Cat's Ear . . . 55

Cat's Tail . . . 105

Cat's Tail Grass . . 114

Celandine . . . 6

Celery . . . . 43

Centaury . : . 67

Chamomile . . 64

Chara . . . 127

Charlock . . . 12

Chequered Daffodil . 101

Cherry . . . . 29

Chervil . . . 48

Chestnut . . . 95

Cinque-foil . . . 33

Cleavers $\quad . \quad 51$

Clematis . . . 1

Clover . . . . 26

Club Rush : . 109

Cock's-foot Grass . 119

Coleseed . . . 11

Colt's-Foot . . . 62

Common Bladder-nut . 23

Corn Cockle . . . 15

Cornel . . $\quad 49$

Corn Marigold : . 63

Corn Mint . . . 77

Corn Salad . . . 53

Corydalis

Couch Grass . $\quad .121$

Cow Parsnep. . . 47

Cowslip

Cow Wheat. . 74

Crane's Bill . . . 21

Crowfoot
Daffodil . $\quad$. 99

Daisy - . . . 63

Dame's Violet . . 9

Dandelion . . . 57

Danewort . . . 49

Dead Nettle . . . 79

Dock . . . . 87

Dog's Mercury . . 89

Dog's-tail Grass . 119

Dogwood . . . 49

Duckweed . . . 106

Dyer's Rocket . . 12

E.

Earth Nut . . . 44

Elder . . . . 49

Elecampane . . 63

Elm . . . 92

Enchanter's Nightshade. 38

Everlasting Pea . . 29

Eye Bright . . . 73

\section{F.}

False Brome Grass $\quad .122$

False Oat Grass . $\quad .116$

Featherfoil . . 82

Fescue Grass $\quad . \quad 119$

Feverfew . . . 64

Field Madder . $\quad 52$

Figwort . . . 74

Filago . . . 61

Fir . . . . 96

Flag . . . 99

Flax . . . 18

Flea Bane . . . 63

Fleawort . . 62

Flower-de-Luce . $\quad$. 99 


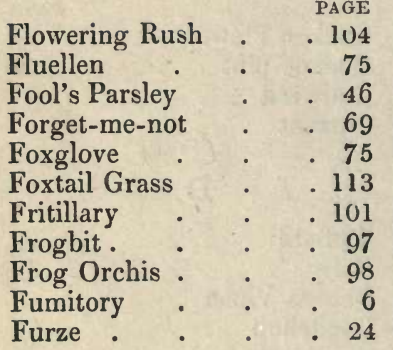

\section{G.}

Garden Cress

Garlick .

Garlic Mustard

Germander

Gipsywort

Goat's Beard. . . 54

Golden Rod . • . 62

Goldilocks • • 3

Gold of Pleasure . . 11

Good King Henry • 85

Gooseberry . . 42

Goose-foot · . 84

Goose Grass . 33, 51

Gorse . . . 24

Gout Weed — . 44

Grass Vetch . . . 29

Green Weed . • . 25

Gromwell . . . 69

Ground Ivy . $\quad$. $\quad$. 80

Groundsel . . . 62

Guelder Rose . . 50

\section{H.}

Hair Grass . . . 115

Hard Fern . . . 125

Harebell . . . 65

Hare's Ear . . . 45

Hart's Tongue . 125

Haver.
Hawkbit

Hawk's Beard . . 56

Hawkweed . . . 57

Hawthorn . . . 36

Hazel . . . . 95

Heartsease . . . 13

Heath . . . 65

Heather . . 66

Heath Grass . . . 118

Hedge Mustard . . 9

Hedge Parsley . . 48

Hellebore . . . 4

Helleborine . . . 99

Hemlock . . . 47

Hemp . . . . 91

Hemp Agrimony . . 60

Hemp Nettle. . . 78

Henbane . . 71

Herb Paris . . . 100

Herb Robert . . . 22

Herb Twopence . . 83

Hog Weed . . . 47

Holly . . $\therefore 66$

Honeysuckle . 50

Hooded Bindweed . $\quad$. 68

Hop . . . . 91

Horehound . . . 78

Hornbeam . . . 95

Horned Pondweed 108

Horned Poppy . . 6

Hornwort . . . 91

Horse Radish . . 9

Horsetail . . 126

House Leek . . . 41

\section{I.}

Iris

Ivy

J.

Jacob's Ladder . . 68 


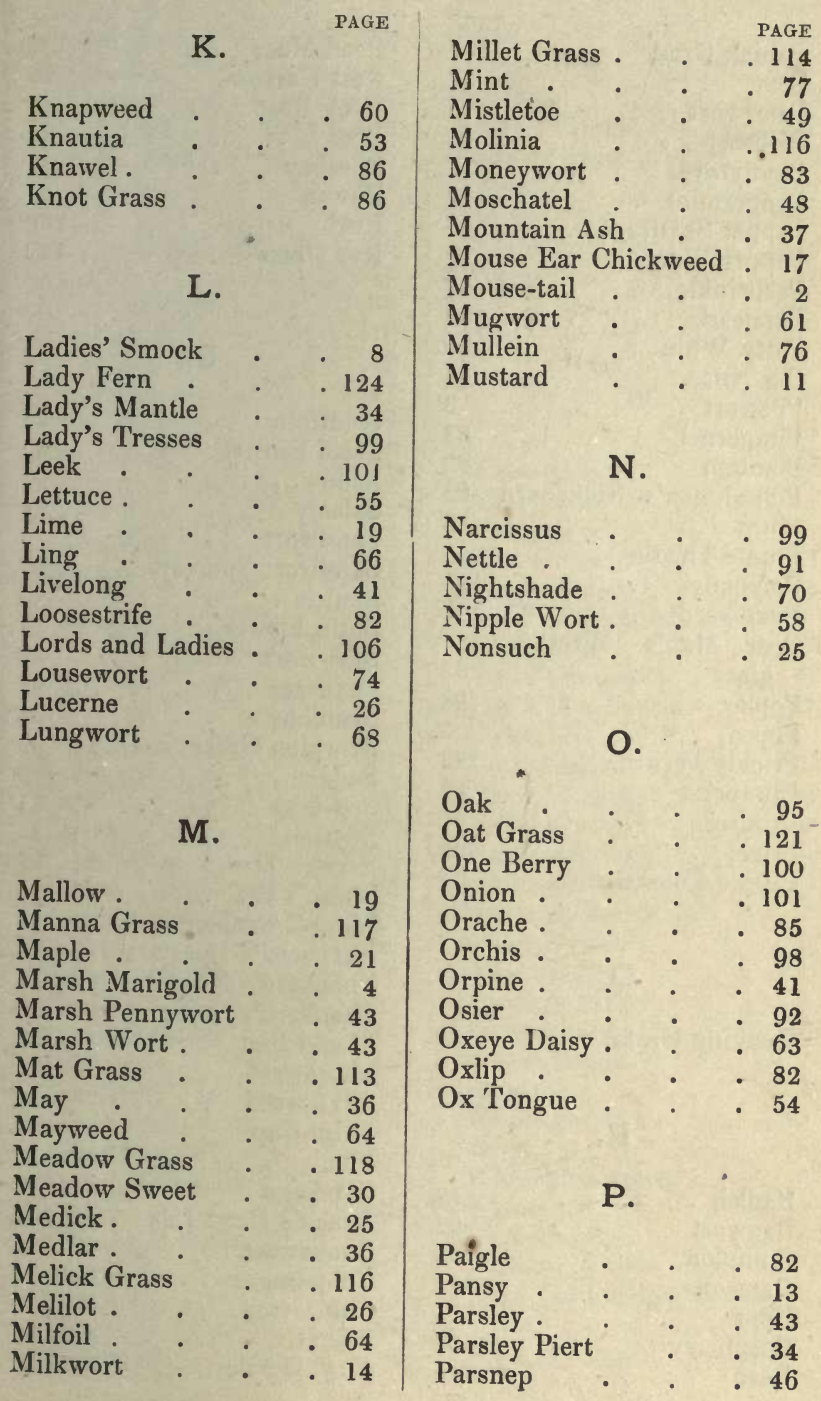




\begin{tabular}{|c|c|c|c|}
\hline \multicolumn{2}{|l|}{ Panick Gras } & & 117 \\
\hline Pear & • & & 37 \\
\hline Pearlwort & & & G \\
\hline ellitory & & & 9 \\
\hline ennyroyal & - & & \\
\hline eppermint & & & \\
\hline Saxifr & rag & & \\
\hline Vort & & & \\
\hline nkle & . & & 67 \\
\hline caria & & & \\
\hline etty Whin & • & $\cdot$ & 25 \\
\hline ig Nut & & & 44 \\
\hline ort & & . & \\
\hline ernel & & & 8 \\
\hline lantain & & & 8 \\
\hline hm & & & \\
\hline Plu & & & \\
\hline & & & \\
\hline & . & & 12 \\
\hline & & & \\
\hline
\end{tabular}

Poor Man's Weatherglass . . . . 83 Poplar • . . . 94

Poppy . . . . 5

Prickly Fern . . . 123

Primprint . . 66

Primrose . . $\quad 82$

Privet . . . 66

Purple Loosestrife . $\quad$. 39

Q.

Quaking Grass . 118

R.

Radish .

Ragwort

Rampion

Ramsons

Rape.

Raspberry

Reed
PAGE

Reed Mace . . . 105

Rest Harrow . . . 25

Rock Rose . . . 12

Rose . . . . 35

Rosebay . . . 37

Rowan . . . . 37

Rush . . . . 102

Rye Grass . $\quad$. 122

S.

Saintfoin . . 28

Salad Burnet. . $\quad 35$

Sallow . . . . 92

Salsafy . . . . 54

Sandwort . . . 16

Sandwort Spurrey • . 40

Sanicle . . . . 43

Satin Flower . 17

Saw-wort . . . 58

Saxifrage . . . 42

Scabious . . . 53

Scorpion Grass _ . 69

Sedge . . . 109

Self-heal . . . 81

Septfoil . . . 34

Service Tree . . . 37

Sheep's Bit . . . 65

Sheep's Scabious . . 65

Shepherd's Eyeglass . 83

Shepherd's Needle 47

Shepherd's Purse . . 10

Shield Fern . . 123

Shoreweed . . . 84

Silverweed . . . 33

Skull Cap . . . 81

Sloe . . . 29

Smallage . . . 43

Snake's Head Lily. $\quad 101$

Snakeweed . . . 86

Snapdragon . . . 75

Soft Grass . . $\quad .116$

Sorrel .. . . . 87

Sow Thistle . . . 56 


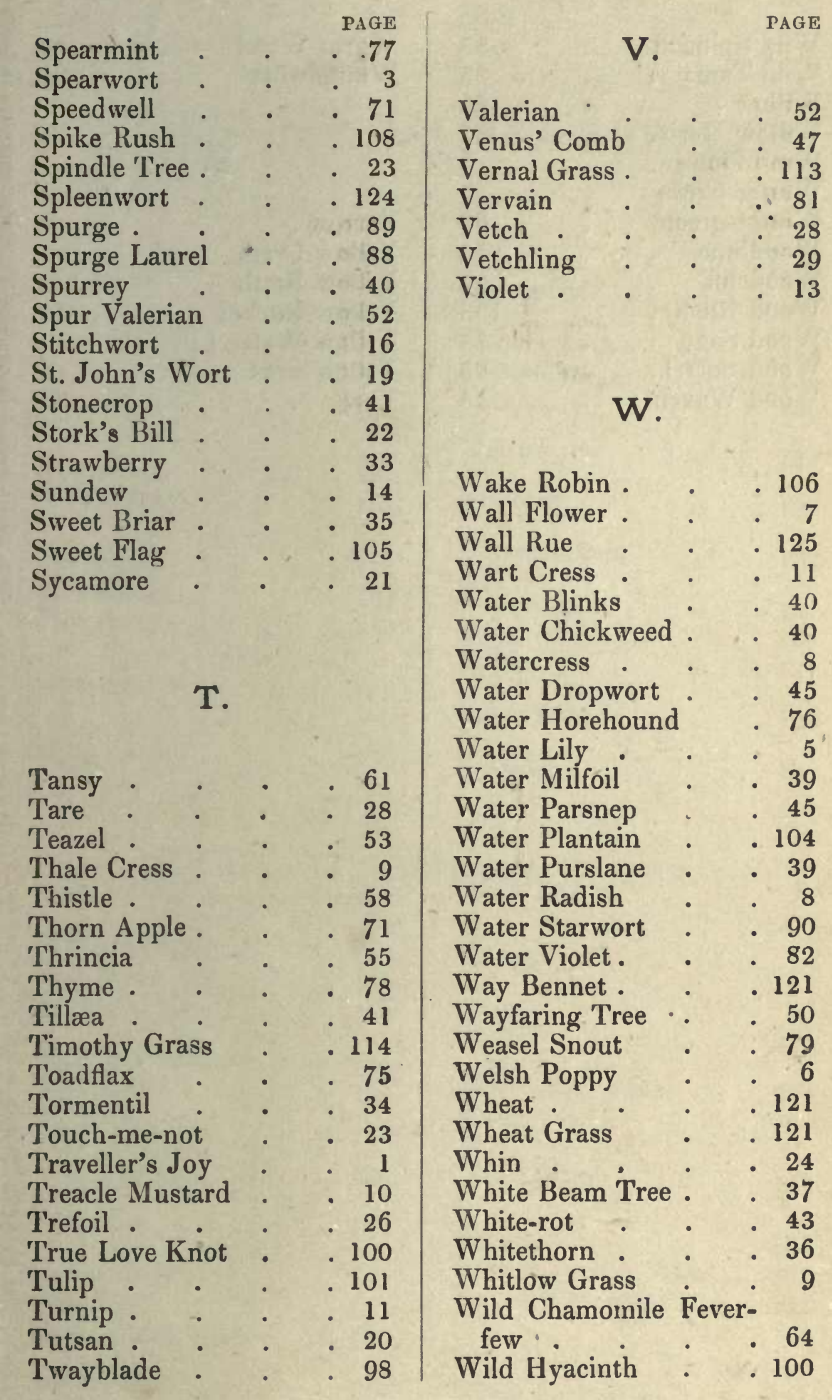


INDEX OF ENGLISH NAMES.

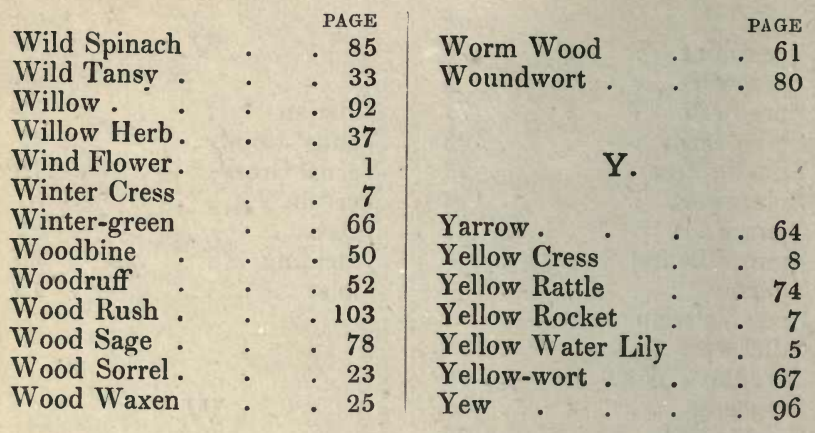




\section{INDEX TO MOSSES.}

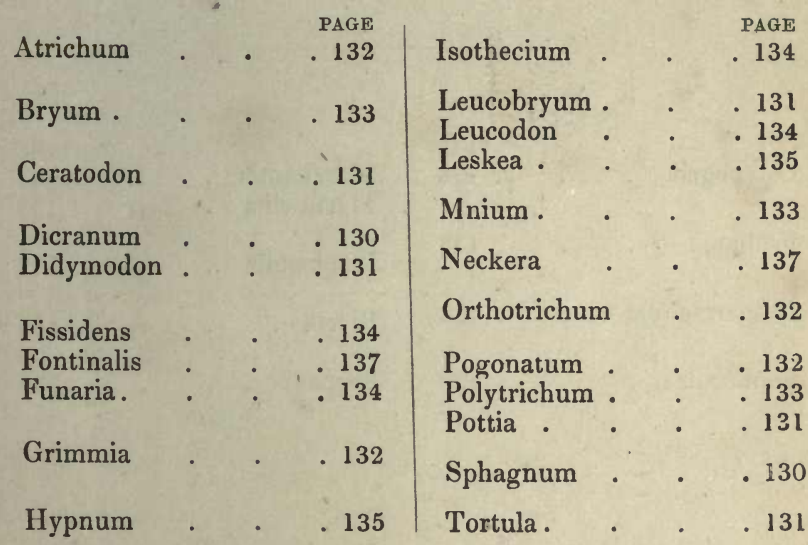

\section{INDEX OF ENGLISH NAMES.}

\begin{tabular}{|c|c|c|c|}
\hline & PAGE & & PAGE \\
\hline $\begin{array}{l}\text { Bearded Moss } \\
\text { Bog Moss }\end{array}$ & $\begin{array}{r}132 \\
130\end{array}$ & Leskea & • 135 \\
\hline Bristle Moss & 132 & Neckera & 137 \\
\hline $\begin{array}{l}\text { Cleft Tooth Moss } \\
\text { Cord Moss. }\end{array}$ & $\begin{array}{r}134 \\
\cdot \quad 134\end{array}$ & $\begin{array}{l}\text { Pale Tooth Mo } \\
\text { Pottia. }\end{array}$ & $\begin{array}{l}134 \\
. \quad 131\end{array}$ \\
\hline $\begin{array}{l}\text { Feather Moss } \\
\text { Fork Moss . }\end{array}$ & $\begin{array}{l}135 \\
\cdot \quad 130\end{array}$ & Screw Moss & 131 \\
\hline Grimmia . & - 132 & Thread Moss & . 133 \\
\hline $\begin{array}{l}\text { Hairless Moss } \\
\text { Hair Moss. } \\
\text { Horn Tooth Moss }\end{array}$ & $\begin{array}{r}132 \\
: \begin{array}{l}133 \\
131\end{array}\end{array}$ & $\begin{array}{l}\text { Thyme Thread Mo } \\
\text { Twin Tooth Moss }\end{array}$ & $\begin{array}{l}133 \\
131\end{array}$ \\
\hline Isothecium & . 134 & $\begin{array}{l}\text { Water Moss } \\
\text { White Fork Moss }\end{array}$ & $\begin{array}{l}137 \\
0 \quad 131\end{array}$ \\
\hline
\end{tabular}




\section{INDEX TO LIVERWORTS.}

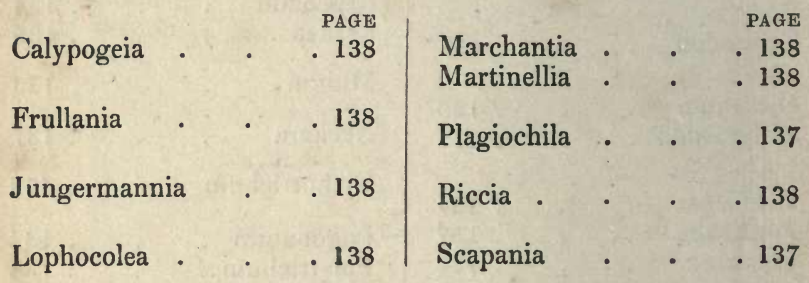





\section{DAY USE \\ RETURN TO DESK FROM WHICH BORROWED BIOLOGY LIBRARY}

TEL. NO. 642-2531

This book is due on the last date stamped below, or on the date to which renewed.

Renewed books are subject to immediate recall.

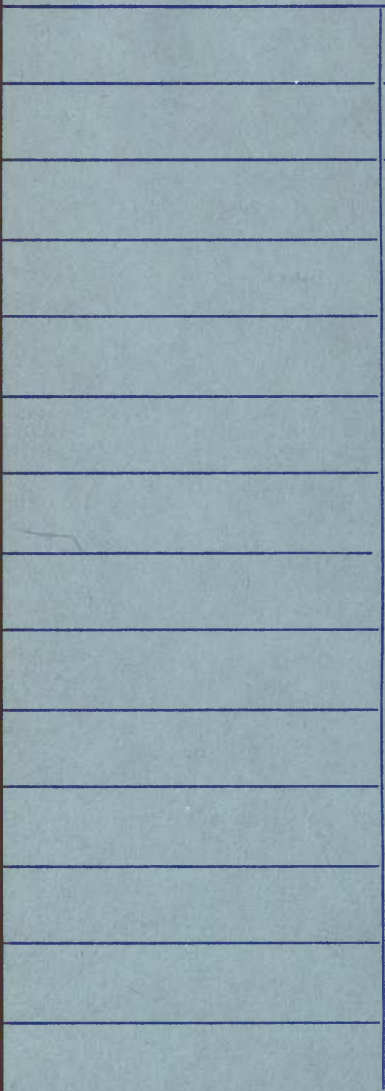

LD 21A-15m-2,'69

(J6057s10) $476-\mathrm{A}-32$
General Library

University of California Berkeley 
U.C. BERKELEY LIBRARIES

|| || ||

Сロㅁl15025 


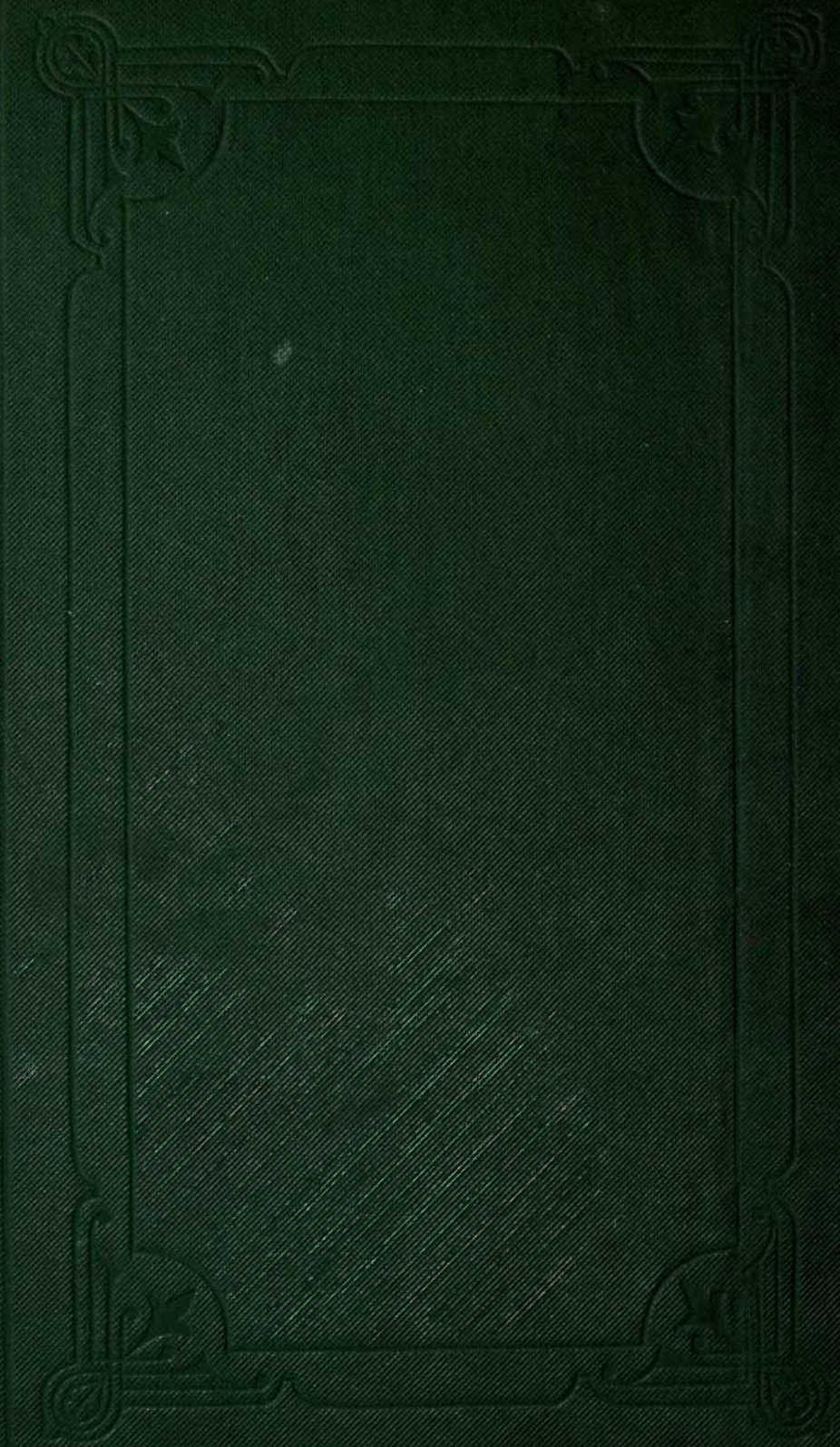

